\title{
Nutrient response efficiency, tree-microbe competition for nutrients and tree neighborhood dynamics in a mixed-species temperate deciduous forest in central Germany
}

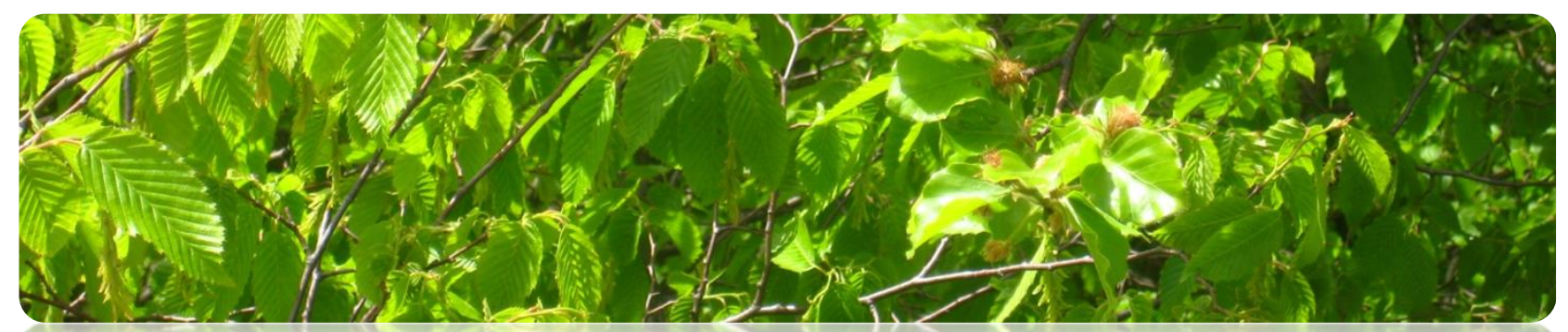

Dissertation zur Erlangung des Doktorgrades

der Fakultät für Forstwissenschaften und Waldökologie

der Georg-August-Universität Göttingen

\author{
vorgelegt von \\ Marcus Schmidt
}

geboren in Suhl 
1. Gutachter: Prof. Dr. Edzo Veldkamp

2. Gutachter: Prof. Dr. Christian Ammer

Betreuer: $\quad$ Prof. Dr. Edzo Veldkamp \&

Dr. Marife D. Corre,

Abteilung Ökopedologie der Tropen und Subtropen,

Georg-August-Universität Göttingen 


\section{Table of contents}

$\begin{array}{ll}\text { Zusammenfassung } & \text { page } 7\end{array}$

$\begin{array}{ll}\text { Summary } & \text { page } 9\end{array}$

INTRODUCTION $\quad$ page 11

Part A-General dynamics in temperate deciduous forests $\quad$ page 11

Part B - Recent research and hypotheses $\quad$ page 15

\section{CHAPTER 1}

Tree species diversity effects on productivity, soil nutrient availability and

nutrient response efficiency in a temperate deciduous forest

page 21

\section{CHAPTER 2}

Tree-microbial biomass competition for nutrients in a temperate deciduous

forest, central Germany

page 47

\section{CHAPTER 3}

Tree neighborhood dynamics of beech, oak, hornbeam and lime

in a temperate deciduous forest

page 77

SYNTHESIS

page 95

Danksagung

page 99

Curriculum Vitae

page 101 


\section{Zusammenfassung}

In den meisten Ländern Mitteleuropas gilt weniger als ein Prozent des verbleibenden Laubwaldes als ungestört und temperierte Wälder sind Herausforderungen wie Arteninvasion, Klimawandel und steigender Stickstoff(N)-Deposition ausgesetzt. In der Vergangenheit wurde gezeigt, dass hohe N-Einträge N-Limitierungen verringern, Phosphor(P)aufnahme behindern und P-Mängel in der Buche auslösen können. Die Artendiversität von Bäumen kann die Bestandsproduktivität durch die Prozesse Komplementarität und Facilitation (Wachstumserleichterung) erhöhen, wenn diese einen wachstumslimitierenden Nährstoff betreffen. Ein Schlüsselprozess im Nährstoffkreislauf ist der Weg von Nährstoffen durch die mikrobielle Biomasse während der Dekomposition. Es wurde gezeigt, dass die mikrobielle Biomasse um N bspw. mit Buchen und um P mit tropischen Moorpflanzen konkurriert. Die Buche ist eine sehr konkurrenzfähige Baumart in temperierten Waldökosystemen aber kann von der Eiche in trockenen Bereichen übertrumpft werden, während Hainbuche und Linde eine geringere Rolle spielen. Eichen erfahren jedoch in der jüngsten Vergangenheit in europäischen Wäldern einen Rückgang, der womöglich auf hohe N-Einträge zurückzuführen ist.

Für diese Arbeit untersuchten wir die Nährstoff-, Konkurrenz- und strukturelle Dynamik eines unbewirtschafteten, sehr naturnahen Laubwaldes in Mitteldeutschland, der aus Buche (Fagus sylvatica), Eiche (Quercus petraea und Quercus robur), Hainbuche (Carpinus betulus) und Linde (Tilia cordata und Tilia platyphyllus) aufgebaut ist. Unsere Ziele waren (1) zu erforschen, ob Komplementarität und/oder Facilitation die Produktivität in diesem Waldökosystem erhöht, (2) festzustellen, ob es Konkurrenz um die Nährstoffe N, P und K zwischen Bäumen und mikrobieller Biomasse gibt und, (3) die Nachbarschaftsdynamik der genannten Baumarten zu untersuchen und herauszufinden, ob der Eichenrückgang mit hoher N-Deposition einhergeht.

In Beständen einer Art sowie verschiedenen Mischbeständen aus je drei Arten ermittelten wir Biomasseproduktion und Nährstoffverfügbarkeit. Nährstoffnutzungseffizienzkurven (Nährstoffnutzungseffizienz = Biomasseproduktion pro verfügbare Nährstoffe) wurden genutzt um festzustellen, ob ein bestimmter Nährstoff das Baumwachstum limitiert. Die jährliche NettoNährstoffveränderung wurde in einer Laubbeutel-Studie als Differenz zwischen ursprünglichem und verbleibendem Nährstoffgehalt des sich zersetzenden Laubfalls nach einem Jahr kalkuliert. Die Nährstoffresorptionseffizienz berechneten wir über die Ermittlung der N-, P- und Kalium(K)Konzentrationen in sonnenexponierten Blättern und im gefallenen Laub. Die Nachbarschaftsdynamik von Bäumen wurde über die Durchmesserverteilung, überirdische Holzbiomasse für jede Artenkombination 
sowie eine Polygon-Abschätzung von Wachstumsräumen erforscht. Zusätzlich wurde eine durchmesserbasierte nearest neighbor(nächster-Nachbar)-Analyse für Baumpaare durchgeführt. Ein Geographisches Informationssystem (GIS) wurde genutzt um Wachstumsraum-Polygone zu erstellen und nächste Nachbarn zu bestimmen.

Auf Einzelbaum-Level, ermittelt durch einen Nachbarschaftsansatz, waren relative Wachstumsraten von Buchen im Einzelbestand geringer als in der Mischung mit Linde und Hainbuche während das Wachstum von Linde im Einzelbestand größer war als in Mischung mit Buche und Eiche. Die Nährstoffnutzungseffizienzkurve für Buche zeigte optimale P- und K-Nutzungseffizienz für die Art in Mischbeständen, während sie in Einzelbeständen P- und K-limitiert war. Während die jährliche NettoNährstoffveränderung in sich zersetzendem Blattlaub die Verfügbarkeit von P und K im Boden beeinflusste, war dies für N nicht der Fall. Resorptionseffizienzen von N, P und $\mathrm{K}$ hingen negativ mit der jährlichen Netto-Nährstoffveränderung zusammen. In unserer Studie zur Nachbarschaftsdynamik von Bäumen fanden wir heraus, dass intraspezifische nearest neighbors gleiche Durchmesser aufwiesen und ihren Durchmesser gleichzeitig mit dem des Nachbarn vergrößerten. Im Gegensatz dazu waren die Durchmesser von interspezifischen nearest neighbors im Allgemeinen unterschiedlich und der Durchmesser des Nachbarn verringerte sich mit zunehmendem Durchmesser des Zielbaums. Eichen konnten ihren Wachstumsraum mit zunehmendem Durchmesser nicht vergrößern, aber dominierten ihre nearest neighbor über die Größe.

Unsere Ergebnisse zeigten, dass im untersuchten Waldökosystem Nährstofflimitierungen artabhängig waren und dass die Nutzung von Nährstoffnutzungseffizienz und Nachbarschaftsansatz geeignete Mittel sind, den Einfluss einzelner Baumarten auf die Produktivität einer Art im Rein- und Mischbestand zu ermitteln - so wie die beobachtete Facilitation der Buche im Mischbestand. Diese Werkzeuge stellen eine wichtige Basis zur verbesserten Bewirtschaftung typischer temperierter Mischwälder dar. Wir schlussfolgerten weiterhin, dass Konkurrenz zwischen mikrobieller Biomasse und Bäumen für $\mathrm{P}$ und $\mathrm{K}$ hoch, aber für $\mathrm{N}$ weniger bedeutend war, was wahrscheinlich in hoher $\mathrm{N}$-Deposition in diesem Waldökosystem begründet liegt, welche den internen N-Kreislauf entkoppelte. Die hohe NDeposition trug wahrscheinlich auch zu geringer Verjüngung der Eiche bei, während ältere Eichen in unserem Untersuchungsgebiet im Wettbewerb um Licht erfolgreich waren. Die Bestandsstruktur war charakterisiert durch stärkere interspezifische verglichen mit intraspezifischer Konkurrenz. Daraus resultierend bildeten Reinbestände aus Buche, Eiche und Linde Klimaxbestände hoher Biomasse innerhalb eines sich verändernden, kleinskaligen Mosaiks verschiedener Artenzusammensetzungen. In Reaktion auf neue Bewirtschaftungsanforderungen des Globalen Wandels sind weiterführende 
Forschungen zu Nutzungseffizienz unterschiedlicher Ressourcen für Baumarten in verschiedenen Zusammensetzungen empfehlenswert.

\section{Summary}

In most Central European countries, less than one percent of the remaining broadleaved forest is undisturbed and temperate forests face challenges such as species invasion, climate change and increased nitrogen deposition. High $\mathrm{N}$ deposition has been shown to alleviate $\mathrm{N}$ limitation, inhibit $\mathrm{P}$ uptake and cause deficiencies in leaf P status of beech. Tree species diversity may increase stand productivity in temperate forests through complementary resource use and/or facilitation of a limiting nutrient. The passage of nutrients through microbial biomass during decomposition is a key process in nutrient cycling and competition between trees and the microbial biomass has been demonstrated for $\mathrm{N}$ e.g., in beech trees and for $\mathrm{P}$ in tropical peatlands. Beech is a very competitive tree species within temperate forest ecosystems, but may in dry areas be outcompeted by oak, while hornbeam and lime play a smaller role. However, oak experiences a recent decline in European forests, possibly also related to high $\mathrm{N}$ deposition.

In this work, we explored nutritional, competitive and structural dynamics in an unmanaged, very close-to natural mixed species deciduous forest in Central Germany, comprised of beech (Fagus sylvatica), oak (Quercus petraea and Quercus robur), hornbeam (Carpinus betulus) and lime (Tilia cordata and Tilia platyphyllus). Our aims were to: (1) investigate whether complementarity and/or facilitation increase productivity in this forest ecosystem, (2) determine whether there is competition for nutrients ( $N, P$ and $K$ ) between trees and the microbial biomass and, (3) investigate tree neighborhood dynamics and whether oak declined in this forest due to high $\mathrm{N}$ deposition.

In stands of single species (mono-species stands) and in stands with different combinations of three of the tree species (mix-species stands), we measured biomass production and availability of nutrients. Nutrient response efficiency curves (nutrient response efficiency = biomass production per nutrient availability) were used to evaluate whether a specific nutrient limited tree growth. Annual net nutrient change in a litterbag study was calculated as the difference between the initial and remaining nutrient contents in the decomposing leaf litter after one year. For the calculation of nutrient resorption efficiency, we measured N, P and K concentrations in sun-exposed leaves and in leaf litterfall. Tree neighborhood dynamics were assessed by diameter distribution for each species, above-ground woody 
biomass for each species composition as well as polygon-estimation of growing spaces and diameter based nearest-neighbor analysis for tree pairs. A geographic information system (GIS) was used to create such polygons and detect nearest neighbors.

At a tree level, using a neighborhood approach, relative growth rates of beech trees in monospecies stands were smaller than when they were in mix with lime and hornbeam whereas growth of lime trees in mono-species stands was larger than in mix with beech and oak. The nutrient response efficiency curve for beech showed that beech trees in mix-species stands had optimal $\mathrm{P}$ and $\mathrm{K}$ response efficiencies whereas beech trees in mono-species stands showed $\mathrm{P}$ and $\mathrm{K}$ limitations. While net nutrient change in decomposing leaf litter influenced the availability of $\mathrm{P}$ and $\mathrm{K}$ in the soil, this was not the case for soil $\mathrm{N}$ availability. Resorption efficiencies for $\mathrm{N}, \mathrm{P}$ and $\mathrm{K}$ were negatively related to net nutrient change in decomposing leaf litter. In our study on tree neighborhood dynamics we found that in intraspecific nearest-neighborhoods, neighbors had the same $\mathrm{dbh}$ and increased their $\mathrm{dbh}$ with that of their neighbor. In contrast, in interspecific nearest neighborhoods, dbh between neighbors generally differed and neighbor dbh decreased with increasing dbh of a target tree. Oak trees were not able to increase growing space with dbh but dominated in size over their nearest neighbors.

Our results showed that in the studied forest ecosystem, nutrient limitation was speciesdependent and that using nutrient response efficiency and a neighborhood approach are useful tools in quantifying the effects of individual tree species on a species' productivity between mono- and mixspecies stands, such as an observed facilitation of beech in mixed-species stands. These tools provide important basis for improving management of typical mix-species, temperate forests. We also concluded that competition between microbial biomass and trees was strong for $\mathrm{P}$ and $\mathrm{K}$ and minor for $\mathrm{N}$, likely due to high atmospheric $\mathrm{N}$ deposition in this forest ecosystem, resulting in decoupling of the internal $\mathrm{N}$ cycle. High $\mathrm{N}$ deposition likely also contributed to little recent rejuvenation of oak trees, while older oak trees were competitive for light in our research area. Stand structure was characterized by greater intercompared to intraspecific competition. As a result, mono-species stands of beech, oak and lime formed high-biomass climax stands in a shifting small-scale mosaic of compositions. In meeting the new management demands of global change, further investigations of resource response efficiency for tree species in different species compositions are recommended. 
Introduction 


\title{
Introduction
}

\author{
Part A - General dynamics in temperate deciduous forests
}

\section{Framework of GRK 1086}

The DFG-funded research training group 1086 aims to investigate how tree species diversity affects organisms and their interaction within a temperate deciduous forest. It focuses on productivity, water- and nutrient cycling as well as ecosystem services. Besides the subprograms A (Biodiversity analysis and biotic interactions) and C (Synthesis), the thesis on hand is part of the subprogram B: biogeochemical cycles (GRK 1086).

\section{Temperate forest ecosystems - an introduction}

Temperate deciduous forests populate the intermediate climate and latitude of the Northern Hemisphere and have been heavily altered by human actions, especially land-use change (Reich and Frelich 2002). Of all Central-West Europe, today only $26 \%$ of the land is covered by forests, of which over $90 \%$ are available to forestry. Overall, about $50 \%$ consist of broadleaved forest (Köhl and San-MiguelAyanz 2002). In most countries, not even $1 \%$ of it is undisturbed and faces species invasion, climate change and increased nitrogen deposition, leading to potential alterations of species composition (Reich and Frelich 2002, EEA 2008). Temperate deciduous forests are important in many ecological and social aspects, including carbon storage, water quality, biodiversity, wood production, recreation (Reich and Frelich 2002) and microclimate (Chen et al. 1999). The Hainich study site represents unmanaged European forests with a species composition which has been found to be typical for Central Europe (Mölder 2006).

\section{Competition for water, light and nutrients}

In forest ecosystems, trees, shrubs and herbs constantly compete for resources. From the crown downward, light is reduced, so that in beech stands, e.g., $90 \%$ of the light has been found to be intercepted by leaves (Trapp 1938, as cited in Kozlowski et al. 1991). Many established parameters of competitiveness are based on light or water, such as shade creation, shade tolerance or the tolerance towards summer drought (Ellenberg and Leuschner 2010). A species may also be limited by more than 
one resource simultaneously and two co-existing species may be limited by different resources. Furthermore, resources may be unequally distributed. In the case of nutrients in temperate deciduous forests, there is spatial and temporal variation due to the seasonal addition of organic material in leaf litter fall (Crawley 1997). According to Crawley (1990), interspecific competition plays the greatest role in the population dynamics of plant communities, followed by herbivory, intraspecific competition and seed limitation.

Competition in plant communities is asymmetric, i.e., a larger plant has a greater influence on a smaller plant and vice versa, and communities are continuously changing through succession (Crawley 1990). The greater importance of inter-vs. intraspecific competition suggested by Crawley (1990) can be illustrated especially well for both beech and oak. Small oak trees need much light, which is provided by a loose crown of older trees (Ellenberg and Leuschner 2010). On opposite, older trees of beech create much shade which gives its own saplings a competitive advantage, since they are quite shade tolerant (von Wuehlisch 2008). However, higher intraspecific competition has also been shown (Röhrig et al. 2006; Begon et al. 2006).

\section{The mineral nutrients $N, P, K$, Ca and $M g$}

Mineral nutrients are acquired by plants either from minerals directly or they are mineralized. They are taken up by the roots, either through absorption as ions in the soil solution, exchange absorption or mobilization of bound nutrients (Larcher 2003). The chapters in this thesis deal with the five elements generally regarded in forest ecosystem science, namely nitrogen $(N)$, phosphorus $(P)$, potassium (K), calcium (Ca) and magnesium (Mg). $\mathrm{N}$ can be found in proteins and nucleic acids and is part of enzymes and the protoplasm. $\mathrm{N}$ deficiencies can cause, e.g., a reduction of shoot/root ratio. $\mathrm{P}$ is part of nucleotides and phytin and used in the phosphorylation. When it is deficient, reproductive processes can be delayed. $\mathrm{K}$ is important in hydration and enzyme activation, with deficiencies causing the curling of older leaf edges. Ca is used as a signaling substance so that root growth can be reduced when amounts are too low. Lastly, Mg is used in the photosynthesis and growth reduction might result from deficiencies (Larcher 2003, partly based on Finck 1969).

Species of this thesis: beech, oak, hornbeam and lime

European beech (Fagus sylvatica) plays a special role, as it - often associated with fir potentially dominates a majority of the area of Central Europe. It shades other tree species on sites where it is not too warm, cold and dry and also not too nutrient-rich (Ellenberg and Leuschner 2010). Beech prefers damp and penetrable soils (von Wuehlisch 2008). Its wood is used for furniture, fuelwood 
and pulp (von Wuehlisch 2008). Both oak species in the following studies (Quercus petraea \& Quercus robur) are ecologically similar in our research area (Ellenberg and Leuschner 2010). They grow mainly on plains, on many soils up to $1800 \mathrm{~m}$ throughout large parts of Europe. Natural regeneration can be difficult and require plantations. Q. petraea, the more apparent species in our study, can be a latesuccessional species when summers are dry. It can tolerate a wide range of ecological conditions concerning moisture and pH (Ducousso and Bordacs 2004). Therefore, oak possesses an advantage where growth of beech is diminished, namely in sites that are warm and dry, acidic or poor in nutrients, as well as subject to strong frost (Ellenberg and Leuschner 2010). Oak wood is used for ships, buildings furniture and fuelwood (Ducousso and Bordacs 2004), but is less used today due to relatively slow growth (Ellenberg and Leuschner 2010). In some parts of Europe, animals are still grazing forests with oak during mast years (Ducousso and Bordacs 2004).

The advantages of oak over beech in dryer conditions come into play on the eastern parts of the Hainich, where the following studies took place (Ellenberg and Leuschner 2010, Nationalparkverwaltung Hainich 2008). On such sites, oak-hornbeam (Carpinus betulus) mixed forests with more or less beech can establish themselves (Ellenberg and Leuschner 2010). The fourth species, found solely in mixed stands in Central Europe, is lime (at Hainich mostly Tilia cordata, Rajendra 2009). It is drought-resistant, tolerates low nutrient levels and prefers sandy and loamy sites (Svejgaard Jensen 2003). While hornbeam is mostly used for firewood (Ellenberg and Leuschner 2010) use of lime can additionally be found in carving and honey production. In our culture, lime is also a landscape tree and recreational species (Svejgaard Jensen 2003).

\section{Results from previous, related studies at Hainich}

Several studies on nutrient cycling were previously conducted within the framework of the DFG research training group 1086 at Hainich forest. One study found species mixing important in maintaining soil quality: leaf litterfall of mixed species compared to beech stands increased N, Ca and Mg in the soil (Guckland 2009). Higher P input with leaf litter and faster transportation into the ground was observed when beech was less abundant. Generally, there were low P concentrations in soil and leaf litter (Talkner et al. 2009). Tree species had strong influence on leaf litter decomposition, nutrient release (Jacob 2010) and small-scale differences of soil properties (Langenbruch 2012). In these previous studies, species effects were dominant in affecting nutrient cycling at Hainich forest. 
Part B - Recent research and hypotheses

There is no general answer to the question of whether species richness increases forest productivity. Globally, a high species number on a small scale produced large biomass, but this did not prove to be the case on a larger scale due to a strong influence of environmental gradients (Chisholm et al. 2013). A modeling study suggests that complementarity has a strong influence on temperate forest productivity (Morin et al. 2011). For managed temperate forest, the difference between complementary and similar functional traits can increase or decrease productivity by up to $30 \%$ (Pretzsch 2003) but such effects could not be shown for complementary canopy fillings at Hainich (Seidel et al. 2013). In Chapter 1 of this work, we hypothesized that:

(Hypothesis 1.1) mix-species stands are more productive than mono-species stands.

Nitrogen limits the productivity of unpolluted temperate and boreal forests (Vitousek 1982, Hedin et al. 1995). But high N deposition in Germany (Builtjes et al. 2011) may alleviates this limitation (e.g., Corre et al. 2003, 2007) and beech stands in Germany were shown to be partly P deficient (Ilg et al. 2009). Some deciduous tree species have also been shown to respond to K fertilization (Tripler et al. 2006). In Chapter 1, we also hypothesized that:

(Hypothesis 1.2) nutrient limitation is species-dependent.

Nutrient response efficiency curves (biomass production divided by soil nutrient availability, Bridgham et al. 1995) allows conclusions on whether a nutrient is limiting; or is used at optimum efficiency; or is saturated (Pastro and Bridgham 1999). Combined with a neighborhood approach, i.e., looking at a species' performance within different species compositions (Rothe and Binkley 2001), we can look behind the mechanisms of productivity and nutrient availability for each species. We hypothesized in Chapter 1 that:

(Hypothesis 1.3) mix-species stands use soil nutrient elements more efficiently than mono-species stands. 
As will be shown in Chapter 1, we found $\mathrm{P}$ and $\mathrm{K}$ limiting for mono-species stands of beech, but not in mixed-species stands, where higher productivity related to higher availability of $\mathrm{P}$ and $\mathrm{K}$. Based on these findings, four our second chapter, we hypothesized that:

(Hypothesis 2.1) tree species diversity enhances nutrient turnover in the litter layer, which will result in larger nutrient availability in the soil and correspondingly in foliar nutrient levels.

During leaf litter decomposition, a key role of nutrient and energy transfer is played by the microbial biomass (Singh and Gupta 1977). They absorb (immobilize) nutrients when the decomposing litter does not provide a sufficient amount, which is common for $\mathrm{N}$ and has also been reported for $\mathrm{P}$ (Prescott 2005). Competition for nutrients between microbial biomass and trees can be expected when they limit the growth of both. Such competitions has been shown for barley, grasslands and beech trees (for N, Inselsbacher et al. 2010; Bardgett et al. 2003; Dannemann et al. 2009) as well as for tropical peatlands (for P, Sjögertsen et al. 2011). Therefore, we hypothesized in Chapter 2 that:

(Hypothesis 2.2) as opposed to the mixed-species stands, the mono-species beech stands will have a strong competition between trees and microbial biomass for $P$ and $K$.

Chapter 3 leaves the research area of nutrient cycling but sticks with competitive effects - more specifically those between tree species in our research area. Beech, Central Europe's most successful plant species (Leuschner et al. 2006) potentially forms large areas of beech forests and mixed beech forests (Bohn et al. 2000). Oak can, however, be dominant over beech where it is too dry, as in the eastern part of the Hainich forest (Ellenberg and Leuschner 2010). A decline of oak is happening in Europe (Oszaka 1997) and may be associated with draught stress and high nitrogen deposition (Thomas et al. 2002). Based on this, we hyposesized that

(Hypothesis 3.1) in recent decades the relative competitiveness of oak has declined due to increased $N$ deposition.

Competitive interactions in mixed forests may be characterized by the presence of higher interspecific competition (Crawley 1997), intraspecific competition (Röhrig et al. 2006; Begon et al. 2006) or a shifting from one to the other (Getzin et al. 2006). In Chapter 3, we tested the hypothesis that: 
(Hypothesis 3.2) intraspecific competition is greater than interspecific competition.

Temperate forests are heterogeneous in space and time (Closset-Kopp et al. 2006), establishment and abundance of species depending on many factors such as, e.g., disturbance, soilnutrient heterogeneity, competition or herbivory (Nakashizuka 2001; Burrascano et al. 2008, Crawley 1997). Mature temperate deciduous forests show a 'shifting mosaic steady state' of different tree ages and compositions with greater dbh and height in later stages (Emborg et al. 2000). For our forest which has been defined as 'very close to the natural vegetation' (Nationalparkverwaltung Hainich 2008), we finally hypothesized that

(Hypothesis 3.3) stands of different compositions represent stages in stand development.

In the following Chapters 1 to 3, these hypotheses will be tested, followed by a synthesis, in which our key findings will be presented.

\section{References}

Bardgett, R.D., Streeter, T.C., Bol, R., 2003. Soil microbes compete effectively with plants for organic-nitrogen inputs to temperate grasslands. Ecology 84, 1277-1287. doi:10.1890/00129658(2003)084[1277:SMCEWP]2.0.CO;2

Begon, M., Townsend, C.R., Harper, J.L., 2006 Ecology: From Individuals to Ecosystems, 4th Edition. ed. Blackwell Publishing.

Bohn, U.; Gollub, G. \& Hettwer, C., 2000. Map of the Natural Vegetation of Europe. Scale 1:2.500.000. Part 2: Legend and Part 3: Maps. Münster, Germany.

Bridgham, S. D., Pastor, J., McClaugherty, C. A., Richardson, C. J., 1995. Nutrient-use efficiency: a litterfall index, a model, and a test along a nutrient-availability gradient in North Carolina peatlands. American Naturalist 145, 1-21.

Builtjes, P., Hendriks, E., Koenen, M., Schaap, M., Banzhaf, S., Kerschbaumer, A. Gauger, T., Nagel, H.D. Scheuschner, T., Schlutow, A., 2011. Erfassung, Prognose und Bewertung von Stoffeinträgen und ihren Wirkungen in Deutschland-Zusammenfassender Abschlussbericht. Umweltbundesamt. Dessau-Rosslau, Germany. Appendix 11.

Burrascano, S., Lombardi, F., Marchetti, M., 2008. Old-growth forest structure and deadwood: Are they indicators of plant species composition? A case study from central Italy. Plant Biosystems 142, 313-323. doi:10.1080/11263500802150613

Chen, J., Saunders, S.C., Crow, T.R., Naiman, R.J., Brosofske, K.D., Mroz, G.D., Brookshire, B.L., Franklin, J.F., 1999. Microclimate in Forest Ecosystem and Landscape Ecology Variations in local climate can be used to monitor and compare the effects of different management regimes. BioScience 49, 288-297.

doi:10.2307/1313612 
Chisholm, R.A., Muller-Landau, H.C., Abdul Rahman, K., Bebber, D.P., Bin, Y., Bohlman, S.A., Bourg, N.A., Brinks, J., Bunyavejchewin, S., Butt, N., Cao, H.L., Cao, M., Cardenas, D., Chang, L.W., Chiang, J.M., Chuyong, G., Condit, R., Dattaraja, H.S., Davies, S., Duque, A., Fletcher, C., Gunatilleke, N., Gunatilleke, S., Hao, Z.Q., Harrison, R.D., Howe, R., Hsieh, C.F., Hubbell, S.P., Itoh, A., Kenfack, D., Kiratiprayoon, S., Larson, A.J., Lian, J.Y., Lin, D.M., Liu, H.F., Lutz, J.A., Ma, K.P., Malhi, Y., McMahon, S., McShea, W., Meegaskumbura, M., Razman, S.M., Morecroft, M.D., Nytch, C.J., Oliveira, A., Parker, G.G., Pulla, S., Punchi-Manage, R., Romero-Saltos, H., Sang, W.G., Schurman, J., Su, S.H., Sukumar, R., Sun, I.F., Suresh, H.S., Tan, S., Thomas, D., Thomas, S., Thompson, J., Valencia, R., Wolf, A., Yap, S., Ye, W.H., Yuan, Z.Q., Zimmerman, J.K., 2013. Scale-dependent relationships between tree species richness and ecosystem function in forests. Journal of Ecology 101, 1214-1224.

Closset-Kopp, D., Schnitzler, A., \& Aran, D. (2006). Dynamics in natural mixed-beech forest of the Upper Vosges, in: Hawksworth, David L., Bull, Alan T. (Eds.), Forest Diversity and Management. Springer Netherlands, pp. 3-33.

Corre, M. D., Beese, F. O., Brumme, R., 2003. Soil nitrogen cycle in high nitrogen deposition forest: changes under nitrogen saturation and liming. Ecological Applications 13, 287-298.

Corre, M. D., Brumme, R., Veldkamp, E., Beese, F. O., 2007. Changes in nitrogen cycling and retention processes in soils under spruce forests along a nitrogen enrichment gradient in Germany. Global Change Biology 13, 1509-1527.

Crawley, M.J., 1990. The population dynamics of plants. Philosophical Transactions of the Royal Society B: Biological Sciences 330.1257, 125-140.

Crawley, M.J., 1997. Life History and Environment, in: Crawley, M.J. (Ed.), Plant Ecology. Blackwell Publishing Ltd., pp. 73-131.

Dannenmann, M., Simon, J., Gasche, R., Holst, J., Naumann, P.S., Kögel-Knabner, I., Knicker, H., Mayer, H., Schloter, M., Pena, R., Polle, A., Rennenberg, H., Papen, H., 2009. Tree girdling provides insight on the role of labile carbon in nitrogen partitioning between soil microorganisms and adult European beech. Soil Biology and Biochemistry 41, 1622-1631. doi:10.1016/j.soilbio.2009.04.024

Ducousso, A., Bordacs, S., 2004. EUFORGEN Technical Guidelines for genetic conservation and use for pedunculated and sessile oaks (Quercus robur and Q. petraea). International Plant Genetic Resources Institute, Rome, Italy. 6 pages.

EEA, 2008. European forests - ecosystem conditions and sustainable use. European Environmental Agency, Copenhagen, Denmark.

Ellenberg, H., Leuschner, C., 2010. Vegetation Mitteleuropas mit den Alpen: In ökologischer, dynamischer und historischer Sicht, UTB, Stuttgart.

Emborg, J., Christensen, M., Heilmann-Clausen, J., 2000. The structural dynamics of Suserup Skov, a near-natural temperate deciduous forest in Denmark. Forest Ecology and Management 126, 173-189. doi:10.1016/S0378-1127(99)00094-8

Finck, A. 1969. Pflanzenernährung in Stichworten. Hirt, Kiel.

Getzin, S., Dean, C., He, F., A. Trofymow, J., Wiegand, K., Wiegand, T., 2006. Spatial patterns and competition of tree species in a Douglas-fir chronosequence on Vancouver Island. Ecography 29, 671-682. doi:10.1111/j.2006.0906-7590.04675.x

GRK 1086. The Role of Biodiversity for Biogeochemical Cycles and Biotic Interactions in Temperate Deciduous Forests https://www.uni-goettingen.de/en/project/82905.html

Guckland, A. 2009. Nutrient stocks, acidity, processes of N transformation and net uptake of methane in soils of a temperate deciduous forest with different abundance of beech (Fagus sylvatica L.). PhD thesis. GeorgAugust-University of Goettingen.

Hedin, L. O., Armesto, J. J., Johnson, A. H., 1995. Patterns of nutrient loss from unpolluted, old-growth temperate forests: evaluation of biogeochemical theory. Ecology 76, 493-509. 
Ilg, K., Wellbrock, N., Lux, W., 2009. Phosphorus supply and cycling at long-term forest monitoring sites in Germany. European Journal of Forest Research 128, 483-492.

Inselsbacher, E., Hinko-Najera Umana, N., Stange, F.C., Gorfer, M., Schüller, E., Ripka, K., Zechmeister-Boltenstern, S., Hood-Novotny, R., Strauss, J., Wanek, W., 2010. Short-term competition between crop plants and soil microbes for inorganic $\mathrm{N}$ fertilizer. Soil Biology and Biochemistry 42, 360-372. doi:10.1016/j.soilbio.2009.11.019

Jacob, M. 2010. Productivity and nutrient relations of trees in deciduous forests differing in tree species diversity. Biodiversity and Ecology Series B 5, 1-39.

Köhl, M., San-Miguel-Ayanz, J., 2002. Pan-European Quantitative Indicators for Sustainable Forest Management, in: State of Europe's Forests 2011. Status \& Trends in Sustainable Forest Management in Europe. FOREST EUROPE, UNECE, FAO, pp. 15-141.

Langenbruch, C. 2012. Effects of nutrient cycling through litter of different broadleaved deciduous tree species on soil biochemical properties and the dynamics of carbon and nitrogen in soil. PhD thesis. Georg-AugustUniversity of Goettingen.

Larcher, W., 2003. Physiological plant ecology: ecophysiology and stress physiology of functional groups. Springer, Berlin, Heidelberg, New York.

Leuschner, C., Meier, I. C., Hertel, D., 2006. On the niche breadth of Fagus sylvatica: soil nutrient status in 50 Central European beech stands on a broad range of bedrock types. Annals of Forest Science 63, 355-368.

Mölder, A., Bernhard-Römermann, M., Schmidt, W., 2006. Forest ecosystem research in Hainich National Park (Thuringia): first results on flora and vegetation in stands with contrasting tree species diversity, Waldökologie online 3, 83-99.

Morin, X., Fahse, L., Scherer-Lorenzen, M., Bugmann, H., 2011. Tree species richness promotes productivity in temperate forests through strong complementarity between species. Ecology Letters 14, 1211-1219.

Nakashizuka, T., 2001. Species coexistence in temperate, mixed deciduous forests. Trends in Ecology \& Evolution 16, 205-210. doi:10.1016/S0169-5347(01)02117-6

Nationalparkverwaltung Hainich, 2008. Wälder im Nationalpark Hainich. Ergebnisse der 1. Stichprobeninventur 1999-2001., Erforschen Band 1. Bad Langensalza, Germany.

Oszako, T., 1997. Oak decline in European forests. First EUFORGEN Meeting on Social Broadleaves 145-151.

Pastor, J., Bridgham, S. D., 1999. Nutrient efficiency along nutrient availability gradients. Oecologia 118, 50-58.

Prescott, C.E., 2005. Do rates of litter decomposition tell us anything we really need to know? Forest Ecology and Management 220, 66-74. doi:10.1016/j.foreco.2005.08.005

Pretzsch, H., 2003. Diversität und Produktivität von Wäldern. Allgemeine Forst-und Jagdzeitung 174, 88-98.

Reich, P.B., Frelich, L. (2002): Temperate Deciduous Forests, in: Munn, T. (Ed.). Encyclopedia of Global Environmental Change, Volume 2: Mooney, H.A., Canadell, J.G. (Eds.). The Earth System: biological and ecological dimensions of global environment. John Wiley \& Sons, Ltd, Chichester

Röhrig, E., Bartsch, N., Lüpke, B. von, Dengler, A., 2006. Waldbau auf ökologischer Grundlage. Ulmer.

Rothe, A., Binkley, D., 2001. Nutritional interactions in mixed species forests: a synthesis. Canadian Journal of Forest Research 31, 1855-1870.

Seidel, D., Leuschner, C., Scherber, C., Beyer, F., Wommelsdorf, T., Cashman, M. J., Fehrmann, L., 2013. The relationship between tree species richness, canopy space exploration and productivity in a temperate broad-leaf mixed forest. Forest Ecology and Management 310, 366-374.

Singh, J., Gupta, S., 1977. Plant Decomposition and Soil Respiration in Terrestrial Ecosystems. Botanical Review 43, 499-528.

Sjögersten, S., Cheesman, A.W., Lopez, O., Turner, B.L., 2011. Biogeochemical processes along a nutrient gradient 
in a tropical ombrotrophic peatland. Biogeochemistry 104, 147-163. doi:10.1007/s10533-010-9493-7

Talkner, U., Jansen, M., Beese, F.O., 2009. Soil phosphorus status and turnover in central-European beech forest ecosystems with differing tree species diversity. European Journal of Soil Science 60, 338-346. doi:10.1111/j.1365-2389.2008.01117.x

Thomas, F.M., Blank, R., Hartmann, G., 2002. Abiotic and biotic factors and their interactions as causes of oak decline in Central Europe. Forest Pathology 32, 277-307. doi:10.1046/j.1439-0329.2002.00291.x

Trapp, E., 1938. Untersuchungen über die Verteilung der Helligkeit in einem Buchenbestand. Bioklimat. Beibl. Meteor. Z. 5, 153-158.

Tripler, C. E., Kaushal, S. S., Likens, G. E., Todd Walter, M., 2006. Patterns in potassium dynamics in forest ecosystems. Ecology Letters 9, 451-466.

Kozlowski, T.T., Kramer, P.J., Pallardy, S.G., 1991. The Physiological Ecology of Woody Plants. Academic Press, San Diego, London.

Svejgaard Jensen, J., 2003. EUFORGEN Technical Guidelines for genetic conservation and use for lime (Tilia spp.). International Plant Genetic Resources Institute, Rome, Italy. 6 pages.

Vitousek, P., 1982. Nutrient cycling and nutrient use efficiency. American Naturalist 119, 553-572.

von Wuehlisch G., 2008. EUFORGEN Technical Guidelines for genetic conservation and use for European beech (Fagus sylvatica). Bioversity International, Rome, Italy. 6 pages. 
Chapter 1 


\title{
1. Tree species diversity effects on productivity, soil nutrient availability and nutrient response efficiency in a temperate deciduous forest
}

\author{
Marcus Schmidt, Edzo Veldkamp, Marife D. Corre \\ Published in Forest Ecology and Management, Volume 338, 15 February 2015
}

\begin{abstract}
There are contrasting reports whether and how tree diversity influences stand productivity in temperate deciduous forests. Tree species diversity may increase stand productivity in temperate forests through complementary resource use and/or facilitation if the resource considered limits productivity. In unpolluted temperate forests, net primary production is typically limited by nitrogen (N). However, in many parts of Europe high $\mathrm{N}$ deposition has alleviated $\mathrm{N}$ limitation and there is some evidence that phosphorus ( $\mathrm{P}$ ) and/or potassium ( $\mathrm{K}$ ) limitation has become more widespread. Here, we report on a study where we investigated whether complementarity and/or facilitation increase productivity in a typical German deciduous forest with tree species of beech (Fagus sylvatica), oak (Quercus petraea and Quercus robur), hornbeam (Carpinus betulus) and lime (Tilia cordata and Tilia platyphyllus). We measured biomass production and availability of soil N, P, K, calcium ( $\mathrm{Ca}$ ) and magnesium (Mg) in stands of single species (mono-species stands) and in stands with different combinations of three of the tree species above (mix-species stands). We used nutrient response efficiency (NRE) to evaluate whether a specific nutrient limits tree growth. At a stand level, above-ground net primary productivity did not differ between mono- and mix-species stands. At a tree level, using a neighborhood approach, relative growth rates of beech trees in mono-species stands were smaller than when they were in mix with lime and hornbeam whereas growth of lime trees in mono-species stands was larger than in mix with beech and oak. The NRE curve for beech showed that beech trees in mix-species stands had optimal P and $\mathrm{K}$ response efficiencies whereas beech trees in mono-species stands showed $\mathrm{P}$ and $\mathrm{K}$ limitations. The NRE curve for oak with exchangeable soil $\mathrm{K}$ showed that $\mathrm{K}$ levels were beyond the optimum NRE and thus $\mathrm{K}$ was not limiting oak growth. NRE curves for hornbeam and lime showed no significant relationships with any of the soil nutrients. Hence, nutrient limitation was species-dependent. Our results showed that using both NRE and a neighborhood approach are useful tools in quantifying the effects of individual tree
\end{abstract}


species on a species' productivity between mono- and mix-species stands. Such tools provide important basis for improving management of typical mix-species, temperate forests.

\subsection{Introduction}

Species composition can alter ecosystem properties through functional traits and interactions (Hooper et al. 2005). In many experiments in grasslands where species composition was manipulated, it has been shown that biodiversity increases productivity (Loreau et al. 2001) and it was recently suggested that biodiversity in such ecosystems may be as important for productivity as the availability of growth-limiting nutrients (Tilman et al. 2012). In forest ecosystems there are, however, conflicting reports on the effects of species richness on productivity. While a positive influence has been reported in tree plantations (Piotto 2008) as well as in boreal (Paquette and Messier 2011) and early-successional Mediterranean (Vilà et al. 2005 and Vilà et al. 2007) forests, it has been suggested that biodiversity is less important in temperate forests growing in a stable, productive environment (Paquette and Messier 2011). In an unmanaged temperate forest in central Germany, plots with $40 \%$ beech and the rest accounted for by ash, lime, hornbeam and maple had lower above-ground net primary production than plots with $89 \%$ beech (Jacob et al. 2010). Since beech was, however, the dominant species, such effect may not be due to the number of tree species but to beech abundance. Indeed, in the same study area, no relationship was found between tree species richness and above-ground net primary production (Seidel et al. 2013). This result is in contrast with a modeling study showing that species richness increases productivity in temperate deciduous forests (Morin et al. 2011). In summary, there are contrasting reports whether and how tree species diversity influences stand productivity in temperate deciduous forests.

There are three mechanisms through which tree species diversity can increase forest productivity: facilitation, complementary resource use and the sampling effect (Fridley 2001). Facilitation occurs when one species positively alters the environment in favor of another (Vandermeer 1989). A Californian oak species (Quercus douglasii) was able to facilitate growth of the herbal layer by providing additional nutrients, although the effect was often overlain by root interference (Callaway et al. 1991). Also, in successional post-glaciation sites in Glacier Bay, Alaska, communities of Sitka alder (Alnus sinuata) facilitated growth of late-succession Sitka spruce (Picea sitchensis) (Chapin et al. 1994). Complementarity reduces competition between species by resource partitioning (Fridley 2001 and Hooper et al. 2005). Evaluation of available data from economically-relevant temperate and boreal tree species showed that complementary functional traits, such as high and low tolerance of shade, can increase productivity by up to $30 \%$ whereas similar functional traits and ecological amplitudes 
increase competition and can decline stand productivity by up to $30 \%$ (Pretzsch 2003). However, in central Germany, complementary canopy filling of stands with multiple species did not affect productivity (Seidel et al. 2013). A sampling effect addresses the greater chance of choosing highlyproductive or better-adapted species or of encountering complementarity or facilitation in high versus low species-diversity communities (Fridley 2001). Facilitation, complementary resource use as well as the sampling effect is sensitive to environmental conditions, scale of observation and human impact (Fridley 2001). For example, in a global study, at small-scale plots high tree species number produced large biomass whereas this relationship did not hold for larger plots where environmental gradients were proposed to be more important drivers of productivity than was tree species richness (Chisholm et al. 2013).

Tree species diversity has the potential to increase productivity in a temperate forest through facilitation and/or complementary resource use if the resource considered limits productivity. In unpolluted temperate and boreal forests, net primary production is limited by nitrogen (N) (Vitousek 1982 and Hedin et al. 1995). In many parts of Germany, however, high N deposition has alleviated N limitation (e.g., Corre et al. 2003 and Corre et al. 2007), which may have resulted in nutrient limitations other than $\mathrm{N}$. Furthermore, $\mathrm{N}$ deposition has the potential to reduce phosphorus $(\mathrm{P})$ uptake by trees through inhibiting plant-mycorrhizal association (Braun et al. 2010). This was for example reflected in German beech stands of which $23 \%$ showed P deficiency in at least one year (Ilg et al. 2009). In a review of studies examining growth of deciduous tree species with potassium (K) fertilization, 7 out of 9 studies showed positive response to increased $\mathrm{K}$ availability in forest soils (Tripler et al. 2006).

The efficiency with which trees convert nutrients into biomass is an important measure that determines whether or not tree species diversity can increase productivity in temperate forests. The first study that evaluated nutrient use efficiency of forests uses an index of litterfall, organic matter increment and root turnover divided by litterfall nutrient concentration (Vitousek 1982). Later, nutrient response efficiency (biomass production divided by soil nutrient availability, Bridgham et al. 1995) was successfully tested in various ecosystems and at different scales. NRE is a suitable index to evaluate biodiversity effects on productivity since it determines, together with soil nutrient availability, whether complementary nutrient use and/or facilitation of trees affect productivity. Hence, these mechanisms will increase productivity only if differences in soil nutrient availability and nutrient response efficiencies of tree species are sufficiently large and competitive interactions are not dominant.

In the present study our objectives were to (1) determine whether tree species diversity affected productivity both at stand and tree levels, (2) assess whether tree species affected plant-available N, P, calcium (Ca), $\mathrm{K}$ and magnesium (Mg) in the soil, and (3) evaluate which soil nutrient elements limit 
productivity based on NRE curves. We hypothesized that in our study area, a deciduous forest in central Germany dominated by four species, (1) mix-species stands are more productive than mono-species stands, (2) nutrient limitation is species-dependent, and (3) mix-species stands use soil nutrient elements more efficiently than mono-species stands. We discuss the practical implications of our findings for forest management.

\subsection{Methods}

\subsubsection{Site description}

Our study was conducted in the Hainich national park, which represents the largest unmanaged deciduous forest ecosystem in central Germany. It contains tree communities typical for Central Europe (Mölder et al. 2006). Our research site was an area of about 25 ha, defined as 'very close to the natural vegetation' (Nationalparkverwaltung Hainich 2008), has an average slope of $4^{\circ}$, and is located near the town of Weberstedt, Thuringia, Germany $\left(51^{\circ} 6^{\prime} \mathrm{N}, 10^{\circ} 30^{\prime} \mathrm{E}\right)$. The soil's parent material is a Triassic limestone, covered by up to $50 \mathrm{~cm}$ of loess. The soil is a Cambisol with texture between silt loam and silty clay loam (Appendix 1.I).

\subsubsection{Stand selection}

The four most common trees species in the study site were beech (Fagus sy/vatica), oak (Quercus petraea and Quercus robur), hornbeam (Carpinus betulus) and lime (Tilia cordata and Tilia platyphyllus). Oak was mainly Q.petraea with only a few trees of Q.robur. Lime could not be differentiated in the field: $87 \%$ of lime trees at the site were found to be T.cordata, $4 \%$ T.platyphyllus and $9 \%$ hybrids (Rajendra 2009). We selected stands for each of the four tree species, which we call 'mono-species stands' hereafter, and stands consisting of three out of these four species, which we call 'mix-species stands' hereafter. Each stand had between 4 and 8 trees and was replicated 6 times (4 mono- and 4 mix-species stands $\times 6$ plots $=48$ stands). The area of each stand was determined by creating Voronoi-polygons (Mead 1966) around each tree composing a stand and calculating the total stand area using Quantum GIS (QGIS Development Team 2012). The stand area ranged from 68 to $313 \mathrm{~m}^{2}$. Our stand selection criteria were: (a) each stand should have similar tree species composition surrounding it, (b) all trees in a stand should have a diameter at breast height ( $\mathrm{dbh}$ ) larger than $10 \mathrm{~cm}$ and a well-developed crown as an indicator that they actively grew, and (c) initial field survey must show similar soil characteristics (e.g., color, field test for soil texture, slope, drainage, among others). Following stand selection, a detailed soil chemical analysis was conducted (see Section 1.2.4 below). 


\subsubsection{Biomass production}

Stem diameter increment was measured using dendrometer bands (D1, UMS GmbH, München), which were permanently installed two months prior to the first measurement and were measured three times from July 2012 to July 2013. We expressed stem diameter growth as relative growth rate, i.e., stem diameter increment per diameter at breast height $(\mathrm{dbh})$. Analysis of relative growth rates were conducted both at a stand level (averaging the 4-8 trees that comprised one replicate stand) and at a tree level (considering individual trees). For the latter, we checked whether relative growth rates of individual trees were dependent on $\mathrm{dbh}$, which was the case for beech, oak and hornbeam. These three species were divided into two dbh size classes (i.e., small with $0.1-0.4 \mathrm{~m}$ dbh, and large with $>0.4 \mathrm{~m}$ $\mathrm{dbh}$ ), resulting in $\mathrm{dbh}$-independent relative growth rates within each class, for which tree-level comparisons were done separately. Since oak trees in small dbh class and hornbeam trees in large dbh class were only very few, the statistical comparisons for oak in the small dbh class and hornbeam in the large dbh class were not conducted. For both stand and tree-level comparisons, differences were assessed (a) among mono-species stands and (b) between each mono-species stand with its corresponding mix-species stands. Furthermore, above-ground woody biomass production (AWBP) in each stand was calculated using allometric equations for each species (for beech and hornbeam, Wirth et al. 2004; for oak, Cienciala et al. 2008; for lime, Bunce 1968) and expressed as the sum of AWBP of the trees composing a stand divided by the stand area (see Section 1.2.2 above). We collected fine litterfall, i.e., leaves and reproductive parts, in each stand with one litter trap of $0.5 \mathrm{~m}^{2}$ area, placed in the middle of each stand at $1 \mathrm{~m}$ above the ground to exclude herbs and shrubs on the forest floor. Litter was collected biweekly in the fall of 2011 and 2012 and averaged over both years. Above-ground net primary production (ANPP) in each stand was calculated as the sum of AWBP and fine litterfall. Comparisons among mono- and mix-species stands for AWBP, fine litterfall and ANPP were conducted at the stand level.

Since allometric equations are approximations and in our case some trees laid outside the given range of a specific equation, we used relative growth rates and not AWBP for the calculation of NRE and in analyzing relationships between tree growth or productivity and soil nutrient availability (see Section 1.2 .5 below).

\subsubsection{Soil nutrient availability and biochemical characteristics}

Plant-available $\mathrm{N}$ was calculated as the sum of annual net $\mathrm{N}$ mineralization in the soil and atmospheric $\mathrm{N}$ deposition. For net $\mathrm{N}$ mineralization, the in-situ buried bag method (Page et al. 1994) was 
used. At each stand, two intact soil cores were taken in the top 0.1-m depth. One core was extracted immediately in the field with $0.5 \mathrm{M} \mathrm{K}_{2} \mathrm{SO}_{4}$ solution $\left(T_{0}\right)$. The second core was placed in a plastic bag and inserted back into the soil to incubate in-situ for 10 days $\left(T_{1}\right)$ and then extracted in the manner as the $T_{0}$ cores. The in-situ buried bag method excludes $\mathrm{N}$ uptake by plants, and thus net $\mathrm{N}$ mineralization is used as an index of the mineral $\mathrm{N}$ internally produced in the soils that is available for plant uptake (Hart et al. 1994). Net $\mathrm{N}$ mineralization was calculated as the sum of nitrate $\left(\mathrm{NO}_{3}{ }^{-}\right)$and ammonium $\left(\mathrm{NH}_{4}{ }^{+}\right)$ at $T_{1}$ minus the sum of $\mathrm{NO}_{3}{ }^{-}$and $\mathrm{NH}_{4}{ }^{+}$at $T_{0}$. Concentrations of $\mathrm{NO}_{3}{ }^{-}$and $\mathrm{NH}_{4}{ }^{+}$were measured using continuous flow injection colorimetry (SEAL Analytical AA3, SEAL Analytical GmbH, Norderstedt, Germany). Net N mineralization was measured in March, May, July, September and November of 2012 and the cumulative net $\mathrm{N}$ mineralization in a year was calculated using the trapezoid rule between measured rates of net $\mathrm{N}$ mineralization rates and time intervals of measurements. Estimated total atmospheric $\mathrm{N}$ deposition in our study area was $25 \mathrm{~kg} \mathrm{~N} \mathrm{ha}^{-1}$ year $^{-1}$ (Builtjes et al. 2011).

Plant-available P was determined in March, July and November 2012 from soil samples taken in the top 0.1-m depth. We used the method of resin- and sodium bicarbonate-extractable $P\left(P_{\text {resin }}\right.$ and $\mathrm{P}_{\mathrm{NaHCO}}$ ). These two extractions are part of the widely-used Hedley fractionation (Tiessen and Moir 1993) and are assumed to represent the fraction of soil $\mathrm{P}$ that is available to plants (Cross and Schlesinger 1995). For $P_{\text {resin, }} 1 \mathrm{~g}$ of anion exchange resin (analytical grade, 20-50 mesh DOWEX ${ }^{\circledR}$ 1X8; SERVA Electrophoresis $\mathrm{GmbH}$, Heidelberg, Germany) was put in an unused empty tea bag. This resin bag was put in a mixture of $0.5 \mathrm{~g}$ of soil and $30 \mathrm{ml}$ of distilled water. After overnight shaking, the resin was cleaned from sticking soil particles, put in $20 \mathrm{ml}$ of $0.5 \mathrm{~mol} \mathrm{~L}^{-1} \mathrm{HCl}$ and shaken overnight. For $\mathrm{P}_{\mathrm{NaHCO}}$, the soil from which $\mathrm{P}_{\text {resin }}$ had been previously extracted was filled with $30 \mathrm{ml}$ of $0.5 \mathrm{~mol} \mathrm{~L}^{-1} \mathrm{NaHCO}_{3}$, shaken overnight and the extracts were filtered. Both $P_{\text {resin }}$ and $P_{\text {NaHCO3 }}$ extracts were determined for $P$ concentrations using an inductively coupled plasma-atomic emission spectrometer (ICP-AES, iCAP 6300 Duo VIEW ICP Spectrometer; Thermo Fischer Scientific GmbH, Dreieich, Germany).

Bulk density was measured using the core method (Blake and Hartge 1986), i.e., collecting intact soil cores of known volume and determining the dry soil mass after drying for one day at $105^{\circ} \mathrm{C}$. Effective cation exchange capacity (ECEC) of the soils, including exchangeable $\mathrm{Ca}, \mathrm{K}$ and $\mathrm{Mg}$ which are normally used as indices of macronutrients in the soil available for plant uptake, was determined from soil samples taken in the top 0.1-m depth in 2012. The soils were air-dried, sieved through a 2-mm sieve and percolated with unbuffered $1 \mathrm{~mol} \mathrm{~L}^{-1} \mathrm{NH}_{4} \mathrm{Cl}$. Concentrations of cations in the percolates were determined using the ICP-AES. Base saturation is calculated as the percentage base cations ( $\mathrm{Ca}, \mathrm{K}, \mathrm{Mg}$ and $\mathrm{Na}$ ) of the ECEC. Soil pH in the top 0.1-m depth was measured from the sieved samples with a soil to distilled water ratio of 1:4. Total soil organic $C$ and $N$ in the top 0.1-m depth were determined from 
sieved, ground samples and analyzed using a CN analyzer (Elementar Vario EL; Elementar Analysis Systems $\mathrm{GmbH}$, Hanau, Germany). Total soil P in the top 0.1-m depth was analyzed from the sieved, ground samples by pressure digestion in concentrated $\mathrm{HNO}_{3}$ followed by analysis of the digests using the ICP-AES. Comparisons among mono- and mix-species stands for these soil parameters were done at a stand level.

\subsubsection{Growth curves and nutrient response efficiency curves}

To describe biomass production as a function of soil nutrient availability, a Michaelis-Menten equation was used (Bridgham et al. 1995, based on Monod 1942):

Production $=\frac{\left(\text { Nutrient }_{\mathrm{av}}-\text { Nutrient }_{\min }\right) \text { Production }(\mathrm{P})_{\max }}{\left(\text { Nutrient }_{\mathrm{av}}-\text { Nutrient }_{\min }\right)+\text { Nutrient }_{\text {at } 0.5 \mathrm{P}_{\max }}}$

Production thus depends on the (a) availability of an essential soil nutrient (Nutrient $\mathrm{av}_{\mathrm{av}}$ ), (b) soil nutrient level at zero plant biomass production (Nutrient ${ }_{\min }$ ), (c) maximum biomass production (Production max $_{\text {) }}$ with this soil nutrient, and (d) plant requirement of this soil nutrient to reach half of its maximum production (Nutrient $t_{\text {at } 0.5 \text { Pmax }}$ ) (Monod 1942 and Bridgham et al. 1995).

Since NRE is biomass production divided by soil nutrient availability, it follows that (Bridgham et al. 1995):

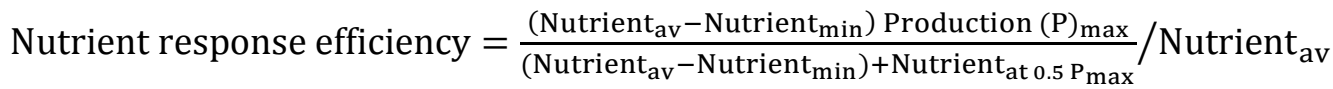

NRE is a unimodal curve with maximum efficiency occurring at medium nutrient levels (Fig. 1.1; Pastor and Bridgham 1999). This curve is based on the assumptions that at minimum availability of an essential nutrient plant biomass production is zero, that with increasing soil nutrient availability plant productivity increases, and that beyond a certain level of soil nutrient availability such soil nutrient stops being the limiting factor and plant productivity does not increase further with increase in that soil nutrient availability (Pastor and Bridgham 1999). Moreover, if production and nutrient availability are not related, the relation between the amount of soil nutrient ( $x$ axis) and plant biomass production ( $y$ axis) is a straight horizontal line, which is also called a non-relationship between soil nutrient availability and plant biomass production (Pastor and Bridgham 1999). In case of a non-relationship, NRE can be expressed as (Pastor and Bridgham 1999):

Nutrient response efficiency $=$ Constant production $/$ Nutrient $_{\mathrm{av}}$ 


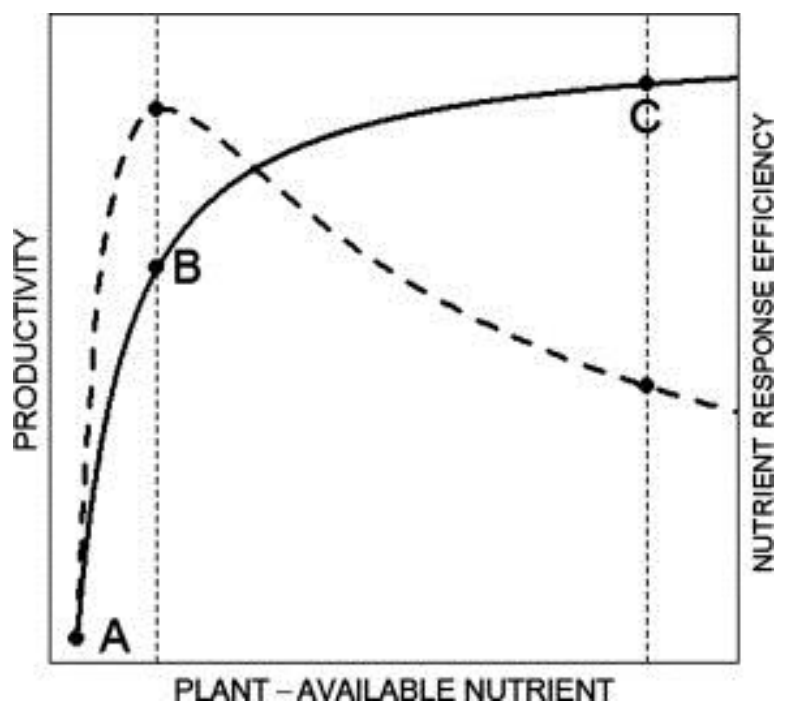

Fig. 1.1

Growth curve (solid line) and nutrient response efficiency (NRE) curve (dashed line) in the case of ideal dependency of productivity on a plant-available nutrient in the soil. (A) Zero productivity at minimum soil nutrient level; (B) productivity at optimum NRE; (C) maximum productivity at nutrient saturation (adapted from Pastor and Bridgham (1999)).

Mathematically, this results in decreasing NRE with increasing soil nutrient availability - or a monotonic increase in NRE as soil nutrient availability declines (Pastor and Bridgham 1999). A nonrelationship can occur either in a very infertile soil where plants can hardly respond to nutrient enhancement (Chapin et al. 1986) or in nutrient-saturated soils (Pastor and Bridgham 1999).

For plant biomass production and NRE, we used the relative growth rates at tree level (see Section 1.2.3 above) because different tree species (e.g., in a mix-species stand) may respond differently to different levels of soil nutrient availability. This method is termed as 'neighborhood approach' (i.e., looking at the performance of individual trees within a stand), which has been recommended when investigating relationships between soil nutrient availability and tree growth (Rothe and Binkley 2001). NRE of each tree species composing a stand was calculated as relative growth rates $\left(\mathrm{cm} \mathrm{cm}^{-1} \mathrm{dbh}\right)$ of the trees species per unit of soil nutrient level (i.e., plant-available $\mathrm{N}$ and $\mathrm{P}$, and exchangeable $\mathrm{K}, \mathrm{Ca}$ and $\mathrm{Mg}$ ) in a stand.

Growth (Eq. (1.1)) and NRE (Eq. (1.2)) curves were modeled using the nonlinear least square method. These curves were fitted to tree species that showed significant differences in relative growth rates, soil nutrient availability and/or NRE. Curve-fitting was done using R version 3.0.1 (R Development Core Team 2013). When the curve fits did not converge to the measured data, we tested whether a nonrelationship equation (Eq. (1.3)) resulted in a better fit. To evaluate the goodness of fit, we used the 
Pearson correlation test between fitted and observed values, because the use of regular $R^{2}$ was suggested to be inappropriate for nonlinear models (Spiess and Neumeyer 2010).

\subsubsection{Statistical analysis}

All data were tested for normality using the Shapiro-Wilk test and for equality of variances using Levene's test in ANOVA or a non-constant variance score test in ANCOVA (Fox and Weisberg 2011). We first tested the differences in soil texture among mono- and mix-species stands (Appendix 1), using oneway ANOVA with least significant difference test (for textural fraction that showed normal distribution and equal variances) or Kruskal-Wallis $\mathrm{H}$ test with multiple comparison extension (for textural fraction that showed non-normal distributions or unequal variances) (de Mendiburu 2014 and Giraudoux 2014). Even if we carefully selected all stands to have similar general soil and slope characteristics based from our initial field survey (see Section 1.2.2 above), silt and clay contents statistically differed among monospecies stands, although all replicate plots belong to the textural classes of silt loam and silty clay loam (Appendix 1.I). Such slight variations in silt and clay contents are however common in loess-covered soil landscapes. Hence, in the succeeding analyses for soil biochemical characteristics, stand characteristics, biomass production, relative growth rate, plant-available nutrients in the soil and NRE we used the clay content as a covariate and conducted analysis of covariance (ANCOVA) with Tukey HSD test to assess differences among mono- and mix-species stands (Hothorn et al. 2008). For any parameters that showed non-normal distribution or unequal variance, we used either log or square-root transformation. ANCOVA reduces the number of significant comparisons by accounting for the differences in clay contents, and thus emphasizing the influence of tree species compositions (e.g., Yamashita et al. 2008). Letters of significance therefore represent differences between adjusted means. For the parameter that was measured repeatedly over time (i.e., plant-available $\mathrm{P}$ in the soil), we used the linear mixed effects model (LME) followed by Tukey HSD test (Crawley 2002, Pinheiro et al. 2014 and Hothorn et al. 2008) with clay content as a covariate; in LME, tree species composition was considered as fixed effect and replicate stands and sampling time were included as random effects. Differences were considered statistically significant at $P \leqslant 0.05$ and, only for a few specified parameters, we also considered marginal significance at $P \leqslant 0.09$ because our experimental design encompassed the inherent spatial variability in our study area. Statistical analysis was conducted using R version 3.0.1 (R Development Core Team 2013). 


\subsection{Results}

\subsubsection{Soil characteristics and biomass production in mono-species stands}

Using statistical comparisons discounting the differences in clay contents (i.e., ANCOVA, see Section 1.2.6 above), soil biochemical characteristics in mono-species stands of beech and oak were comparable (Table 1.1). In general, lime stands displayed more favorable soil biochemical characteristics compared to beech, oak and hornbeam stands: lower C:N ratio and higher soil $\mathrm{pH}, \mathrm{ECEC}$ and base saturation (Table 1.1). Total soil $\mathrm{N}$ and $\mathrm{P}$ did not differ between these mono-species stands. Soil texture also differed between mono-species stands: soil in beech stands had higher silt and lower clay contents than the soil in hornbeam stands, and in the mid-range were soils in oak and lime stands (Appendix 1). Silt and clay contents did not differ between a mono-species stand and its corresponding mix-species stands. Although there were small differences in sand contents between a few mono- and mix-species stands, these were unimportant as sand contents ranged only from $1.1 \%$ to $1.9 \%$.

\section{Table 1.1}

Soil characteristics of mono-species stands in an unmanaged deciduous forest in central Germany, measured in the top 0.1-m depth in 2012.

\begin{tabular}{|c|c|c|c|c|c|c|c|}
\hline Composition & $\begin{array}{l}\text { Soil pH (1:4 } \\
\text { soil- } \mathrm{H}_{2} \mathrm{O} \text { ratio) }\end{array}$ & $\begin{array}{l}\text { Total } \\
\mathrm{C}^{\mathrm{a}}\left(\mathrm{Mg} \mathrm{C} \mathrm{ha}^{-1}\right)\end{array}$ & $\begin{array}{l}\text { Total } \mathrm{Na} \\
\left(\mathrm{Mg} \mathrm{N} \mathrm{ha-1}^{-1}\right)\end{array}$ & Soil C:N ratio & $\begin{array}{l}\text { Total } \\
\mathrm{P}^{\mathrm{a}}\left(\mathrm{Mg} \mathrm{P} \mathrm{ha}^{-1}\right)\end{array}$ & $\begin{array}{l}\text { Effective cation } \\
\text { exchange } \\
\text { capacity } \\
\left(\mathrm{mmol}_{\mathrm{c}} \mathrm{kg}^{-1}\right)\end{array}$ & $\begin{array}{l}\text { Base } \\
\text { saturation } \\
(\%)\end{array}$ \\
\hline Beech & $4.5(0.1) a b$ & $45.4(4.0) \mathrm{a}$ & $3.0(0.3) \mathrm{a}$ & $15.2(0.3) a b$ & $0.4(0.0) a$ & 104 (11) ab & 58 (9) ab \\
\hline Oak & $4.5(0.2) b$ & $42.7(4.4) a b$ & $2.7(0.3) a$ & $16.1(0.5) \mathrm{a}$ & $0.4(0.0) a$ & 106 (14) ab & $52(13) a b$ \\
\hline Hornbeam & $5.2(0.3) b$ & $64.0(14.0) a b$ & $4.5(0.8) a$ & $14.0(0.5) b c$ & $0.7(0.1) a$ & $229(66) b$ & $85(9) b$ \\
\hline Lime & $5.9(0.2) \mathrm{a}$ & $47.1(4.5) b$ & $3.8(0.3) \mathrm{a}$ & $12.4(0.3) \mathrm{c}$ & $0.6(0.1) a$ & 229 (34) a & 96 (3) a \\
\hline
\end{tabular}

Means (SE, $n=6$ replicate stands) in each column with different letter indicate significant differences among mono-species stands (ANCOVA with Tukey HSD test at $P \leqslant 0.05$ for all parameters except for base saturation of which $P=0.06$ ).

aFor total $\mathrm{C}, \mathrm{N}$ and $\mathrm{P}$, mass-based concentrations were expressed on area basis using the average soil bulk density of $1.21 \pm 0.02 \mathrm{~g} \mathrm{~cm}^{-3}$ measured in the top $0.1 \mathrm{~m}$.

Beech trees in mono-species stands were taller and larger in dbh than the other mono-species stands (Table 1.2). Also, mono-species stands of beech had a higher fine litterfall than oak and lime stands, of which the latter had the lowest fine litterfall (Table 1.2). Since 2011 was a mast year for beech, beech mono stands had twice the amount of fine litter fall in $2011\left(0.66 \mathrm{~kg} \mathrm{~m}^{-2}\right.$ year $\left.^{-1}\right)$ compared to 2012 $\left(0.33 \mathrm{~kg} \mathrm{~m}^{-2}\right.$ year $^{-1}$ ) due to high fruit production (58\% of fine litter fall in 2011 compared to 9\% in 2012). AWBP and ANPP did not differ between these mono-species stands. ANPP of mono-species stands 
ranged from $0.50 \mathrm{~kg} \mathrm{~m}^{-2}$ year $^{-1}$ to $1.23 \mathrm{~kg} \mathrm{~m}^{-2}$ year $^{-1}$ and had a mean of 0.79 ( $\left.\pm 0.05 \mathrm{SE}\right) \mathrm{kg} \mathrm{m}^{-2}$ year $^{-1}$ with resembling proportions of fine litterfall and AWBP (Table 1.2).

Table 1.2

Stand characteristics and biomass production of mono-species stands in an unmanaged deciduous forest in central Germany.

\begin{tabular}{llllll}
\hline Composition & $\begin{array}{l}\text { Diameter at breast } \\
\text { height }(\mathrm{cm})\end{array}$ & Height $(\mathrm{m})$ & $\begin{array}{l}\text { Fine litterfalla } \\
\left(\mathrm{kg} \mathrm{m}^{-2} \mathrm{yr}^{-1}\right)\end{array}$ & $\begin{array}{l}\text { Above-ground woody } \\
\text { biomass production } \\
\left(\mathrm{kg} \mathrm{m}^{-2} \mathrm{yr}^{-1}\right)\end{array}$ & $\begin{array}{l}\text { Above-ground net primary } \\
\text { production }\left(\mathrm{kg} \mathrm{m}^{-2} \mathrm{yr}^{-1}\right)\end{array}$ \\
\hline Beech & $50.6(4.5) \mathrm{a}$ & $31.6(1.2) \mathrm{a}$ & $0.49(0.03) \mathrm{a}$ & $0.44(0.09) \mathrm{a}$ & $0.93(0.09) \mathrm{a}$ \\
Oak & $45.0(2.5) \mathrm{b}$ & $27.1(0.8) \mathrm{b}$ & $0.36(0.02) \mathrm{b}$ & $0.44(0.09) \mathrm{a}$ & $0.80(0.10) \mathrm{a}$ \\
Hornbeam & $36.0(3.0) \mathrm{b}$ & $24.1(0.6) \mathrm{b}$ & $0.40(0.02) \mathrm{ab}$ & $0.33(0.09) \mathrm{a}$ & $0.73(0.10) \mathrm{a}$ \\
Lime & $35.9(2.4) \mathrm{b}$ & $26.1(1.1) \mathrm{b}$ & $0.28(0.02) \mathrm{c}$ & $0.43(0.09) \mathrm{a}$ & $0.70(0.10) \mathrm{a}$ \\
\hline
\end{tabular}

Means (SE, $n=6$ replicate stands) in each column with different letter indicate significant differences among mono-species stands (ANCOVA with Tukey HSD test at $\mathrm{P} \leqslant 0.05$ ).

aFine litterfall was measured in 2011 and 2012, above-ground woody biomass production (AWBP) was measured between 2012 and 2013, and above-ground net primary production was the sum of average annual fine litterfall and annual AWBP.

\subsubsection{Relative growth rates at stand and tree levels}

Relative growth rate at stand level ranged from $1.3 \times 10^{-3} \mathrm{~cm} \mathrm{~cm}^{-1} \mathrm{dbh}$ to $10.7 \times 10^{-3} \mathrm{~cm} \mathrm{~cm}^{-1} \mathrm{dbh}$ with a mean of $4.9 \times 10^{-3}\left( \pm 0.3 \times 10^{-3} \mathrm{SE}\right) \mathrm{cm} \mathrm{cm}^{-1} \mathrm{dbh}$. For mono-species stands, relative growth rates of lime and hornbeam were higher than those of beech and oak (Table 1.3). Relative growth rates between mono- and mix-species stands did not differ for any of the four species.

\section{Table 1.3}

Relative growth rates $(\mathrm{cm} \mathrm{cm}-1$ diameter at breast height $\times 10-3)$ of mono- and mix-species stands in an unmanaged deciduous forest in central Germany, measured from July 2012 to July 2013.

\begin{tabular}{llllll}
\hline Composition & & oa-ho-li & be-ho-li & be-oa-li & be-oa-ho \\
\hline Beech (be) & $3.6(0.6) \mathrm{B}, \mathrm{a}$ & $3.7(0.2)$ & $5.7(1.2)$ & $5.6(1.2)$ & $4.4(0.8)$ \\
Oak (oa) & $2.9(0.5) \mathrm{B}, \mathrm{a}$ & $\mathrm{a}$ & $\mathrm{a}$ & $\mathrm{a}$ & $\mathrm{a}$ \\
Hornbeam (ho) & $6.2(1.3) \mathrm{A}, \mathrm{a}$ & $\mathrm{a}$ & - & $\mathrm{a}$ & $\mathrm{a}$ \\
Lime (li) & $6.7(0.3) \mathrm{A}, \mathrm{a}$ & $\mathrm{a}$ & $\mathrm{a}$ & $\mathrm{a}$ & - \\
\hline
\end{tabular}

Means (SE, $n=6$ replicate stands) in the first column with different capital letter indicate significant differences among mono-species stands and different small letters in each row indicate significant differences among the mono-species stands and their corresponding mix-species stands (ANCOVA with Tukey HSD test at $P \leqslant 0.05$ ). Relative growth rates of $4-8$ trees per stand were averaged to represent each replicate stand. 
At tree level, relative growth rates of individual beech trees and lime trees were influenced by whether they were in mono-species stands or in mix-species stands. Individual beech trees of small dbh class $\left(0.1-0.4 \mathrm{~m}\right.$ dbh) grew slower $(P=0.03)$ in mono-species stands $\left(4.8 \times 10^{-3} \mathrm{~cm} \mathrm{~cm}^{-1} \mathrm{dbh}\right)$ than in beech-oak-lime $\left(14.3 \times 10^{-3} \mathrm{~cm} \mathrm{~cm}^{-1} \mathrm{dbh}\right)$ and beech-hornbeam-lime stands $\left(13.1 \times 10^{-3} \mathrm{~cm} \mathrm{~cm}^{-1} \mathrm{dbh}\right)$. Individual beech trees of large dbh class $(>0.4 \mathrm{~m} \mathrm{dbh})$ also grew slower $(P=0.05)$ in mono-species stands $\left(3.3 \times 10^{-3} \mathrm{~cm} \mathrm{~cm}^{-1} \mathrm{dbh}\right)$ than in beech-oak-hornbeam stands $\left(7.6 \times 10^{-3} \mathrm{~cm} \mathrm{~cm}^{-1} \mathrm{dbh}\right)$. On the other hand, individual lime trees grew faster $(P=0.09)$ in mono-species stands $\left(6.7 \times 10^{-3} \mathrm{~cm} \mathrm{~cm}^{-1} \mathrm{dbh}\right)$ than in the beech-oak-lime stands $\left(3.3 \times 10^{-3} \mathrm{~cm} \mathrm{~cm}^{-1} \mathrm{dbh}\right)$. Relative growth rates of individual oak and hornbeam trees did not differ whether they were in mono- or mix-species stands.

\subsubsection{Soil nutrient availability in mono- and mix-species stands}

For mono-species stands, plant-available $\mathrm{N}$ and exchangeable $\mathrm{K}$ in the soil did not differ among the four species (Table 1.4, clay content discounted in the statistical analysis; see Section 1.2.6). Plantavailable $\mathrm{P}$ was higher in hornbeam than in beech stands, and oak and lime stands had intermediate values. Exchangeable $\mathrm{Ca}$ in the soil was higher in lime than in hornbeam stands, with beech and oak stands not differing from these two stands (Table 1.4). For exchangeable Mg, differences among monospecies stands could not be statistically distinguished from the effect of soil texture as these two factors exhibited multicollinearity.

Comparing each mono-species stand with its corresponding mix-species stands, there were no differences in plant-available $\mathrm{N}$ and soil exchangeable Mg. Plant-available $\mathrm{P}$ was higher in oak mixed with hornbeam and lime (which as mono-species stands had the high and intermediate plant-available $\mathrm{P}$, respectively) than in oak mixed with beech (that had the lowest plant-available $\mathrm{P}$ as mono-species stand) and hornbeam (Table 1.4). Soil exchangeable $\mathrm{K}$ in oak mixed with hornbeam and lime was higher than in these species mixed with beech (Table 1.4). Soil exchangeable Ca was higher in mono-species lime stands than in lime mixed with hornbeam and beech (hornbeam having lower exchangeable Ca as mono-species stand) (Table 1.4). 


\section{Table 1.4}

Plant-available $\mathrm{N}$, plant-available $\mathrm{P}$ and exchangeable $\mathrm{K}, \mathrm{Ca}$ and $\mathrm{Mg}$ in the soil under mono- and mix-species stands in an unmanaged deciduous forest in central Germany, measured in the top 0.1-m depth in 2012.

\begin{tabular}{|c|c|c|c|c|c|}
\hline \multicolumn{2}{|l|}{ Composition } & oa-ho-li & be-ho-li & be-oa-li & be-oa-ho \\
\hline \multicolumn{6}{|c|}{ Plant-available $N \mathrm{a}\left(\mathrm{kg} \mathrm{N} \mathrm{ha}^{-1}\right.$ year-1) } \\
\hline & & $102.0(20.3)$ & $81.1(20.5)$ & $78.6(28.7)$ & $95.1(13.7)$ \\
\hline Beech (be) & 141.4 (29.9) A, a & - & a & a & a \\
\hline Oak (oa) & $92.2(44.9) \mathrm{A}, \mathrm{a}$ & a & - & a & a \\
\hline Hornbeam (ho) & 94.5 (33.9) A, a & a & a & - & a \\
\hline Lime (li) & 116.5 (26.6) A, a & a & a & a & - \\
\hline
\end{tabular}

Plant-available $P$ a $\left(k g P h a^{-1}\right)$

\begin{tabular}{llllll} 
& & $75.3(5.8)$ & $59.6(6.5)$ & $69.7(6.4)$ & $59.1(7.1)$ \\
Beech & $49.2(3.3) \mathrm{B}, \mathrm{a}$ & - & $\mathrm{a}$ & $\mathrm{a}$ & $\mathrm{a}$ \\
Oak & $62.1(4.2) \mathrm{AB}, \mathrm{ab}$ & $\mathrm{a}$ & - & $\mathrm{ab}$ & $\mathrm{b}$ \\
Hornbeam & $82.4(12.1) \mathrm{A}, \mathrm{a}$ & $\mathrm{a}$ & $\mathrm{a}$ & - & $\mathrm{a}$ \\
Lime & $60.4(3.2) \mathrm{AB}, \mathrm{a}$ & $\mathrm{a}$ & $\mathrm{a}$ & $\mathrm{a}$ & - \\
\hline
\end{tabular}

Exchangeable $\mathrm{K}\left(\mathrm{mmol}_{\mathrm{c}} \mathrm{Kg}^{-1}\right)$

\begin{tabular}{llllll} 
& & $6.1(0.4)$ & $4.7(0.8)$ & $4.7(0.3)$ & $3.5(0.5)$ \\
Beech & $3.3(0.4) \mathrm{A}, \mathrm{a}$ & - & $\mathrm{a}$ & $\mathrm{a}$ & $\mathrm{a}$ \\
Oak & $4.0(0.5) \mathrm{A}, \mathrm{ab}$ & $\mathrm{a}$ & - & $\mathrm{ab}$ & $\mathrm{b}$ \\
Hornbeam & $6.5(0.8) \mathrm{A}, \mathrm{a}$ & $\mathrm{a}$ & $\mathrm{ab}$ & - & $\mathrm{b}$ \\
Lime & $5.0(0.3) \mathrm{A}, \mathrm{a}$ & $\mathrm{a}$ & $\mathrm{a}$ & $\mathrm{a}$ & - \\
\hline
\end{tabular}

Exchangeable Ca $\left(\mathrm{mmol}_{\mathrm{c}} \mathrm{kg}^{-1}\right)$

$\begin{array}{llllll} & & 156.0(16.7) & 123.4(16.0) & 116.9(16.8) & 85.0(35.3) \\ \text { Beech } & 51.5(14.2) \mathrm{AB}, \mathrm{a} & - & \mathrm{a} & \mathrm{a} & \mathrm{a} \\ \text { Oak } & 47.2(18.5) \mathrm{AB}, \mathrm{a} & \mathrm{a} & - & \mathrm{a} & \mathrm{a} \\ \text { Hornbeam } & 185.3(69.4) \mathrm{B}, \mathrm{a} & \mathrm{a} & \mathrm{a} & - & \mathrm{a} \\ \text { Lime } & 197.1(35.8) \mathrm{A}, \mathrm{a} & \mathrm{ab} & \mathrm{b} & \mathrm{ab} & -\end{array}$

Exchangeable $\mathrm{Mg}{ }^{\circ}\left(\mathrm{mmol}_{\mathrm{c}} \mathrm{Kg}^{-1}\right)$

\begin{tabular}{llllll} 
& & $18.3(2.2)$ & $16.5(2.2)$ & $15.3(1.1)$ & $14.8(4.9)$ \\
Beech & $7.9(1.5) \mathrm{a}$ & - & $\mathrm{a}$ & $\mathrm{a}$ & $\mathrm{a}$ \\
Oak & $8.9(2.8) \mathrm{a}$ & $\mathrm{a}$ & - & $\mathrm{a}$ & $\mathrm{a}$ \\
Hornbeam & $17.0(2.8) \mathrm{a}$ & $\mathrm{a}$ & $\mathrm{a}$ & - & $\mathrm{a}$ \\
Lime & $19.6(1.4) \mathrm{a}$ & $\mathrm{a}$ & $\mathrm{a}$ & $\mathrm{a}$ & - \\
\hline
\end{tabular}

Means (SE, $n=6$ replicate stands) in the first column with different capital letter indicate significant differences among mono-species stands and different small letters in each row indicate significant differences among the mono-species stands and their corresponding mix-species stands (ANCOVA with Tukey HSD test at $P \leqslant 0.05$ for $\mathrm{N}$ and $\mathrm{Mg}$ and at $P \leqslant 0.09$ for $\mathrm{K}$ and Ca; linear mixed effects model at $P \leqslant 0.05$ for $\mathrm{P}$ ).

aFor plant-available $\mathrm{N}$ and $\mathrm{P}$, mass-based concentrations were expressed on area basis using the average soil bulk density of $1.21 \pm$ $0.02 \mathrm{~g} \mathrm{~cm}-3$ measured in the top $0.1 \mathrm{~m}$.

bDifferences in soil exchangeable Mg between mono-species stands cannot be tested using ANCOVA because of multicollinearity, i.e., effect of different mono-species stands cannot be statistically distinguished from that of soil texture. 


\subsubsection{Growth curves and nutrient response efficiency curves}

Here, we reported only the species (i.e., beech, oak and their corresponding mix-species stands) that showed significant differences in relative growth rates, soil nutrient availability, NRE and/or a norelationship between growth and a soil nutrient element (Eq. (1.3)) but statistical analyses were conducted for all mono- and mix-species stands. At tree level, relative growth rates of individual beech trees were influenced by the levels of plant-available $P(P=0.01)$ (Fig. 1.2a) and exchangeable $\mathrm{K}$ in the soil $(P=0.03)$ (Fig. 1.2c). Individual beech trees in mono-species stands, which had the lowest levels of these two soil nutrient elements (Table 1.4), had lower relative growth rates than beech trees in mixspecies stands (Fig. 1.2a and c). Using the tree-level relative growth rates, a unimodal NRE curve was the best fit for both plant-available $\mathrm{P}(P=0.04)$ (Fig. 1.2b) and soil exchangeable $\mathrm{K}(P=0.01)$ (Fig. 1.2d). Individual beech trees in mono-species stands were located on the low side (i.e., left slope of Fig. 1.1) whereas beech trees in mix-species stands were on the peak (i.e., optimum NRE of Fig. 1) of the NRE curve for plant-available $\mathrm{P}$ (Fig. 1.2b). For soil exchangeable $\mathrm{K}$, beech trees in mono-species stands (low $\mathrm{K}$ levels, Table 1.4) and in mix stands with oak and hornbeam (low to intermediate K levels, Table 1.4) were below the optimum NRE whereas beech trees in mix stands with lime and either oak or hornbeam (high K levels, Table 1.4) were beyond the optimum NRE (Fig. 1.2d) (i.e., slightly towards saturation of Fig. 1.1).

At tree level, relative growth rates of individual oak trees in mono- and mix-species stands were not related to exchangeable $\mathrm{K}$ in the soil (Fig. 1.3a), at least in the range that we measured. Such a constant relative growth rate within our observed range of exchangeable $\mathrm{K}$ (Eq. (1.3)) resulted in a decrease of $\mathrm{K}$ response efficiency with increasing exchangeable $\mathrm{K}(P=0.03)$ (Fig. 1.3b). 

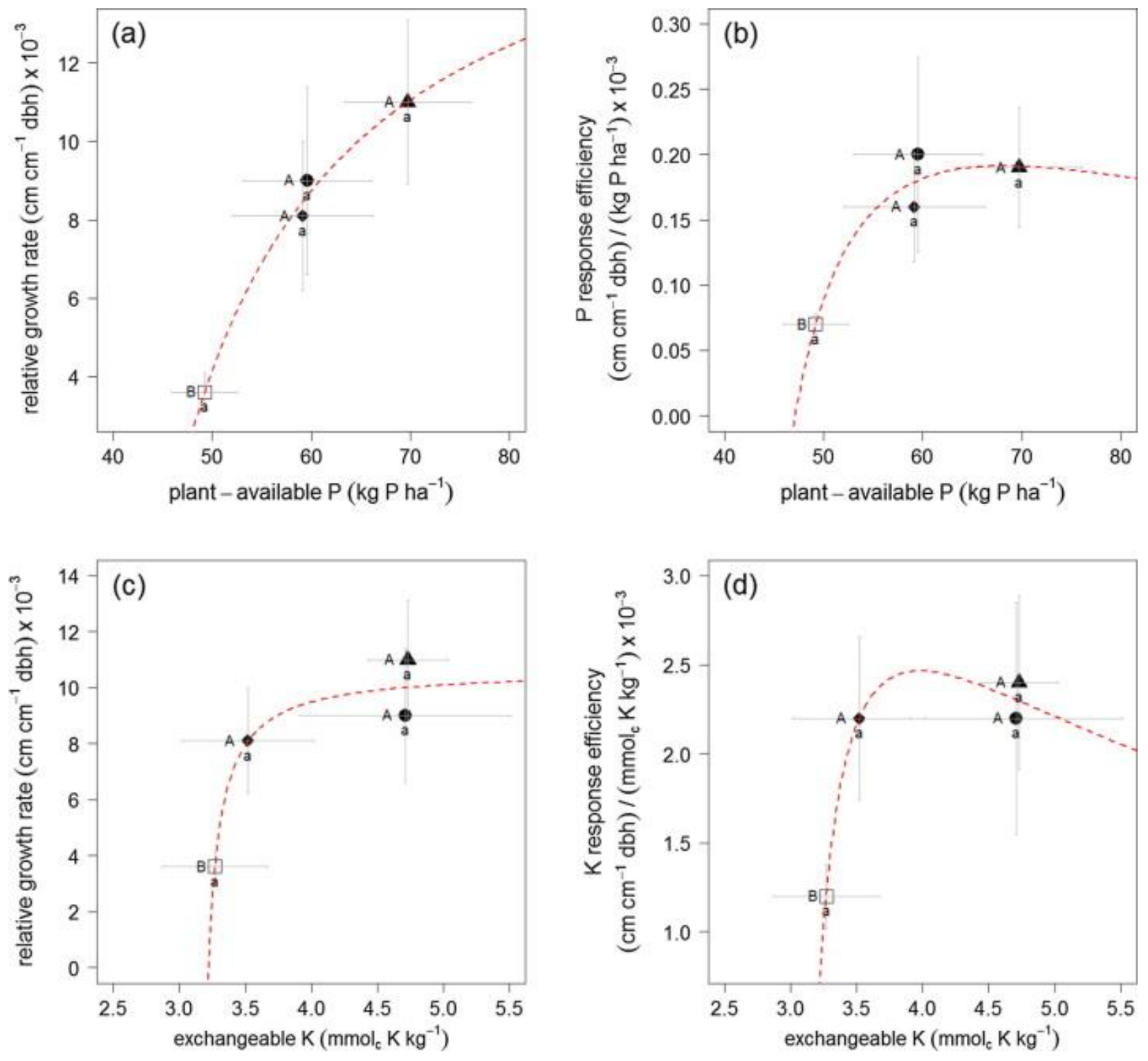

Fig. 1.2

Relative growth rate $(R G R)(a, c)$ and nutrient response efficiency (NRE) (b, d) with plant-available phosphorus (P) (i.e., resinexchangeable $+\mathrm{NaHCO}_{3}$-extractable $\mathrm{P}$ ) and exchangeable potassium (K) in mono-species beech stands and its corresponding mixspecies stands. Means (SE bars) with different small letters indicate significant differences on the $x$-axis and means with different capital letters indicate significant differences on the $y$-axis (ANCOVA with Tukey HSD test at $P \leqslant 0.05$ except for RGR and NRE where $P=0.03-0.08$ ). Growth (Eq. (1.1)) and NRE (Eq. (1.2)) curves were modeled using the nonlinear least square method ( $P=0.01-0.04$, Pearson correlation tests between fitted and observed values). For RGR at tree level, means are average of $n=26$ beech trees in mono-species stands $(\square), 8$ beech trees in beech-hornbeam-lime stands $(\bullet), 7$ beech trees in beech-oak-lime stands $(\wedge)$, and 8 beech trees in beech-oak-hornbeam stands $(\diamond)$ stands; for soil nutrients, $n=6$ replicate stands for each mono- and mixspecies. 

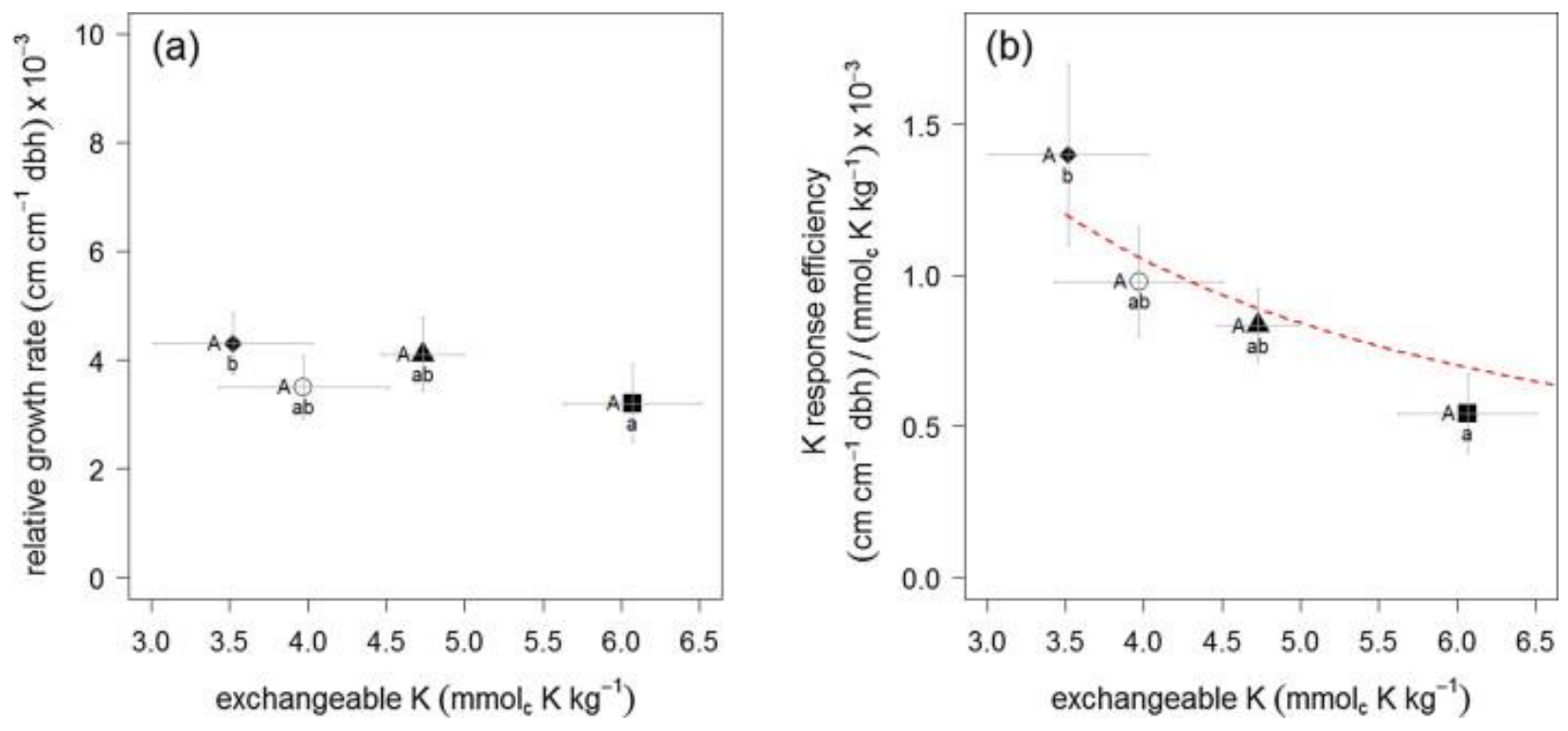

Fig. 1.3

Relative growth rate (RGR) (a) and nutrient response efficiency (NRE) (b) with exchangeable potassium (K) in mono-species oaks stand and its corresponding mix-species stands. Means (SE) with different small letters indicate significant differences on the $x$-axis and means with different capital letters indicate significant differences on the $y$-axis (ANCOVA with Tukey HSD test at $P \leqslant 0.05$ ). No relationship (Eq. (1.3)) existed between RGR and exchangeable K. The NRE curve (Eq. (1.2)) was modeled using the nonlinear least square method ( $P=0.03$, Pearson correlation tests between fitted and observed values). For RGR at tree level, means are average of $n=17$ oak trees as mono-species stands ( ()$, 6$ oak trees in oak-hornbeam-lime stands ( $\bullet$ ), 8 oak trees in beech-oak-lime stands $(\triangleleft)$, and 6 oak trees in beech-oak-hornbeam stands $(\bullet)$; for exchangeable $\mathrm{K}, n=6$ replicate stands for each mono- and mixspecies.

\subsection{Discussion}

\subsubsection{Productivity and soil nutrient availability at a stand level}

In contrast to our first hypothesis, mix-species stands showed relative growth rates within the range of the mono-species stands of the contributing species (Table 1.3). At a stand level, these results showed no indications of species diversity effects. Our results support that of an earlier study conducted near our study area (Seidel et al. 2013) that found no relationship between ANPP and tree species richness. Both our and Seidel et al. (2013) results contrast with a previous study, conducted also near our study area, that reported a decreasing ANPP with decreasing abundance of beech (Jacob et al. 2010) and this we attribute to (1) the use of absolute values of stem diameter increment in plots that have inherently large dbh beech trees (as present in our study area; Table 1.2), and (2) an experimental design that mainly compared different abundances of beech but not with stands of other species. 
Nutrient availability in soils of mix-species stands was attributable to the tree species contributing to the mix. Clearly, when oak was mixed with hornbeam and lime there were positive effects on plant-available $\mathrm{P}$ and exchangeable $\mathrm{K}$, but when lime was mixed with beech and hornbeam there was a negative effect on exchangeable Ca in the soil (Table 1.4), although these did not affect the productivity at the stand level. Similar results were reported in a review, where neither soil N pools, $\mathrm{P}$ levels nor the levels of exchangeable cations in the soil were affected by species mixtures compared to mono-species (Rothe and Binkley 2001). The studies included in this review, however, were not limited to the temperate forests and the mix-species stands of temperate species included $\mathrm{N}$-fixing alder and coniferous species.

\subsubsection{Nutrient limitation and nutrient response efficiency at tree level}

Whereas tree species diversity effects could not be detected at a stand level, analyzing the performance of individual trees within different stand compositions using the neighborhood approach (Rothe and Binkley 2001) enabled us to detect differences in productivity and NRE of trees between mono- and mix-species stands. Plant-available $\mathrm{N}$ did not limit tree growth in any of the studied tree species. Instead we found that plant-available $\mathrm{P}$ and exchangeable soil $\mathrm{K}$ were limiting growth of beech trees as shown by the significant curve fits of beech's relative growth rate and NRE with these soil nutrient elements (Fig. 1.2). While beech trees in mix-species stands displayed an optimal $\mathrm{P}$ response efficiency, beech trees in mono-species stands showed $\mathrm{P}$ limitation (Fig. 1.2b). Based on nutrient concentrations in sun-exposed leaves, an earlier study also suggests partial P-deficiency in pure beech forests in Germany (Ilg et al. 2009). Also, the K response efficiencies of beech trees in mix-species stands were close to optimum unlike those in mono-species stands (Fig. 1.2d), indicating that $\mathrm{K}$ was a limiting nutrient element in mono-species beech stands. K deficiency has been described for other tree species, e.g., Pinus sylvestris in Germany, Finland and Sweden, and Acer saccharum in the USA and Canada (Tripler et al. 2006), but to our knowledge this is the first time that $\mathrm{K}$ deficiency has been shown for mature beech trees. This $\mathrm{K}$ deficiency may be related to the high $\mathrm{K}$ content in beech seeds, indicating high $\mathrm{K}$ demand of beech, together with increased frequency of years that beech produce seeds, which was observed in recent years (Paar et al. 2011). Furthermore, enhanced nitrate leaching as a result of $\mathrm{N}$ deposition may have contributed to leaching of $\mathrm{K}$ and other base cations and deteriorated $\mathrm{K}$ availability as was shown for beech stands in France (Thimonier et al. 2000). As opposed to beech, oak trees showed a non-relationship (i.e., constant growth) between relative growth rates and the range of exchangeable $\mathrm{K}$ levels in the soil we measured (Fig. 1.3a), indicating that $\mathrm{K}$ was not the limiting nutrient for oak growth but that K levels were at the surplus side for the demand of oak growth (Pastor and Bridgham 1999). This 
was also supported by the $\mathrm{K}$ response efficiencies (Fig. 1.3b), which fell at far right of optimal efficiency (Fig. 1.1).

Other than these species and soil nutrients mentioned above, there were no significant relationships detected between relative growth rate or NRE with other soil nutrients. We deduct that oak, hornbeam and lime were not limited by any of the soil nutrients we measured and their productivity may be dependent on other factors (such as water availability and/or light), which were not included in our investigation.

We did not detect a mixture of tree species for which one or more nutrients were growthlimiting to all the contributing species. In contrast, the NRE curves we observed were a limitation or saturation of a specific nutrient (Bridgham et al. 1995 and Pastor and Bridgham 1999), which supports our second hypothesis. In such case when nutrient limitation is species-dependent, calculating NRE at a stand-level is not applicable since NRE of a forest stand is an additive function of each species' nutrient response curve and the stand's average nutrient availability. NRE curves for whole stands make sense only when multiple species in the stands are limited by the same nutrient. Fitting one NRE curve for different tree-communities has been done in nutrient availability gradients and in nutrient-deficient soils of the tropics (Bridgham et al. 1995), but this is unlikely to be successful when nutrient limitation differs for the contributing species.

\subsubsection{Facilitation, complementarity and competition between tree species}

Whereas facilitation, complementarity and competition are co-occurring processes, there was no indication for complementarity since there was no mixture where two or more species profited together. However, individual beech trees were able to respond with higher relative growth rates to enhanced amounts of plant-available $\mathrm{P}$ and exchangeable $\mathrm{K}$ in the soil when in mix-species stands (Fig. 1.2a and c), particularly with hornbeam and/or lime which were the mono-species stands that showed high levels of these soil nutrients. Thus, for beech trees in mix-species stands, facilitation dominated over competition. Using planted seedlings, it has also been shown that Picea could profit from the presence of Alnus (Chapin et al. 1994); however, this is not surprising since Alnus is able to fix $\mathrm{N}$ which was a limiting nutrient for Picea growth. To our knowledge, we were able to show for the first time facilitation through soil nutrient availability between mature trees that do not fix $\mathrm{N}$ in a deciduous forest stand. Beech has been shown to tolerate a wide range of soil nutrient availability (Leuschner et al. 2006). The ability of beech to take advantage of nutrients provided by other tree species might be a key factor contributing to its dominance in Central European deciduous forests. 
In contrast to beech, individual lime trees had the tendency to grow faster when in monospecies stands than when surrounded by beech and oak (see Section 1.3.2 above). This may be explained by the generally favorable soil biochemical characteristics of mono-species lime stands (Table 1.1). Overall, this suggests that for individual lime trees competition dominated over facilitation and/or complementarity when growing in mix-species stands.

In summary, our third hypothesis (i.e., mix-species stands use soil available nutrients more efficiently than mono-species stands) was not supported when data analysis was conducted at a stand level. However, by using a neighborhood approach (i.e., data analysis at tree level), our results showed that beech trees were more productive in mix-species stand whereas lime trees were less productive in mix-species stands.

\subsubsection{Considering neighborhood interaction in forest management}

In managed forests in Germany, tree species are selected based on a comprehensive analysis of geographical setting, climate, vegetation and soil (AK Standortkartierung 2003). However, this analysis does not take into account the potential effects of direct neighborhood on tree growth and NRE. Our results showed that direct neighborhood of certain species can increase a species' productivity and improve NRE in temperate forest stands. Such effects may be considered when managing mix-species stands. For example, in sites with comparable conditions to our study, high productivity of beech trees can be achieved when they are grown in direct neighborhood of hornbeam and/or lime trees, possibly due to high plant-available $\mathrm{P}$ (as shown in mono-species stands of hornbeam, Table 1.4) and/or favorable soil biochemical characteristics (evident from mono-species stands of lime, Table 1.1); when beech was in a stand with oak (that had low soil nutrient levels comparable to beech in mono-species stands, Table 1.4) high productivity may be attained when in combination with either lime or hornbeam (see Section 1.3.2 above). Furthermore, lime profits when grown in clusters, probably due to favorable soil biochemical conditions (Table 1.1) in mono-species stands of lime and possibly due to less competition for nutrients from other tree species. Since we were able to show this effect on the small-scale plots of our study, it would be sufficient that patches of lime include a minimum of four trees. Since oak and hornbeam trees within the mix-species stands were not affected by neighboring trees, they can be planted either in patches of their own or in mixtures with beech. Since our study included relatively mature oak trees and relatively small hornbeam trees, these findings may be different for small-diameter oak trees and large-diameter hornbeam trees. 


\subsection{Conclusions}

Knowledge on how an individual tree species performs in the presence of others, through quantification of the changes in growth or NRE with different soil nutrient levels, gives insight into the complex interactions of mix-species stands. We were able to show that nutrient limitation in this temperate forest was species-dependent with no tree species limited by N. Growth of individual beech trees, which was limited by $\mathrm{P}$ and $\mathrm{K}$ in mono-species stands, was facilitated by enhanced levels of $\mathrm{P}$ and $\mathrm{K}$ in mix-species stands. Our findings may open opportunities to enhance management of such stands. Given the high number of possible species combinations on different soil types, there are likely more facilitation, complementarity and competition effects than those observed in our study. If we want to include such interaction in management decisions, the next step would be to link them to functional traits which would open the possibility to predict such interactions.

\section{Acknowledgments}

This study was part of the Research Training Group 1086/2-3 (The role of biodiversity for biogeochemical cycles and biotic interactions in temperate deciduous forests) Subproject B7, funded by the German Research Foundation (DFG). We would like to thank the Hainich national park authorities for allowing us access to the study site. Thanks to our many technical assistants for the help in the laboratory analyses and to Frederic Fischer, Johannes Persch and Wiebke Schrell, who conducted their BSc thesis under our project's theme.

\section{References}

AK Standortkartierung, 2003. Forstliche Standortsaufnahme. Niedersächsische Forstliche Versuchsanstalt. Göttingen, Germany.

Blake, G.R., Hartge, K.H., 1986. Bulk density, in: Klute, A. (Ed.). Methods of Soil Analysis, Part 1. Physical and Mineralogical Methods. American Society of Agronomy, Soil Science Society of America, Madison, WI, 263-376.

Braun, S., Thomas, V. F., Quiring, R., Flückiger, W., 2010. Does nitrogen deposition increase forest production? The role of phosphorus. Environmental Pollution 158, 2043-2052.

Bridgham, S. D., Pastor, J., McClaugherty, C. A., Richardson, C. J., 1995. Nutrient-use efficiency: a litterfall index, a model, and a test along a nutrient-availability gradient in North Carolina peatlands. American Naturalist $145,1-21$.

Builtjes, P., Hendriks, E., Koenen, M., Schaap, M., Banzhaf, S., Kerschbaumer, A. Gauger, T., Nagel, H.D. Scheuschner, T., Schlutow, A., 2011. Erfassung, Prognose und Bewertung von Stoffeinträgen und ihren Wirkungen in Deutschland-Zusammenfassender Abschlussbericht. Umweltbundesamt. Dessau-Rosslau, Germany. Appendix 11. 
Bunce, R. G. H., 1968. Biomass and production of trees in a mixed deciduous woodland: I. Girth and height as parameters for the estimation of tree dry weight. The Journal of Ecology 56, 759-775.

Callaway, R. M., Nadkarni, N. M., Mahall, B. E., 1991. Facilitation and interference of Quercus douglasii on understory productivity in central California. Ecology 72, 1484-1499.

Chapin III, F. S., Vitousek, P. M., Van Cleve, K., 1986. The nature of nutrient limitation in plant communities. American Naturalist 127, 48-58.

Chapin III, F. S., Walker, L. R., Fastie, C. L., Sharman, L. C., 1994. Mechanisms of primary succession following deglaciation at Glacier Bay, Alaska. Ecological Monographs 64, 149-175.

Chisholm, R.A., Muller-Landau, H.C., Abdul Rahman, K., Bebber, D.P., Bin, Y., Bohlman, S.A., Bourg, N.A., Brinks, J., Bunyavejchewin, S., Butt, N., Cao, H.L., Cao, M., Cardenas, D., Chang, L.W., Chiang, J.M., Chuyong, G., Condit, R., Dattaraja, H.S., Davies, S., Duque, A., Fletcher, C., Gunatilleke, N., Gunatilleke, S., Hao, Z.Q., Harrison, R.D., Howe, R., Hsieh, C.F., Hubbell, S.P., Itoh, A., Kenfack, D., Kiratiprayoon, S., Larson, A.J., Lian, J.Y., Lin, D.M., Liu, H.F., Lutz, J.A., Ma, K.P., Malhi, Y., McMahon, S., McShea, W., Meegaskumbura, M., Razman, S.M., Morecroft, M.D., Nytch, C.J., Oliveira, A., Parker, G.G., Pulla, S., Punchi-Manage, R., Romero-Saltos, H., Sang, W.G., Schurman, J., Su, S.H., Sukumar, R., Sun, I.F., Suresh, H.S., Tan, S., Thomas, D., Thomas, S., Thompson, J., Valencia, R., Wolf, A., Yap, S., Ye, W.H., Yuan, Z.Q., Zimmerman, J.K., 2013. Scale-dependent relationships between tree species richness and ecosystem function in forests. Journal of Ecology 101, 1214-1224.

Cienciala, E., Apltauer, J., Exnerová, Z., Tatarinov, F., 2008. Biomass functions applicable to oak trees grown in Central-European forestry. Journal of Forest Science 54, 109-120.

Corre, M. D., Beese, F. O., Brumme, R., 2003. Soil nitrogen cycle in high nitrogen deposition forest: changes under nitrogen saturation and liming. Ecological Applications 13, 287-298.

Corre, M. D., Brumme, R., Veldkamp, E., Beese, F. O., 2007. Changes in nitrogen cycling and retention processes in soils under spruce forests along a nitrogen enrichment gradient in Germany. Global Change Biology 13, 1509-1527.

Cross, A. F., Schlesinger, W. H., 1995. A literature review and evaluation of the Hedley fractionation: Applications to the biogeochemical cycle of soil phosphorus in natural ecosystems. Geoderma 64, 197-214.

Crawley, M. J., 2002. The R Book. Wiley, Chichester.

de Mendiburu, F., 2014. agricolae: Statistical Procedures for Agricultural Research. R package version 1.2-1. http://CRAN.R-project.org/package=agricolae

Fridley, J. D., 2001. The influence of species diversity on ecosystem productivity: how, where, and why?. Oikos 93, 514-526.

Fox, J., Weisberg, S., 2011. An \{R\} Companion to Applied Regression, Second Edition. Thousand Oaks, CA: Sage. http://socserv.socsci.mcmaster.ca/jfox/Books/Companion

Giraudoux, P., 2014. pgirmess: Data analysis in ecology. R package version 1.5.9. http://CRAN.Rproject.org/package=pgirmess

Hart, S.C., Stark, J.M., Davidson, E.A., Firestone, M.K., 1994. Nitrogen mineralization, immobilization, and nitrification. in: Weaver, R. (Ed.). Methods of Soil Analysis, Part 2. Microbiological and Biochemical Properties. Soil Science Society of America, Madison, WI, 985-1019.

Hedin, L. O., Armesto, J. J., Johnson, A. H., 1995. Patterns of nutrient loss from unpolluted, old-growth temperate forests: evaluation of biogeochemical theory. Ecology 76, 493-509.

Hooper, D. U., Chapin III, F. S., Ewel, J. J., Hector, A., Inchausti, P., Lavorel, S., Lawton, J.H., Lodge, D.M., Loreau, M., Naeem, S., Schmid, B., Setala, H., Symstad, A.J., Vandermeer, J. Wardle, D. A., 2005. Effects of biodiversity on ecosystem functioning: a consensus of current knowledge. Ecological Monographs 75, 335.

Hothorn, T., Bretz, F., Westfall, P., 2008. Simultaneous Inference in General Parametric Models. Biometrical Journal 
$50,346-363$.

Ilg, K., Wellbrock, N., Lux, W., 2009. Phosphorus supply and cycling at long-term forest monitoring sites in Germany. European Journal of Forest Research 128, 483-492.

Jacob, M., Leuschner, C., Thomas, F. M., 2010. Productivity of temperate broad-leaved forest stands differing in tree species diversity. Annals of Forest Science 67, 503

Leuschner, C., Meier, I. C., Hertel, D., 2006. On the niche breadth of Fagus sylvatica: soil nutrient status in 50 Central European beech stands on a broad range of bedrock types. Annals of Forest Science 63, 355-368.

Loreau, M., Naeem, S., Inchausti, P., Bengtsson, J., Grime, J. P., Hector, A., Hooper, D.U., Huston, M.A., Raffaelli, D., Schmid, B., Tilman, D., Wardle, D. A., 2001. Biodiversity and ecosystem functioning: current knowledge and future challenges. Science 294, 804-808.

Mead, R., 1966. A relationship between individual plant-spacing and yield. Annals of Botany 30, 301-309.

Mölder, A., Bernhard-Römermann, M., and Schmidt, W., 2006. Forest ecosystem research in Hainich National Park (Thuringia): first results on flora and vegetation in stands with contrasting tree species diversity, Waldökologie online 3, 83-99.

Monod, J., 1942. Recherches sur la croissance des cultures bacteriennes. Hermann, Paris.

Morin, X., Fahse, L., Scherer-Lorenzen, M., Bugmann, H., 2011. Tree species richness promotes productivity in temperate forests through strong complementarity between species. Ecology Letters 14, 1211-1219.

Nationalparkverwaltung Hainich, 2008. Wälder im Nationalpark Hainich. Ergebnisse der 1. permanenten Stichprobeninventur 1999-2001. Erforschen Band 1. Nationalparkverwaltung Hainich. Bad Langensalza, Germany.

Paar, U., Guckland, A., Dammann, I., Albrecht, M., Eichhorn, J., 2011. Häufigkeit und Intensität der Fruktifikation der Buche. AFZ-Der Wald 6, 26-29.

Page, A.L., Miller R.H. Keeney D.R. (Eds.), 1994. Methods of soil analysis. Part 2. Chemical and Microbiological Properties. American Society of Agronomy, Madison, Wisconsin.

Paquette, A., Messier, C., 2011. The effect of biodiversity on tree productivity: from temperate to boreal forests. Global Ecology and Biogeography 20, 170-180.

Pastor, J., Bridgham, S. D., 1999. Nutrient efficiency along nutrient availability gradients. Oecologia 118, 50-58.

Pinheiro J., Bates D., DebRoy S., Sarkar D., R Core Team, 2014. nlme: Linear and Nonlinear Mixed Effects Models. R package version 3.1-117. http://CRAN.R-project.org/package=nlme

Piotto, D., 2008. A meta-analysis comparing tree growth in monocultures and mixed plantations. Forest Ecology and Management 255, 781-786.

Pretzsch, H., 2003. Diversität und Produktivität von Wäldern. Allgemeine Forst-und Jagdzeitung 174, 88-98.

QGIS Development Team, 2012. QGIS Geographic Information System. Open Source Geospatial Foundation Project. http://qgis.osgeo.org

R Development Core Team, 2013. R: A language and environment for statistical computing. R Foundation for Statistical Computing, Vienna, Austria. http://www.r-project.org.

Rajendra, K. C., 2009. Species identification in Tilia: a genetic approach, M. Sc. thesis. Georg-August-University, Göttingen, Germany.

Rothe, A., Binkley, D., 2001. Nutritional interactions in mixed species forests: a synthesis. Canadian Journal of Forest Research 31, 1855-1870.

Seidel, D., Leuschner, C., Scherber, C., Beyer, F., Wommelsdorf, T., Cashman, M. J., Fehrmann, L., 2013. The relationship between tree species richness, canopy space exploration and productivity in a temperate broad-leaf mixed forest. Forest Ecology and Management 310, 366-374. 
Spiess, A. N., Neumeyer, N., 2010. An evaluation of $\mathrm{R}^{2}$ as an inadequate measure for nonlinear models in pharmacological and biochemical research: a Monte Carlo approach. BMC pharmacology 10, 6.

Thimonier, A., Dupouey, J. L., Le Tacon, F., 2000. Recent losses of base cations from soils of Fagus sylvatica L. stands in northeastern France. Ambio 314-321.

Tiessen, H., Moir, J. O., 1993. Characterization of available P by sequential extraction, in: Carter, M.R. (Ed.). Soil Sampling and Methods of Analysis. Canadian Society of Soil Science, Lewis Publishers, 75-86.

Tilman, D., Reich, P. B., Isbell, F., 2012. Biodiversity impacts ecosystem productivity as much as resources, disturbance, or herbivory. Proceedings of the National Academy of Sciences 109, 10394-10397.

Tripler, C. E., Kaushal, S. S., Likens, G. E., Todd Walter, M., 2006. Patterns in potassium dynamics in forest ecosystems. Ecology Letters 9, 451-466.

Vandermeer, J., 1989. The ecology of intercropping, Cambridge University Press, Cambridge.

Vilà, M., Inchausti, P., Vayreda, J., Barrantes, O., Gracia, C., Ibáñez, J. J., Mata, T., 2005. Confounding factors in the observational productivity-diversity relationship in forests, in: Scherer-Lorenzen, M., Körner, C., Schulze, E.-D. (Eds.), Forest Diversity and Function (pp. 65-86). Springer, Berlin and Heidelberg.

Vilà, M., Vayreda, J., Comas, L., Ibáñez, J. J., Mata, T., Obón, B., 2007. Species richness and wood production: a positive association in Mediterranean forests. Ecology Letters 10, 241-250.

Vitousek, P., 1982. Nutrient cycling and nutrient use efficiency. American Naturalist 119, 553-572.

Wirth, C., Schulze, E. D., Schwalbe, G., Tomczyk, S., Weber, G., Weller, E., 2004. Dynamik der Kohlenstoffvorräte in den Wäldern Thüringens. Mitteilungen 23/2004. Thüringer Ministerium für Landwirtschaft Naturschutz und Umwelt. Erfurt, Germany.

Yamashita, N., Ohta, S., Hardjono, A., 2008. Soil changes induced by Acacia mangium plantation establishment: Comparison with secondary forest and Imperata cylindrica grassland soils in South Sumatra, Indonesia. Forest Ecology and Management 254, 362-370. 


\section{Appendix 1.I}

Soil texture in mono- and mix-species stands in an unmanaged deciduous forest in central Germany, measured in the top 0.1-m depth in 2012.

\begin{tabular}{|c|c|c|c|c|c|}
\hline composition & $\begin{array}{l}\text { sand / silt / clay } \\
\%\end{array}$ & oa-ho-li & be-ho-li & be-oa-li & be-oa-ho \\
\hline & & $1.3 / 65.6 / 33.1$ & $1.0 / 65.4 / 33.9$ & $1.5 / 70.8 / 27.7$ & $1.4 / 74.7 / 23.9$ \\
\hline beech (be) & $\begin{array}{l}1.4 \text { / } 81.0 / 17.6 \\
\text { a / a / a } \\
\text { A / A / C }\end{array}$ & - & $\mathrm{b} / \mathrm{a} / \mathrm{a}$ & $\mathrm{a} / \mathrm{a} / \mathrm{a}$ & $\mathrm{a} / \mathrm{a} / \mathrm{a}$ \\
\hline oak (oa) & $\begin{array}{l}1.5 / 76.5 / 22.0 \\
\mathrm{a} / \mathrm{a} / \mathrm{a} \\
\mathrm{A} / \mathrm{AB} / \mathrm{BC}\end{array}$ & $\mathrm{a} / \mathrm{a} / \mathrm{a}$ & - & $\mathrm{a} / \mathrm{a} / \mathrm{a}$ & $\mathrm{a} / \mathrm{a} / \mathrm{a}$ \\
\hline hornbeam (ho) & $\begin{array}{l}1.3 / 63.2 / 35.5 \\
a b / a / a \\
A / C / A\end{array}$ & $\mathrm{~b} / \mathrm{a} / \mathrm{a}$ & $\mathrm{a} / \mathrm{a} / \mathrm{a}$ & - & $\mathrm{a} / \mathrm{a} / \mathrm{a}$ \\
\hline lime (li) & $\begin{array}{l}1.6 / 67.9 / 30.6 \\
\mathrm{a} / \mathrm{a} / \mathrm{a} \\
\mathrm{A} / \mathrm{BC} / \mathrm{AB}\end{array}$ & $\mathrm{ab} / \mathrm{a} / \mathrm{a}$ & $\mathrm{b} / \mathrm{a} / \mathrm{a}$ & $\mathrm{a} / \mathrm{a} / \mathrm{a}$ & - \\
\hline
\end{tabular}

Means ( $n=3$ stands) with different capital letter in the first column indicate significant differences among mono-species stands for each soil texture fraction, and means with different small letter in each row indicate significant differences between the mono-species stand and its corresponding mix-species stands (one-way ANOVA with least significant difference test or Kruskal-Wallis test with multiple comparison extension at $P \leq 0.05$, except for hornbeam and its mix-species stands where $P \leq 0.09$ and for lime and its mixspecies stands where $P \leq 0.06$ ). 
Chapter 2 


\title{
2. Tree-microbial biomass competition for nutrients in a temperate deciduous forest, central Germany
}

\author{
Marcus Schmidt, Edzo Veldkamp, Marife D. Corre \\ Submitted to Plant and Soil, October 20, 2015
}

\section{Abstract}

Aims

Our goals were (1) to determine whether tree species diversity affects nutrient (N, $\mathrm{P}$ and $\mathrm{K}$ ) cycling, and (2) to assess whether there is competition for these nutrients between microbial biomass and trees.

\section{Methods}

We measured nutrient resorption efficiency by trees, nutrient contents in leaf litterfall, decomposition rates of leaf litter, nutrient turnover in decomposing leaf litter, and plant-available nutrients in the soil in mono-species stands of beech, oak, hornbeam and lime and in mixed-species stands of three of these species.

\section{Results}

Cycling of nutrients through leaf litter input and decomposition were influenced by the types of tree species and not simply by tree species diversity. Trees and microbial biomass were competing strongly for $\mathrm{P}$, less for $\mathrm{K}$ and only marginally for $\mathrm{N}$. Such competition was most pronounced in mono-species stands of beech and oak, which had low nutrient turnover in their slow decomposing leaf litter, and less in mono-species stands of hornbeam and lime, which had high nutrient turnover in their fast decomposing leaf litter.

\section{Conclusions}

The low soil P and K availability in beech stands, which limit the growth of beech at Hainich, Germany, were alleviated by mixing beech with hornbeam and lime. These species-specific effects on nutrient cycling and soil nutrient availability can aid forest management in improving productivity and soil fertility. 


\section{Keywords}

decomposition rate, leaf litter nutrient content, leaf litter nutrient turnover, nutrient resorption efficiency, tree species diversity

\subsection{Introduction}

During annual leaf senescence of deciduous forest ecosystems, foliar nutrients are apportioned into two pathways: a) litterfall followed by decomposition, and b) resorption by trees (Aerts 1997). Leaf litterfall generally constitutes close to $80 \%$ of total litterfall in broadleaf European temperate forests (Liu et al. 2004), and leaf litter decomposition is a major process contributing to nutrient cycling and nutrient retention in ecosystems (Prescott 2010). The microbial biomass plays a key role in leaf litter decomposition, as it assimilates and transfers organic matter, nutrients and energy from the litter to the soil. Microbial activity on the leaf litter (as substrate) depends on its carbon (C):nutrient ratio, in addition to the influence of external abiotic factors. If nitrogen $(\mathrm{N})$ is abundant and the $\mathrm{C}: \mathrm{N}$ ratio of the decomposing leaf litter is low, net $\mathrm{N}$ release (or net $\mathrm{N}$ mineralization) to the soil results (Chapin III et al. 2011). In contrast, if microbial biomass requires larger amounts of nutrients than provided by the decomposing litter, assimilation (or net nutrient immobilization) of nutrients from the soil takes place. Net $\mathrm{N}$ immobilization is commonly reported for decomposing leaf litter, whereas for phosphorus $(\mathrm{P})$ both net mineralization and immobilization have been shown to occur (Prescott 2005). In the second pathway for foliar nutrients, resorption of nutrients from the leaves prior to senescence acts as an important mechanism for reducing the losses of nutrients from trees in nutrient-poor environments (Osman 2013). In a review, deciduous shrubs and trees of different biomes resorbed on average $54 \% \mathrm{~N}$ and $50 \% \mathrm{P}$ of foliar $\mathrm{N}$ and $\mathrm{P}$ concentrations, which are not related to the availability of these nutrients in the soil (Aerts 1996). However, decreasing $\mathrm{N}$ and $\mathrm{P}$ resorption with increasing leaf nutrient concentrations have been observed for perennial plants (Kobe et al. 2005), a finding that was also supported by a recent study showing that, on a global scale, woody plants resorb proportionally more of a growth-limiting nutrient than of nutrients not limiting plant growth (Han et al. 2013).

Nutrients from leaf litter decomposition can be assimilated by microbial biomass, taken up by plants and retained in the soil. As long as nutrients are limiting plant growth and microbial biomass metabolism, competition for these resources is expected. For example, this has been shown for $\mathrm{N}$ in an unpolluted old-growth temperate forest in Chile, where $50 \%$ and $8 \%$ of added ${ }^{15} \mathrm{~N}$ is found in the microbial biomass and fine roots, respectively, within one day of its addition (Perakis and Hedin 2001). 
However, since microbial biomass has typically short turnover time (e.g. 12-30 days in Cambisol soils under beech and spruce forests in Germany; Corre et al. 2003, Corre and Lamersdorf 2004) and trees have a longer lifespan, the latter may have a long-term advantage in $\mathrm{N}$ acquisition (Hodge et al. 2000). Another study, conducted in Germany, showed that tree girdling of adult beech trees induced a reduction of C-rich rhizodeposition (Dannenmann et al. 2009); girdling reduced microbial $\mathrm{N}$ turnover rates and stimulated $\mathrm{N}$ uptake by beech trees, illustrating the strong competition between microbial biomass and trees for N. However, there is a lack of studies at ecosystem level on competition for nutrients, other than $\mathrm{N}$, between microbial biomass and trees in temperate forests. Given that in recent decades there is increasing evidence that $\mathrm{P}$ and/or base cations are limiting forest growth in central Europe, it is important to address whether tree-microbial competition exists for these nutrients. A decrease in foliar $\mathrm{P}$ and cation concentrations has been observed in central European forests containing beech or oak (as reported by Duquesnay et al. 2000 for the period between 1969 and 1997 and by Jonard et al. 2009 for the period between 1993 and 2005). Other studies in Germany also showed that P and potassium (K), and not N, are limiting growth in mono-species stands of beech (Ilg et al. 2009; Schmidt et al. 2015), possibly as a result of continuously elevated N deposition (Braun et al. 2010). In particular, our earlier study in Hainich, Germany on unmanaged, old-growth deciduous forests found that nutrient limitation is species-dependent: tree growth of mono-species stands of hornbeam, lime and oak is not limited by N, P and base macronutrients; growth of mono-species beech stands is limited by $\mathrm{P}$ and $\mathrm{K}$; and growth of beech trees mixed with three of these other species is not limited by any of these nutrients (Schmidt et al. 2015).

We conducted our present study in the same old-growth deciduous forests in Hainich, Germany with the following objectives: (1) to determine whether tree species diversity affects nutrient cycling, and (2) whether there is competition for nutrients between microbial biomass and trees. We tested the following hypotheses: (1) tree species diversity enhances nutrient turnover in the litter layer, which will result in larger nutrient availability in the soil and correspondingly in foliar nutrient levels, and (2) as opposed to the mixed-species stands, the mono-species beech stands will have a strong competition between trees and microbial biomass for $\mathrm{P}$ and $\mathrm{K}$. We measured nutrient dynamics during decomposition using in-situ litter bag incubation of four tree species leaf litter (beech, oak, lime and hornbeam). Litter bags were placed in their corresponding mono-species and mixed-species stands and compared this with nutrient levels in the soil, nutrient resorption efficiency by trees prior to leaf senescence and sunlit leaf nutrient levels. 


\subsection{Methods}

\subsubsection{Site description \& stand selection}

This study was conducted in Hainich National Park, which is part of the largest unmanaged deciduous forest ecosystem in central Germany and hosts typical central European tree communities (Mölder et al. 2006). We selected an area of about 25 ha that has Cambisol soils, formed from loess that covers a Triassic limestone. Our site is located near Weberstedt, Thuringia, Germany $\left(51^{\circ} 6^{\prime} 0^{\prime \prime} \mathrm{N}\right.$ $\left.10^{\circ} 30^{\prime} 0^{\prime \prime} \mathrm{E}\right)$. From medieval times up until the 19th century, this forest was used by local farmers for wood and fodder before it was converted into a timber forest with selection cutting (termed in German as Plenterwald) (Fritzlar and Biehl 2006). Starting in 1964, this forest was used solely for military purposes and no other uses were permitted. Since 1997, the Hainich has been a national park with no other uses or forest management permitted except for limited hunting.

Within this forest, we selected stands comprising 4 - 8 trees of beech (Fagus sylvatica), oak (largely Quercus petraea with only few individuals of Quercus robur), hornbeam (Carpinus betulus) and lime (Tilia cordata and Tilia platyphyllus). Stands consisted of one tree species only ('mono-species stands') and of all possible combinations of three of these tree species ('mixed-species stands'), totaling to eight stand types. Each of the stand type was represented by 6 replicate stands (48 stands in total). Stands were selected so that they a) were surrounded only by as few as possible trees of differing species, and b) had trees with a well-developed crown indicating active biomass production.

Stand characteristics and soil parameters were reported in detail by Schmidt et al. (2015). In summary, mono-species stands of beech have larger $(P=0.02)$ diameter at breast height $(\mathrm{dbh}$; mean of $50.6 \mathrm{~cm} \mathrm{dbh}$ ) and were taller (mean of $31.6 \mathrm{~m}$ ) than oak, hornbeam and lime (range of averages were $35.9-45.0 \mathrm{~cm}$ dbh and $24.1-27.1 \mathrm{~m}$ height). However, above-ground net primary production did not differ among tree species (range of averages were $0.70-0.93 \mathrm{~kg} \mathrm{~m}^{-2} \mathrm{yr}^{-1}$ ). Compared to mono-species stands of beech, oak and hornbeam, mono-species stands of lime have higher soil pH (range of averages among mono-species stands: $4.5-5.9)$, total $\mathrm{C}\left(42.7-64.0 \mathrm{MgCha}{ }^{-1}\right)$, effective cation exchange capacity (ECEC; $104-229$ mmolc $\mathrm{kg}-1$ ) and base saturation (58 \% - $96 \%$ ) and lower soil C:N ratio (12.4 $15.2)$ in the top $10-\mathrm{cm}$ depth $(P=0.01-0.06)$ (Schmidt et al. 2015). Soil texture in all replicate plots ranges from silt loam to silty clay loam, which is typical for loess deposited landscape. Hornbeam stands had lower silt (mean of $63.2 \%$ ) and higher clay contents (mean of $35.5 \%$ ) than beech stands (81.0\% silt, $17.6 \%$ clay; $P=0.03-0.04$ ) (Schmidt et al. 2015). These differences in soil texture among stand types were accounted for in our statistical analysis (see Curve-fitting and statistical analysis below). 


\subsubsection{Nutrient contents in sunlit leaves, leaf litterfall and decomposing leaf litter, in-situ decomposition rate, and plant-available nutrients in the soil}

In July 2013, In July 2013, we collected samples of sunlit leaves in all stands with the help of rope-climbing techniques for foliar nutrient analysis. In each mono-species stand, one tree was sampled while in each mixed-species stand, one tree per species was sampled (96 samples in total). Hence, for foliar nutrient concentrations, we used a neighborhood approach (Rothe and Binkley 2001) in the data analysis, measuring the performance of individual trees within the stand. This allows us to compare how a species responds to its immediate surrounding trees, i.e. different neighbors in mono- and mixedspecies stands (Rothe and Binkley 2001). Leaf litterfall for each stand was collected from October to December 2011 and 2012 with one litter trap of $0.5 \mathrm{~m}^{2}$ per stand; the litter trap was placed $1 \mathrm{~m}$ above the ground in order to exclude litter from ground vegetation. We measured the decomposition rate using in-situ litterbag incubation, for which we used the leaf litter collected in 2011. All leaf litter collected from the 6 replicate plots per stand type was pooled for each stand type (in total 8 stand types of pooled leaf litter). Six gram of each stand-type leaf litter ( $2 \mathrm{~g}$ of each species for mixed-species stands) were placed in a $20 \times 20 \mathrm{~cm}$ litter bag with 4-mm mesh size, ensuring that leaf litter would remain within the litter bag while providing access to decomposers and detritivores to leaf litter as in in-situ condition. Four litter bags per stand (with leaf litter composition corresponding to the stand type) were placed in the middle of each stand within the litter layer in November of 2011. One litter bag per stand was harvested on each of these sampling days: March 2012 (after 102 days), July 2012 (after 241 days), December 2012 (after 371 days) and July 2013 (after 605 days). Initial (i.e. prior to in-situ litterbag incubation) leaf litter nutrient concentrations were measured from the pooled samples per stand type in 2011. The initial leaf litter and the leaf litter remaining in the harvested litter bags were immediately dried at $60^{\circ}$ until constant mass (about 3 days), weighed and ground for $C$ and nutrient analysis (see below).

Decomposition rate was determined based on the single-exponential decay model fitted to the amount of leaf litter mass remaining with days of in-situ litterbag incubation (Bärlocher 2005):

$$
\begin{array}{ll}
\operatorname{Mass}_{t}=\operatorname{Mass}_{t 0} e^{-k t} & \text { Equation (1) }
\end{array}
$$

where Mass $_{\text {to }}$ is the initial leaf litter dry mass, Masst is the leaf litter dry mass remaining after $t$ days, and $k$ is the exponential decay coefficient (hereafter, decomposition rate). Since litterbags were incubated in situ over two winter seasons, and therefore represent the actual course of decomposition as opposed to controlled laboratory incubations, we also fitted the exponential model to the amount of leaf litter mass 
remaining with soil temperature sums (measured at a soil depth of $2 \mathrm{~cm}$ ). Each day was then assigned with predicted mass of remaining leaf litter based on its soil temperature sums (Bloemhof and Berendse 1995). We note that the predicted leaf litter mass based on temperature sums deviates slightly from the measured leaf litter mass with days of in-situ incubation because of ongoing decomposition even on days with mean soil temperature at or below zero, in addition to a non-linear relationship between decomposition rates and temperature (Moore 1986).

$\mathrm{C}$ and nutrient concentrations of sunlit leaves, leaf litterfall and decomposing leaf litter were measured using identical methods: total $\mathrm{C}$ and $\mathrm{N}$ concentrations were measured using an elemental analyzer (vario EL cube, Elementar, Hanau, Germany). Total P, K, calcium (Ca) and magnesium (Mg) concentrations were measured, after pressure digestion of samples in concentrated HNO3, using an inductively coupled plasma-atomic emission spectrometer (ICP-AES, iCAP 6300 Duo VIEW ICP Spectrometer, Thermo Fischer Scientific GmbH, Dreieich, Germany).

In each replicate stand, annual plant-available $\mathrm{N}$ was estimated as the sum of net $\mathrm{N}$ mineralization rate in the soil (measured by in-situ buried bag method in five sampling times during the growing season of 2012 and the annual value calculated based on trapezoidal rule) and the atmospheric $\mathrm{N}$ deposition (described in detail by Schmidt et al. 2015). Plant-available $\mathrm{P}$ in the soil during the growing period of 2012 was represented by the average of three sampling days in a year, during which plantavailable $P$ was determined as the sum of resin-exchangeable $P$ and sodium bicarbonate-extractable $P$ (described in detail by Schmidt et al. 2015). As indices of nutrient availability to the plants, soil-

exchangeable $\mathrm{K}, \mathrm{Ca}$ and $\mathrm{Mg}$ were determined using established methods of ECEC measurement (e.g. see Schmidt et al. 2015). Values of soil nutrient availability were then analyzed in relation to parameters of leaf nutrient cycling across 48 stands (see Curve-fitting and statistical analysis).

\subsubsection{Parameters of leaf nutrient cycling}

To test our hypotheses, we used the following parameters of leaf nutrient cycling, calculated based on the measurements described above:

1) Nutrients in annual leaf litterfall were calculated for each replicate stand using the mass of leaf litterfall in 2012 and its nutrient concentration as: 
Annual leaf litter nutrient ( $k g$ nutrient $\mathrm{ha}^{-1}$ year $\left.^{-1}\right)=$

leaf litter nutrient concentration $\frac{\left(\text { mg nutrient } \mathrm{g}^{-1}\right)}{1000} \times$ leaf litter amount $\left(\mathrm{kg} \mathrm{ha}^{-1}\right.$ year $\left.^{-1}\right)$

Equation (2)

2) Nutrients remaining in decomposing leaf litter were calculated on each sampling day as:

Nutrient retained in leaf litter ( $m$ g element per $g$ of initial leaf litter) $=$

element concentration on a sampling day $x \frac{\text { litter mass remaining }}{\text { initial leaf litter mass }} \quad$ Equation (3)

3) Critical $C: N$ and $C: P$ ratios (i.e. defined as the $C: N$ and $C: P$ ratios below which net $N$ or $P$ mineralization occurs) of the decomposing leaf litter were based on the sampling period with the highest $\mathrm{N}$ or $\mathrm{P}$ remaining in the leaf litter prior to the sampling period when net $\mathrm{N}$ or $\mathrm{P}$ mineralization was detected (Berg and McClaugherty 2003). In cases where there were always net $\mathrm{N}, \mathrm{P}$ or $\mathrm{K}$ mineralization, we took the $\mathrm{C}: \mathrm{N}, \mathrm{C}: \mathrm{P}$ and $\mathrm{C}: \mathrm{K}$ ratios of the initial leaf litter as the critical values.

4) Nutrient change during leaf litter decomposition was calculated as the difference between the total nutrient content in the initial leaf litter and the nutrient remaining in leaf litter after approximately one year (hereafter, annual net nutrient change). Positive values of annual net nutrient change indicate net mineralization after one year while negative values indicate net immobilization of nutrients after one year.

5) Nutrient resorption efficiency by trees was calculated following Kobe et al. (2005):

Resorption efficiency $=\frac{\text { foliar nutrient concentration }- \text { leaf litter nutrient concentration }}{\text { foliar nutrient concentration }} \times 100$

Equation (4)

For foliar nutrient concentrations in mixed-species stands, the proportions of the different species in the leaf litterfall of 2011 were used to weight the nutrient concentrations of the contributing species.

6) Finally, we used the critical foliar N, P and K concentrations for beech and oak (van den Burg 1985; 1990; as cited by Mellert and Göttlein 2012) as the basis to assess the tree species' nutritional status. 


\subsubsection{Curve-fitting and statistical analysis}

The relationships of annual net nutrient change in decomposing leaf litter with leaf litter quality (i.e. C:nutrient ratios), plant-available nutrients in the soil, and nutrient resorption efficiencies by trees were assessed using the best curve fittings. For the relationship of annual net nutrient change with leaf litter quality, the boundary condition is that leaf litter C:nutrient ratios cannot reach or go below zero, and the best curve-fit was a $\log _{10}$ function: $y=a-b \log _{10} x$. For the relationship of annual net nutrient change with plant-available nutrients in the soil, the boundary criterion is that soil nutrient levels cannot go below zero, and the best curve-fit was an exponential function: $y=a e^{b x}$. For the relationship of annual net nutrient change or soil nutrient availability with nutrient resorption efficiencies by trees, the boundary condition is that the maximum value of resorption efficiency is $100 \%$ as the trees cannot resorb more than what is present in the leaves. For this, the best curve-fit was a Michaelis-Menten function: $y=(-x+a) b /(-x+a+b)$ (Aitken et al. 2009). Since linear regression is inappropriate to evaluate these non-linear functions (Spiess and Neumeyer 2010), we used a Spearman rank correlation between fitted and observed values to assess the goodness of curve-fittings.

For statistical analysis of differences among stand types, each parameter was first tested for normality using the Shapiro-Wilk test and for homoscedasticity using the non-constant variance score test (Fox and Weisberg 2011). We conducted either an analysis of covariance (ANCOVA) for parameters that showed normal distribution and homogeneity of variance or a generalized linear model (GLM) for parameters that did not meet normal distribution and variance homogeneity criteria even after transformation. This was followed by Tukey HSD test (Hothorn et al. 2008) for testing differences among stand types in nutrients in leaf litterfall, decomposition rates, annual net nutrient change, plant-available nutrients in the soil and foliar nutrient concentrations. Due to the naturally occurring variation in soil texture among the replicate stands (see Site description \& stand selection above), we used clay content as a covariate in ANCOVA and GLM (e.g. Yamashita et al. 2008). Thus, all statistical differences among stand types are based on the adjusted means with this covariate factor. For assessing the relationships of decomposition rates with leaf litter quality, soil biochemical properties and plant-available nutrients in the soil, we also incorporate clay content as a control variable and used partial Pearson correlation test (Kim 2012). For all tests, the level of statistical significance is set at $P \leq 0.05$, except for a few specified parameters that showed marginal significance at $P<0.10$. We considered this marginal significant effect because our experimental design has encompassed the inherent spatial variation in our unmanaged forest ecosystem. Statistical analyses as well as curve-fittings were conducted using R version 3.0.1 ( $R$ Development Core Team 2013). 


\subsection{Results}

\subsubsection{Nutrient concentrations in leaf litter, soil and sunlit leaves of mono-species stands}

Leaf litter N, P and K concentrations were higher in lime and hornbeam stands than in beech and/or oak stands $(P \leq 0.01)$ (Table 1$)$. Lime and hornbeam stands had lower leaf litter $\mathrm{C}: \mathrm{N}$ and $\mathrm{C}: \mathrm{P}$ ratios than beech and oak stands $(P \leq 0.01)$ (Table 2.1$)$. The leaf litter $C: K$ ratios displayed collinearity with clay contents and thus differences in C:K ratios among species could not be statistically differentiated from the effect of clay content.

Plant-available $\mathrm{N}$ and exchangeable $\mathrm{K}$ in the soil did not differ among mono-species stands $(P=$ 0.79 for $N$ and $P=0.18$ for $\mathrm{K}$ ), whereas plant-available $\mathrm{P}$ in hornbeam stands was higher than in beech stands $(P=0.05)$ (Table 2.1). The soil $C_{\text {total }}: N_{\text {total }}, C_{\text {total }}: P_{\text {total }}$ and $C_{\text {total }}: K_{\text {exchangeable }}$ ratios in hornbeam and lime stands were lower than in beech and/or oak stands $(P<0.01)$ (Table 2.1).

Foliar $\mathrm{N}$ and $\mathrm{P}$ concentrations were higher $(P<0.01)$ and foliar $\mathrm{C}: \mathrm{N}$ and $\mathrm{C}: \mathrm{P}$ ratios were lower $(P<$ 0.01) in lime stands than in all other mono-species stands (Table 2.1). Also, the foliar C:K ratios in lime stands were lower than in hornbeam stands $(P=0.03)$ (Table 2.1). The species differences in foliar $\mathrm{K}$ concentrations could not be statistically distinguished from the effect of clay content due to their collinearity.

\subsubsection{Nutrient contents in leaf litterfall}

Among mono-species stands, hornbeam had higher annual leaf litter $\mathrm{N}$ content than all other species' stands $(P=0.02)$, higher annual leaf litter $P$ content than beech and oak stands $(P<0.01)$, higher annual leaf litter $\mathrm{K}$ content than beech and lime stands $(P<0.01)$, higher annual leaf litter Ca content than oak stands $(P=0.01)$ and higher annual leaf litter $\mathrm{Mg}$ content than lime stands $(P=0.01)$ (Table 2.2). Among mixed-species stands, annual leaf litter $\mathrm{Ca}$ and $\mathrm{Mg}$ contents were higher when oak and lime were mixed with hornbeam instead of with beech $(P=0.01)$.

Comparing annual leaf litter nutrient contents across mono- and mixed-species stands, hornbeam showed higher annual leaf litter N, K, Ca and Mg contents than the mixed stands of beechoak-lime $(P<0.01-0.02)$ and higher annual leaf litter $P$ content than the mixed stands of beech-oakhornbeam $(P<0.01)$. Additionally, beech showed lower annual leaf litter $P$ content than the mixed stands of oak-hornbeam-lime and lower annual leaf litter K content than the mixed stands containing both hornbeam and lime $(P<0.01)$ (Table 2.2). 


\section{Table 2.1}

Nutrient concentrations and carbon:nutrient ratios in leaf litter (measured in 2012), soil (measured in the top 0.1-m depth in 2012) and sunlit leaves (measured in 2013) in the mono-species stands.

\begin{tabular}{lllllll} 
Leaf litter & & & & & \\
& $\mathrm{N}$ & $\mathrm{P}$ & $\mathrm{K}$ & $\mathrm{C}: \mathrm{N}$ & $\mathrm{C}: \mathrm{P}$ & $\mathrm{C}: \mathrm{K}^{*}$ \\
& $\mathrm{mg} \mathrm{g}^{-1}$ & $\mathrm{mg} \mathrm{g}^{-1}$ & $\mathrm{mg} \mathrm{g}^{-1}$ & ratio & ratio & ratio \\
& & & & & & \\
beech & $7.7 \pm 0.3 \mathrm{bc}$ & $0.2 \pm 0.0 \mathrm{~b}$ & $3.8 \pm 0.4 \mathrm{~b}$ & $60.5 \pm 2.2 \mathrm{a}$ & $2109 \pm 139 \mathrm{a}$ & $127.9 \pm 11.3$ \\
oak & $7.6 \pm 0.5 \mathrm{c}$ & $0.3 \pm 0.0 \mathrm{~b}$ & $6.2 \pm 0.5 \mathrm{a}$ & $61.6 \pm 3.7 \mathrm{a}$ & $1519 \pm 87 \mathrm{~b}$ & $76.7 \pm 5.9$ \\
hornbeam & $9.3 \pm 0.3 \mathrm{ab}$ & $0.5 \pm 0.0 \mathrm{a}$ & $6.3 \pm 0.2 \mathrm{a}$ & $48.7 \pm 1.6 \mathrm{~b}$ & $997 \pm 76 \mathrm{c}$ & $71.7 \pm 2.3$ \\
lime & $10.2 \pm 0.4 \mathrm{a}$ & $0.5 \pm 0.0 \mathrm{a}$ & $7.0 \pm 0.5 \mathrm{a}$ & $45.2 \pm 1.4 \mathrm{~b}$ & $946 \pm 60 \mathrm{c}$ & $67.3 \pm 5.4$ \\
\hline
\end{tabular}

\begin{tabular}{|c|c|c|c|c|c|c|}
\hline & Plant-available & Plant-available & Exchangeable $\mathrm{K}$ & $\mathrm{C}: \mathrm{N}^{* *}$ & $C: P$ & $\mathrm{C}: \mathrm{K}$ \\
\hline & $\mathrm{N}^{* *}$ & $P^{* *}$ & $\mathrm{mmol}_{\mathrm{c}} \mathrm{kg}^{-1}$ & ratio & ratio & ratio \\
\hline & $\mathrm{kg} \mathrm{ha}^{-1}$ year-1 $^{-1}$ & $\mathrm{~kg} \mathrm{ha}^{-1}$ & & & & \\
\hline beech & $141.4 \pm 29.9 \mathrm{a}$ & $49.2 \pm 3.3 \mathrm{~b}$ & $3.3 \pm 0.4 \mathrm{a}$ & $15.2 \pm 0.3 a b$ & $118 \pm 6 a$ & $6.0 \pm 0.5 \mathrm{a}$ \\
\hline oak & $92.2 \pm 44.9 \mathrm{a}$ & $62.1 \pm 4.2 \mathrm{ab}$ & $4.0 \pm 0.5 \mathrm{a}$ & $16.1 \pm 0.5 \mathrm{a}$ & $105 \pm 6 a b$ & $5.1 \pm 0.4 \mathrm{a}$ \\
\hline hornbeam & $94.5 \pm 33.9 \mathrm{a}$ & $82.4 \pm 12.1 \mathrm{a}$ & $6.5 \pm 0.8 a$ & $14.0 \pm 0.5 \mathrm{bc}$ & $89 \pm 8$ bc & $3.6 \pm 0.6 b$ \\
\hline lime & $116.5 \pm 26.6 \mathrm{a}$ & $60.4 \pm 3.2 \mathrm{ab}$ & $5.0 \pm 0.3 a$ & $12.4 \pm 0.3 \mathrm{c}$ & $73 \pm 4 c$ & $2.9 \pm 0.2 b$ \\
\hline
\end{tabular}

\section{Sunlit leaves}

\begin{tabular}{|c|c|c|c|c|c|c|}
\hline & $\begin{array}{l}\mathrm{N} \\
\mathrm{mg} \mathrm{g}^{-1}\end{array}$ & $\begin{array}{l}P \\
\mathrm{mg} \mathrm{g}^{-1}\end{array}$ & $\begin{array}{l}\mathrm{K}^{*} \\
\mathrm{mg} \mathrm{g}^{-1}\end{array}$ & $\begin{array}{l}\text { C:N } \\
\text { ratio }\end{array}$ & $\begin{array}{l}\mathrm{C}: \mathrm{P} \\
\text { ratio }\end{array}$ & $\begin{array}{l}\text { C:K } \\
\text { Ratio }\end{array}$ \\
\hline beech & $20.9 \pm 0.6 b$ & $0.9 \pm 0.1 b$ & $9.0 \pm 0.8$ & $23.2 \pm 0.8 \mathrm{a}$ & $545 \pm 36$ a & $55.5 \pm 4.8 \mathrm{ab}$ \\
\hline oak & $22.3 \pm 0.7 \mathrm{~b}$ & $1.1 \pm 0.1 \mathrm{~b}$ & $8.9 \pm 0.5$ & $21.8 \pm 0.6 \mathrm{a}$ & $479 \pm 58 a$ & $55.2 \pm 3.7 \mathrm{ab}$ \\
\hline hornbeam & $20.5 \pm 0.5 b$ & $1.1 \pm 0.0 \mathrm{~b}$ & $7.7 \pm 0.5$ & $22.8 \pm 0.5 \mathrm{a}$ & $424 \pm 9 a$ & $61.6 \pm 3.5 b$ \\
\hline lime & $26.1 \pm 0.7 \mathrm{a}$ & $1.7 \pm 0.1 \mathrm{a}$ & $13.1 \pm 1.8$ & $18.4 \pm 0.6 \mathrm{~b}$ & $290 \pm 15 b$ & $40.8 \pm 6.2 \mathrm{a}$ \\
\hline
\end{tabular}

Means (SE, $n=6$ replicate stands) in each column with different letter indicate significant differences among mono-species stands (ANCOVA with Tukey HSD test at $P \leq 0.05$ ).

* Collinearity, i.e. effect of different species composition cannot be statistically distinguished from that of clay content effect

** values reported by Schmidt et al. (2015) 


\subsubsection{Leaf litter decomposition rates $(k)$ and nutrients remaining in decomposing leaf litter}

While the leaf litter mass remaining after 605 days of in-situ incubation was close to zero for hornbeam and lime leaf litters, considerable amounts still remained for beech and oak leaf litters (Fig. 2.1). Decomposition rates across all stands ranged from $0.2 \times 10^{-3} \mathrm{~d}^{-1}$ to $6.3 \times 10^{-3} \mathrm{~d}^{-1}$ with a mean of 3.3 ( $\pm 0.3 \mathrm{SE}) \times 10-3 \mathrm{~d}^{-1}$. Among mono-species stands, decomposition rates were lowest for beech leaf litter in its stand, intermediate for oak leaf litter in its stand, and highest for lime and hornbeam leaf litters in their respective stands $(P<0.01)$ (Fig. 2.1). Among mixed-species stands, the oak-hornbeam-lime leaf litter decomposed faster than all mixed-species compositions containing beech in their respective stands. Between mono- and mixed-species stands, beech leaf litter in its mono-species stand decomposed slower than any of the mixed-species compositions containing beech $(P<0.01)$, whereas oak leaf litter in its mono-species stand decomposed slower than oak mixed with lime leaf litter in its respective stand $(P<0.01)$. On the other hand, hornbeam and lime leaf litters in their mono-species stands decomposed faster than any of their mixed-species compositions containing beech $(P \leq 0.01)$ (Fig. 2.1).

In several cases, decomposing leaf litter showed higher nutrient amount as compared to the initial nutrient content in leaf litter (Fig. 2.2). This was especially clear for beech and oak leaf litters, which showed the highest $\mathrm{N}$ content in decomposing leaf litter at 241 days (oak) and 371 days (beech). Furthermore, the $\mathrm{P}$ content in decomposing beech leaf litter peaked at 371 days, whereas oak and mixed-species leaf litters containing both beech and oak reached the highest P contents in decomposing litter at 241 days. Ca and Mg contents in decomposing oak leaf litter were highest at 102 days (Fig. 2.2).

Partial Pearson correlations showed $k$ to be strongly influenced by leaf litter quality, soil biochemical properties and only selectively affected by plant-available nutrients in the soil (Appendix 2.I). Positive correlations with $k$ were detected for leaf litter $\mathrm{N}, \mathrm{P}, \mathrm{K}, \mathrm{Ca}$ and $\mathrm{Mg}$, soil $\mathrm{pH}$, and exchangeable $\mathrm{Ca}$ and $\mathrm{Mg}$ in the soil. Decomposition rates were negatively correlated with $\mathrm{C}_{\text {total }}: \mathrm{N}_{\text {total }}$ and $\mathrm{N}_{\text {total }}: \mathrm{P}_{\text {total }}$ ratios of leaf litter and soil (Appendix 2.I). 


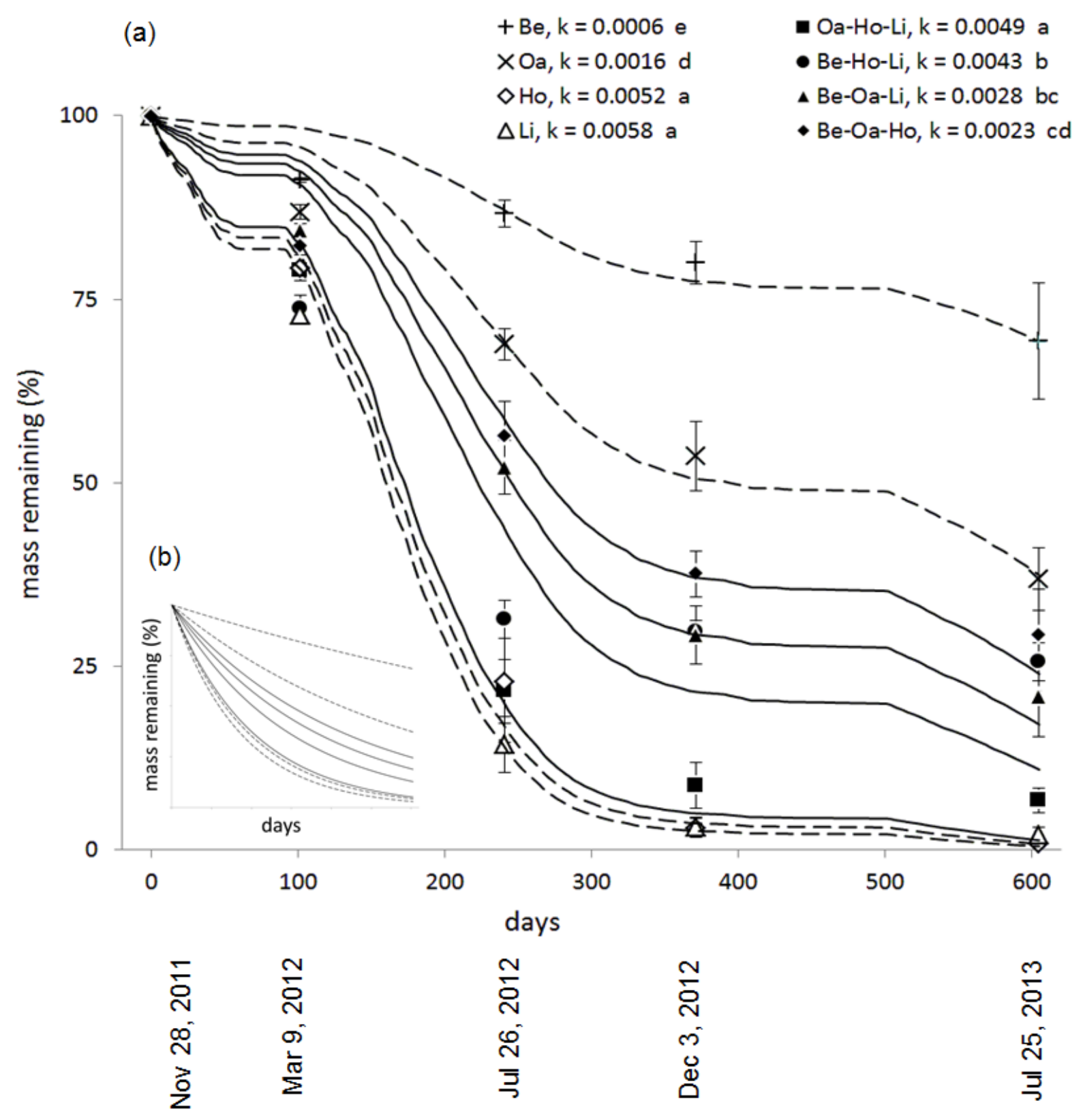

Fig. 2.1

Mass remaining (dry mass of remaining leaf litter on a sampling day/initial dry mass of leaf litter * 100) with (a) the sum of air temperature above $0{ }^{\circ} \mathrm{C}$ corresponding to the days of in-situ incubation, and (b) days of in-situ incubation of litterbags. Dashed line represents mono-species leaf litter of beech $(\mathrm{Be})$, oak $(\mathrm{Oa})$, hornbeam $(\mathrm{Ho})$ and lime stands $(\mathrm{Li})$; solid line represents mixed-species stands of three of these species. Decomposition rates are calculated using the single-exponential decay model and represented by the coefficient $k\left(\mathrm{~d}^{-1}\right)$ (Bärlocher 2005). Different letters indicate significant differences in decomposition rates, $k$, among stands (ANCOVA with Tukey HSD test at $P<0.01$ ). 

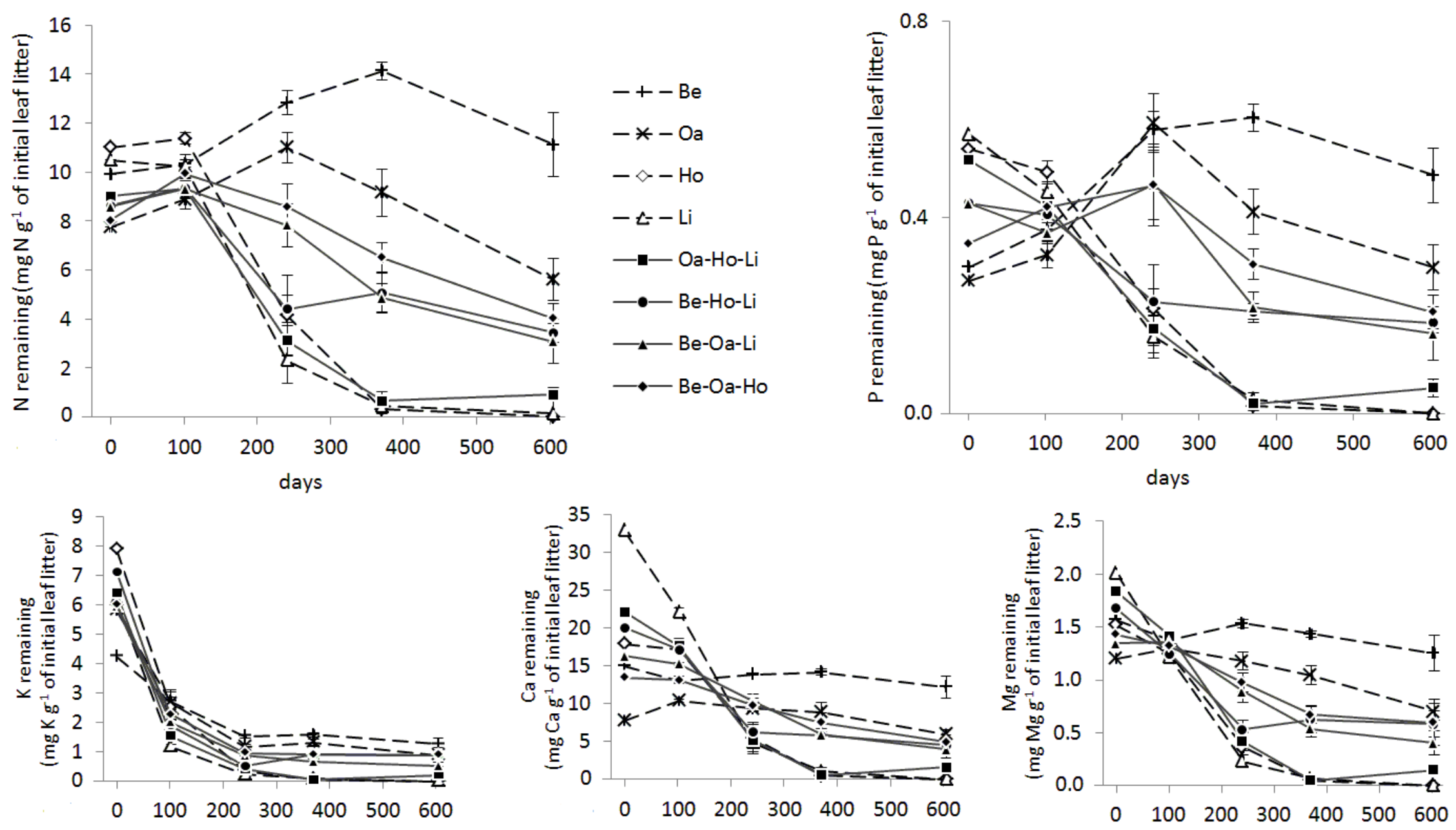

Fig. 2.2

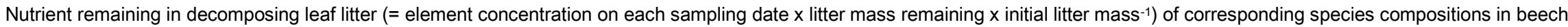
$(\mathrm{Be})$, oak (Oa), hornbeam ( $\mathrm{Ho})$, lime ( $\mathrm{Li})$ and mixed-species stands of three of these species during 605 days of in-situ litter bag incubation. Dashed line represents mono-species stands and solid line represents mixed-species stands. 


\subsubsection{Annual net nutrient change in decomposing leaf litter}

Among mono-species stands, annual net $\mathrm{N}$ change in decomposing leaf litter declined in the following order: hornbeam $=$ lime $>$ oak $>$ beech $(P<0.01)$ (Table 2.3$)$. Annual net $\mathrm{K}$ change followed this order: hornbeam $>$ lime $>$ oak $>$ beech $(P<0.01)$. Annual net $\mathrm{Mg}$ change showed this order: lime $>$ hornbeam $>$ oak $=$ beech $(P<0.01)$. Mono-species beech stands showed net immobilization of $\mathrm{N}$ and $\mathrm{P}$ and mono-species oak stands showed net immobilization of N, P and $\mathrm{Ca}$, whereas none of the mixedspecies stands showed net immobilization of any of the nutrients (i.e. no negative values for mixedspecies stands; Table 2.3). Among mixed-species stands, annual net $\mathrm{N}$ and $\mathrm{Mg}$ change in decomposing leaf litters containing oak with both hornbeam and lime was higher than any of the mixed leaf litters containing beech, and the lowest was in leaf litter containing both beech and oak with hornbeam $(P<$ 0.01) (Table 2.3). Decomposing leaf litter of mixed species containing both hornbeam and lime had higher annual net $\mathrm{K}$ change than mixed species containing both beech and oak $(P<0.01)$. Between mono- and mixed-species stands, mono-species stands of hornbeam and lime generally showed higher net mineralization of $\mathrm{N}, \mathrm{K}$ and $\mathrm{Mg}$ than their mixed-species stands with both beech and oak $(P<0.01)$ (Table 2.3). Conversely, mono-species stands of beech and oak displayed lower net mineralization of $\mathrm{N}, \mathrm{K}$ and $\mathrm{Mg}$ compared to their mixed-species stands containing both hornbeam and lime $(P<0.01)$. For annual net $\mathrm{P}$ and $\mathrm{Ca}$ change, the effects of species composition and clay content could not be statistically distinguished (due to collinearity) and thus differences among stands could not be assessed (Table 2.3).

Across mono- and mixed-species stands, annual net N, P and $\mathrm{K}$ change in decomposing leaf litter decreased with increasing $C: N, C: P$ and $C: K$ ratios of the initial leaf litters (first row in Fig. 2.3). Critical C: $\mathrm{N}$ ratios (below which net nutrient mineralization occurred) for the stands in this deciduous forest ranged from 27 to 43 and critical C:P ratios ranged from 527 to 1003 . No net $\mathrm{K}$ immobilization occurred in any of the litter bags (i.e. no negative values for annual net $\mathrm{K}$ change in Table 2.3), suggesting that critical C:K ratios were lower than the C:K ratios (i.e. 65 - 110) in the initial leaf litter we measured. We did not detect a significant relationship between annual net $\mathrm{N}$ change in decomposing leaf litter and plant-available $\mathrm{N}$ in the soil, but plant-available $\mathrm{P}$ and exchangeable $\mathrm{K}$ in the soil increased with annual net $\mathrm{P}$ and $\mathrm{K}$ change in decomposing leaf litter (second row in Fig. 2.3). N, $\mathrm{P}$ and $\mathrm{K}$ resorption efficiencies by trees were highest when annual net N, P and $\mathrm{K}$ changes in decomposing litter (third row in Fig. 2.3) as well as plant-available $\mathrm{P}$ and exchangeable $\mathrm{K}$ in the soil were lowest (fourth row in Fig. 2.3). Based on the Michaelis-Menten function fitted across all stands, the optimum resorption efficiencies by trees were $64 \%$ for $\mathrm{N}, 76 \%$ for $\mathrm{P}$ and $60 \%$ for $\mathrm{K}$ (third row in Fig. 2.3). 
Table 2.2

Annual leaf litter fall N, P, K, Ca and Mg in mono-species and mixed species stands, measured in 2012.

\begin{tabular}{|c|c|c|c|c|c|c|c|c|}
\hline \multicolumn{9}{|c|}{ Nutrients in leaf litter fall ${ }^{*}\left(\mathrm{~kg}_{\text {nutrient }} \mathrm{ha}^{-1}\right.$ year $\left.^{1}\right)$} \\
\hline Nutrient & Beech $(\mathrm{Be})$ & Oak (Oa) & Hornbeam (Ho) & Lime (Li) & Oa-Ho-Li & $\mathrm{Be}-\mathrm{Ho}-\mathrm{Li}$ & $\mathrm{Be}-\mathrm{Oa}-\mathrm{Li}$ & $\mathrm{Be}-\mathrm{Oa}-\mathrm{Ho}$ \\
\hline $\mathrm{N}$ & $25.0 \pm 1.3 b$ & $24.4 \pm 2.4 \mathrm{~b}$ & $35.6 \pm 2.7 \mathrm{a}$ & $25.3 \pm 1.4 \mathrm{~b}$ & $31.3 \pm 2.0 \mathrm{ab}$ & $27.5 \pm 1.1 \mathrm{ab}$ & $24.2 \pm 1.4 \mathrm{~b}$ & $30.2 \pm 3.8 a b$ \\
\hline$P$ & $0.7 \pm 0.0 \mathrm{c}$ & $1.0 \pm 0.1 \mathrm{bc}$ & $1.8 \pm 0.2 \mathrm{a}$ & $1.2 \pm 0.1 \mathrm{ab}$ & $1.6 \pm 0.1 \mathrm{ab}$ & $1.1 \pm 0.1 \mathrm{abc}$ & $1.1 \pm 0.2 \mathrm{abc}$ & $1.1 \pm 0.2 \mathrm{bc}$ \\
\hline K & $12.3 \pm 1.3 \mathrm{c}$ & $19.7 \pm 2.1 \mathrm{ab}$ & $24.1 \pm 1.7$ a & $17.3 \pm 1.2 \mathrm{bc}$ & $21.1 \pm 1.0 \mathrm{ab}$ & $20.3 \pm 1.5 a b$ & $15.7 \pm 1.7 \mathrm{bc}$ & $18.5 \pm 1.2 \mathrm{abc}$ \\
\hline $\mathrm{Ca}$ & $39.0 \pm 1.4 \mathrm{ab}$ & $35.6 \pm 2.7 \mathrm{~b}$ & $61.2 \pm 3.7$ a & $51.5 \pm 3.8 \mathrm{ab}$ & $59.6 \pm 5.8$ a & $51.7 \pm 4.6 \mathrm{ab}$ & $38.5 \pm 3.4 \mathrm{~b}$ & $44.9 \pm 4.4 \mathrm{ab}$ \\
\hline $\mathrm{Mg}$ & $4.3 \pm 0.1 \mathrm{abc}$ & $4.5 \pm 0.3 \mathrm{abc}$ & $5.8 \pm 0.4 a$ & $4.2 \pm 0.2 \mathrm{bc}$ & $5.6 \pm 0.5 a b$ & $4.7 \pm 0.4 a b c$ & $3.5 \pm 0.2 \mathrm{c}$ & $4.8 \pm 0.2 \mathrm{abc}$ \\
\hline
\end{tabular}

Means (SE, $\mathrm{n}=6$ replicate stands) in each row with different letter indicate significant differences among species compositions (ANCOVA with Tukey HSD test at $P \leq 0.02$ ).

* Nutrients in leaf litter fall $=$ nutrient concentration $x$ rate of leaf litterfall

Table 2.3

Annual net nutrient change in decomposing leaf litter in mono- and mixed-species stands, measured from November $2012\left(t_{0}\right)$ to December $2013\left(t_{1}\right)$.

Nutrient change ${ }^{*}$ (mg nutrient $g^{-1}$ of initial leaf litter year ${ }^{1}$ )

\begin{tabular}{|c|c|c|c|c|c|c|c|c|}
\hline Nutrient & Beech $(\mathrm{Be})$ & Oak (Oa) & Hornbeam $(\mathrm{Ho})$ & Lime (Li) & Oa-Ho-Li & $\mathrm{Be}-\mathrm{Ho}-\mathrm{Li}$ & $\mathrm{Be}-\mathrm{Oa}-\mathrm{Li}$ & $\mathrm{Be}-\mathrm{Oa}-\mathrm{Ho}$ \\
\hline $\mathrm{N}$ & $-4.2 \pm 0.4 f$ & $-1.4 \pm 1.0 \mathrm{e}$ & $10.7 \pm 0.2 \mathrm{a}$ & $10.0 \pm 0.2 a b$ & $8.3 \pm 0.3 b$ & $3.6 \pm 0.8 \mathrm{c}$ & $3.7 \pm 0.6 \mathrm{c}$ & $1.5 \pm 0.6 \mathrm{~d}$ \\
\hline$P^{* *}$ & $-0.3 \pm 0.0$ & $-0.1 \pm 0.0$ & $0.5 \pm 0.0$ & $0.5 \pm 0.0$ & $0.5 \pm 0.0$ & $0.2 \pm 0.0$ & $0.2 \pm 0.0$ & $0.0 \pm 0.0$ \\
\hline K & $2.7 \pm 0.1 \mathrm{e}$ & $4.5 \pm 0.1 \mathrm{~d}$ & $7.8 \pm 0.0 \mathrm{a}$ & $6.1 \pm 0.0 \mathrm{~b}$ & $6.3 \pm 0.0 \mathrm{~b}$ & $6.2 \pm 0.2 \mathrm{~b}$ & $5.3 \pm 0.1 \mathrm{c}$ & $5.1 \pm 0.1 \mathrm{c}$ \\
\hline $\mathrm{Ca}^{* *}$ & $0.8 \pm 0.5$ & $-1.1 \pm 1.2$ & $17.4 \pm 0.3$ & $31.9 \pm 0.5$ & $21.6 \pm 0.2$ & $14.3 \pm 0.4$ & $10.4 \pm 0.8$ & $6.0 \pm 1.2$ \\
\hline $\mathrm{Mg}$ & $0.1 \pm 0.0 \mathrm{e}$ & $0.2 \pm 0.1 \mathrm{e}$ & $1.5 \pm 0.0 \mathrm{~b}$ & $1.9 \pm 0.0 \mathrm{a}$ & $1.8 \pm 0.0 \mathrm{a}$ & $1.1 \pm 0.1 \mathrm{c}$ & $0.8 \pm 0.1 \mathrm{~cd}$ & $0.8 \pm 0.1 \mathrm{~d}$ \\
\hline
\end{tabular}

Means (SE, $\mathrm{n}=6$ replicate stands) in each row with different letter indicate significant differences among species compositions (ANCOVA with Tukey HSD test at $P<0.01$ ).

${ }^{*}$ Nutrient change $=t_{0}-t_{;} ; t_{0}=$ initial nutrient concentration; $t_{1}=$ nutrient concentration at 371 days of incubation $\mathrm{x}$ remaining leaf litter mass $\mathrm{x}$ initial leaf litter mass ${ }^{-1}$

** Collinearity, i.e. effect of different species composition cannot be statistically distinguished from that of soil texture effect 
Fig. 2.3
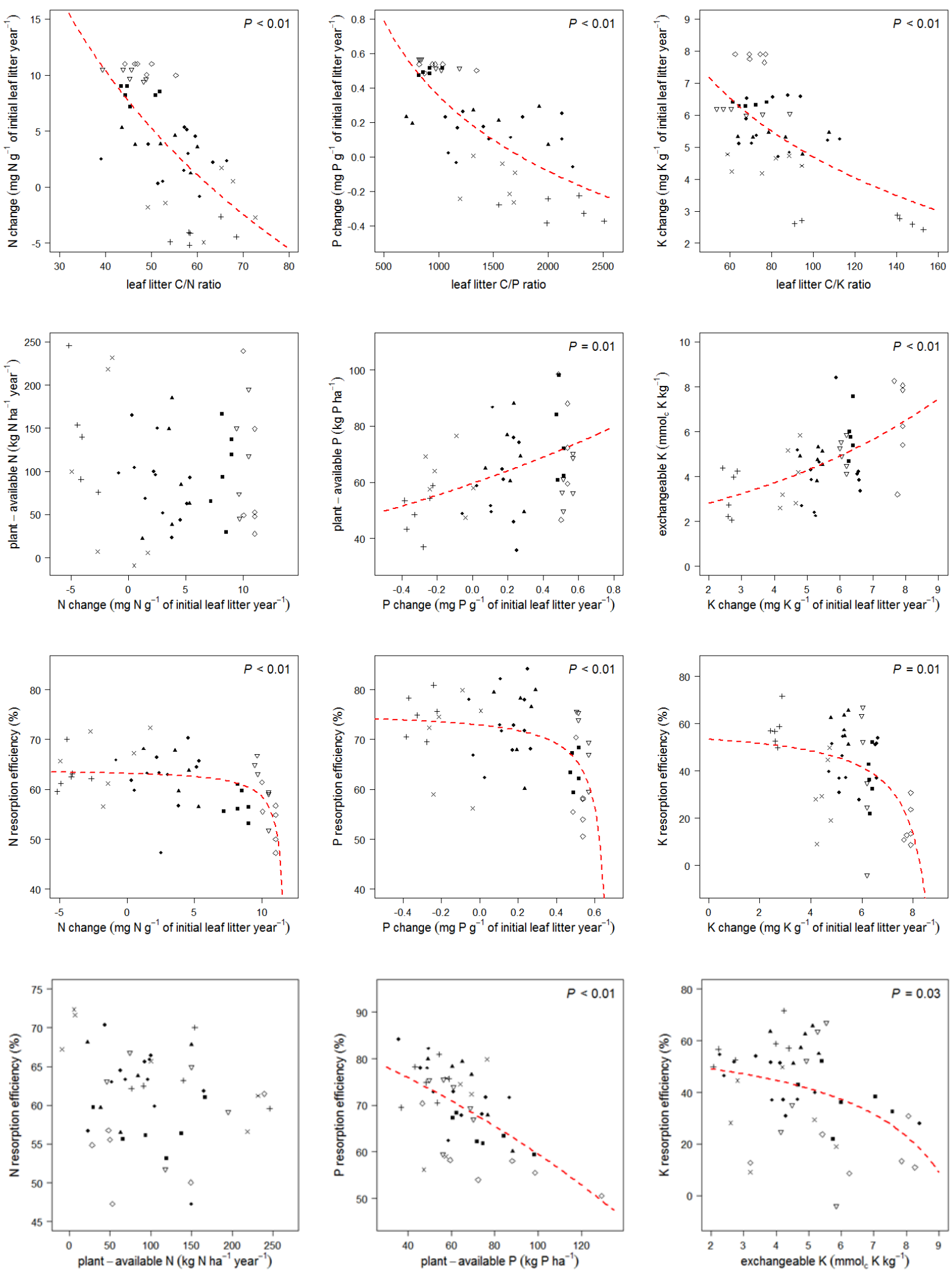
(Caption to Fig. 2.3) Best curve fits (indicated by $P$ values in each panel) for the relationships of net annual changes in nitrogen (N; first column), phosphorus ( $\mathrm{P}$; middle column) and potassium (K; right column) of decomposing litter with leaf litter quality (first row; a $\log _{10}$ function), plant-available nutrients (second row; an exponential function) and nutrient resorption efficiency by trees (third row; a Michaelis-Menten function) as well as plant-available nutrients with nutrient resorption efficiency (fourth row; a Michaelis-Menten function). Net annual nutrient change $=t_{0}-t_{i} ; t_{0}=$ initial nutrient concentration; $t_{1}=$ nutrient concentration at 371 days of incubation $\mathrm{x}$ remaining leaf litter mass $x$ initial leaf litter mass ${ }^{-1}$. Resorption efficiency by trees $=$ (sunlit leaf nutrient concentration in $2013-$ leaf litter nutrient concentration in 2012) / sunlit leaf nutrient concentration in 2013 x 100. For foliar nutrient concentrations in mixedspecies stands, the proportions of leaf litter compositions in 2011 were used to calculate the weighted average for each replicate plot. $\mathrm{n}=46-48 .(+)=$ beech $(\mathrm{Be}),(\times)=$ oak $(\mathrm{Oa}),(\diamond)=$ hornbeam $(\mathrm{Ho}),(\nabla)=\operatorname{lime}(\mathrm{Li}),(\boldsymbol{\square})=\mathrm{Oa}-\mathrm{Ho}-\mathrm{Li},(\bullet)=\mathrm{Be}-\mathrm{Ho}-\mathrm{Li},(\boldsymbol{\bullet}) \mathrm{Be}-$ Oa-Li, $(\bullet)=$ Be-Oa-Ho.

\subsubsection{Sunlit leaf nutrient status}

Based on foliar nutrient ranges from van den Burg (1985, 1990, as cited by Mellert and Göttlein 2012), foliar $\mathrm{N}$ concentrations in $71 \%$ of beech trees and $96 \%$ of oak trees were in the normal range whereas $21 \%$ of beech trees displayed $\mathrm{N}$ concentrations on the surplus level (Appendix 2.II). In contrast, $67 \%$ of beech trees and $79 \%$ of oak trees had foliar P concentrations on the deficient level while only $33 \%$ of beech trees and $21 \%$ of oak trees had foliar $\mathrm{P}$ concentrations in the normal range. Foliar $\mathrm{K}$ concentrations in $63 \%$ of beech trees showed on the surplus level (and one-third of beech trees in the normal range) whereas $61 \%$ of oak trees displayed in the normal range (and one-third of oak trees displayed on the surplus level) (Appendix 2.II).

Foliar $\mathrm{N}$ concentrations did not differ between mono- and mixed-species stands of beech $(n=6$, $P=0.31)$ or oak $(n=6, P=0.64)$. However, beech trees had higher foliar $P$ concentrations in mixed stands with lime compared to mono-species beech stands $(n=6, P=0.04)$, whereas oak trees showed lower foliar $\mathrm{K}$ concentrations in mixed stands with beech and lime compared to mono-species oak stands $(\mathrm{n}=6, P=0.02)$.

\subsection{Discussion}

\subsubsection{Nutrient content in leaf litterfall, decomposition rate $(k)$, and foliar nutrient in comparison with other temperate forests}

$\mathrm{N}$ content in leaf litterfall at our site (Table 2.2) was comparable with other temperate forests with $26.2 \mathrm{~kg} \mathrm{~N} \mathrm{ha}^{-1}$ year $^{-1}$ (hardwood forest in Quebec, Canada; Duchesne et al. 2001), $29.9 \mathrm{~kg} \mathrm{~N} \mathrm{ha}{ }^{-1}$ year $^{-1}$ (hardwood forest in New Hampshire, USA; Gosz et al. 1972) and $33.3 \mathrm{~kg} \mathrm{~N}^{-1}$ year $^{-1}$ (mixed beech 
stands in Hainich, Germany; Guckland et al. 2009). However, an oak-hickory forest in Illinois, USA had a higher $\mathrm{N}$ content (49.2 $\mathrm{kg} \mathrm{N} \mathrm{ha}^{-1}$ year $^{-1}$ ), which we attribute to the high leaf litterfall (Peterson and Rolfe 1982).

P content in leaf litterfall at our site (Table 2.2) was lower than those reported for Quebec and New Hampshire hardwood forests (1.9 and $1.8 \mathrm{~kg} \mathrm{P} \mathrm{ha}^{-1}$ year $^{-1}$, respectively; Gosz et al. 1972; Duchesne et al. 2001) and much lower than the Illinois oak-hickory site $\left(6.8 \mathrm{~kg} \mathrm{P} \mathrm{ha}^{-1} \mathrm{year}^{-1}\right.$; Peterson and Rolfe 1982). Leaf litter $P$ content of beech stands at Hainich, Germany (1.4 kg P ha ${ }^{-1} y^{-1}{ }^{-1}$; calculated from Guckland et al. 2009) is as low as the leaf litter P content at our mono-species beech stands (Table 2.2). Recently, it has been shown that between 1991 and 2000, foliar P concentrations of beech in Central Europe decreased by $13 \%$ as a result of chronic high $\mathrm{N}$ deposition (Talkner et al. 2015), which has been estimated at $25 \mathrm{~kg} \mathrm{~N} \mathrm{ha}^{-1}$ year $^{-1}$ in our site (Builtjes et al. 2011). This effect of high $\mathrm{N}$ deposition on foliar $\mathrm{P}$ concentrations of beech is probably the reason for the generally low leaf litter P contents found in our plots and those studied by Guckland et al. (2009) in Hainich, Germany.

$\mathrm{K}$ content in leaf litterfall at our site (Table 2.2) was within the range of all other temperate deciduous forests that we compared (12.3 - 25.6 $\mathrm{kg} \mathrm{P} \mathrm{ha}^{-1} \mathrm{year}^{-1}$; Gosz et al. 1972; Peterson and Rolfe 1982; Duchesne et al. 2001). The reported range of leaf litter K content is wide, possibly because $K$ adsorption in the soil strongly depends on soil texture and parent material (Ellis and Foth 1996) and tree tissue $\mathrm{K}$ concentrations often respond to soil exchangeable K (Tripler et al. 2006).

Our measured $k$ values (Fig. 2.1) vary above and below the reported mean $k$ value for temperate forests of $0.0021 \mathrm{~d}^{-1}$ (Swift et al. 1979). Higher values in the temperate zone have been reported, e.g. for ash trees at Hainich, Germany $\left(0.0085 \mathrm{~d}^{-1}\right.$; Jacob et al. 2009) or fig trees in China $\left(0.014 \mathrm{~d}^{-1}\right.$; Huang et al. 2007). Oriental beech (Fagus orientalis) in Turkey (0.0004 $\mathrm{d}^{-1}$; Kara et al. 2014) and American beech (Fagus grandifolia) in southwestern Quebec, Canada (0.0006 $\mathrm{d}^{-1}$; Trofymow et al. 2002) showed $k$ values similar to European beech (Fagus sylvatica) in our site (0.0006 $\mathrm{d}^{-1}$; Fig. 2.1), whereas $k$ as low as $0.0001 \mathrm{~d}^{-}$ ${ }^{1}$ was reported for American beech in the Northwest Territories, Canada (Trofymow et al. 2002).

The critical C: $N$ ratios (between 27 and 43) of decomposing leaf litter that we observed were slightly lower than the reported critical C:N ratios (between 33 and 71) for leaf litter decomposition of a range of Canadian forests (Moore et al. 2006; 2011). Also the critical C:P ratios (between 527 and 1003) of decomposing leaf litter that we observed tended to be lower than the C:P ratios in the same Canadian forests (between 700 and 1200). When comparing the critical C:N (27) and C:P ratios (586) of European beech leaf litter in our site with the critical values of American beech leaf litter in the Canadian forests ( $\mathrm{C}: \mathrm{N}$ ratios of 48-66 and C:P ratios of 682-821; Moore et al. 2006; 2011), this trend of lower ratios in our 
site persists. Higher availability of $\mathrm{N}$ in the soil has been suggested to decrease critical C:N ratios of decomposing leaf litter, although the exact mechanism is still debated (e.g. through a lower decomposer C:N ratio and/or through changes in the decomposers' $\mathrm{N}$ response efficiency; Ågren et al. 2013). While for the Canadian studies, plant-available $\mathrm{P}$ is not reported, several studies have shown that higher temperatures may increase $P$ availability through enhanced mineralization of organic $P$ (e.g. Vincent et al. 2014), and thus the lower critical C:P ratios in our site may be partly due to higher temperatures at our site than at the Canadian forests. Furthermore, critical C:N and C:P ratios of decomposing leaf litter have been shown to be positively correlated with the initial C:N and C:P ratios of leaf litter (Manzoni et al. 2010; Moore et al. 2011; Ågren et al. 2013). Thus, the lower critical C:N ratios of decomposing leaf litter in our site may be also contributed by the lower initial C: $\mathrm{N}$ ratios of leaf litter in our site (Table 2.1) as compared to C: $\mathrm{N}$ ratios of 39 - 83 in the Canadian forests (Moore et al. 2006; 2011).

We focus our comparison of foliar nutrient concentration with other studies only on foliar P level of beech trees because this parameter responded positively to the mixing of tree species. The foliar $P$ level of beech (Appendix 2.II) generally agreed with reported values from other studies (e.g. beech trees in Switzerland with $1.08-1.25 \mathrm{mg} \mathrm{P} \mathrm{g}^{-1}$ (Flückiger and Braun 1998) and in France with 1.06 ( $\pm 0.07 \mathrm{SE}$ ) $\mathrm{mg} \mathrm{P} \mathrm{g}^{-1}$ (Duquesnay et al. 2000)). Average foliar P levels of beech stands in Europe ranged from 0.81 $1.66 \mathrm{mg} \mathrm{g}^{-1}$ (Talkner et al. 2015), which are also on the deficient to normal levels based on the values reported by van den Burg (1985; 1990; as cited by Mellert and Göttlein 2012).

\subsubsection{Role of tree species on leaf litter nutrient content, decomposition rate (k) and annual net nutrient change}

Tree species clearly influenced leaf litter nutrient input to the soil, $k$ and annual net nutrient change of decomposing leaf litter, which were also reflected in soil available nutrients and foliar nutrient levels. This was signified by the highest leaf litter nutrient contents (N, P and $\mathrm{K}$ ) in hornbeam and the lowest in beech (Table 2.2). The mixed-species stands followed the trends of these two species' contrasting leaf litter nutrient contents (Table 2.2) and quality (i.e. leaf litter C:nutrient ratios; Table 2.1). Lime and oak were intermediary in leaf litter N, P and K contents between hornbeam and beech and these species' effects in mixed-species stands were clearly additive: when hornbeam and lime were mixed with either beech or oak, leaf litter nutrient inputs tended to be higher than when beech was mixed with oak and lime (Table 2.2). Similarly, $k$ (Fig. 2.1) and patterns of nutrient change in the decomposing leaf litter (Table 2.3 and Fig. 2.2) followed analogous additive effects of the types of tree 
species: highest $k$ values and net mineralization of nutrients in hornbeam and lime stands, lowest $k$ values and net immobilization of nutrients in beech stands, and higher $k$ and net mineralization of nutrients in mixed-species stands with hornbeam and/or lime than with beech and/or oak. The trends in $k$ values and nutrient change in decomposing leaf litter were reflected in the trends of the plant-available nutrient in the soil (i.e. higher plant-available $\mathrm{P}$ in the soil of hornbeam than beech stands; Table 2.1) and foliar nutrient levels (i.e. increased foliar P concentrations of beech when mixed with lime; Appendix 2.II). Altogether, our results showed that cycling of nutrients through leaf litter input and decomposition were influenced by the types of tree species and not simply by tree species diversity.

A recent review on the effects of mixed-species leaf litters on decomposition rates found that in $50 \%$ of the studies decay rates of mixed-species leaf litters were faster than expected from those of mono-species leaf litters, whereas in $20 \%$ of the studies decay rates were slower than expected, and the remaining studies showed no effect of mixed-species leaf litters (Richards et al. 2010). Additionally, a study from Hainich, Germany that included mono-species stands of beech and mixed-species stands of beech, maple, hornbeam, lime and ash found that decomposition rates is explained by the contributing tree species and not by the number of species included in the mixed stands (Jacob et al. 2010). These studies reinforced our findings that species diversity per se does not affect $k$ but instead the types of tree species.

\subsubsection{Competition between trees and microbial biomass for nutrients}

It is expected that trees will have high resorption for a nutrient with low availability in the soil (Han et al. 2013), and such nutrient will have the tendency to show net immobilization in the decomposing litter (Prescott 2005). Thus, trees and microbial biomass may have competed for nutrients when nutrient resorption efficiency by trees is negatively related to net nutrient change in decomposing leaf litter (i.e. third row in Fig. 2.3). Similarly, tree-microbial biomass competition may have occurred when nutrient resorption efficiency is negatively related to nutrient availability in the soil (i.e. fourth row in Fig. 2.3) if the soil nutrient availability reflects the net nutrient change in decomposing leaf litter (second row in Fig. 2.3). A co-occurrence of these relationships suggests highly coupled processes of nutrient resorption, leaf litter nutrient input, decomposition and availability of nutrients in the soil.

Several lines of evidence suggest that trees and microbial biomass were competing strongly for $\mathrm{P}$, less for $\mathrm{K}$ and only marginally for $\mathrm{N}$. For $\mathrm{P}, 46 \%$ of the leaf litter bags displayed net $\mathrm{P}$ immobilization at some point during the in-situ decomposition (Fig. 2.2), which was related to high leaf litter C:P ratios 
(first row in Fig. 2.3). The negative relationships of $P$ resorption efficiency by trees with net $P$ change in decomposing leaf litter and plant-available $\mathrm{P}$ in the soil (third and fourth rows in Fig. 2.3), as well as the positive relationship between plant-available $\mathrm{P}$ and net $\mathrm{P}$ change (second row in Fig. 2.3), indicated that $\mathrm{P}$ dynamics during decomposition influenced not only $\mathrm{P}$ availability in the soil but also the efficiency with which trees resorbed $\mathrm{P}$ prior to leaf shedding. This is best illustrated by the contrasting $\mathrm{P}$ dynamics in beech and oak stands from those in lime and hornbeam stands; beech and oak were among those with the highest $P$ resorption efficiencies and also displayed the highest net $P$ immobilization (i.e. most negative net $\mathrm{P}$ change values; Fig. 2.3 ), and the converse was true for lime and hornbeam. It is also mirrored in the lowest values of foliar P concentrations found in beech (Table 2.1). This supported our earlier findings that $P$ availability limits the growth of beech stands at our site (Schmidt et al. 2015). Altogether these results strongly suggest that at our site, particularly in the mono-species stands of beech and oak with the highest leaf litter C:P ratios (Table 2.1), lowest decomposition rates (Fig. 2.1) and highest $\mathrm{P}$ resorption efficiencies by trees (Fig. 2.3), there was a strong competition for $\mathrm{P}$ between trees and microbial biomass. To our knowledge, this is the first time that competition for available $\mathrm{P}$ in the soil has been shown in temperate forests.

We did not detect net $\mathrm{K}$ immobilization in any of the leaf litter bags during the entire period of in-situ decomposition (Figs. 2.2 and 2.3). A similar finding was reported for temperate upland and floodplain forests in Illinois, USA (Peterson and Rolfe 1982). In contrast to $P$ and $N$, most of the $K$ in leaves occurs in ionic form $\left(\mathrm{K}^{+}\right)$(Osman 2013), where it plays a role in the opening and closing of stomata. Since ionic $\mathrm{K}$ in its hydrated form is very mobile, much of it is leached from the leaves (Lukac and Godbold 2011) and released during decomposition (Peterson and Rolfe 1982). This high mobility of $\mathrm{K}$ from leaves and decomposing leaf litter is manifested in our findings: resorption efficiencies for $\mathrm{K}$ by trees were low and net $\mathrm{K}$ change during leaf litter decomposition was consistently positive (net $\mathrm{K}$ mineralization) across all stands (third row in Fig. 2.3). Nonetheless, the relationships of $\mathrm{K}$ resorption efficiency with net $K$ change and exchangeable $K$ in the soil (third and fourth rows in Fig. 2.3) suggest slight competition between trees and microbial biomass, particularly for the beech stands which exhibited high $\mathrm{K}$ resorption efficiency and low net $\mathrm{K}$ change in decomposing leaf litter (third row in Fig. 2.3). This also supports our earlier findings that $K$ availability limits the growth of beech stands at our site (Schmidt et al. 2015).

Although $69 \%$ of the leaf litter bags displayed net $\mathrm{N}$ immobilization at some point during the insitu decomposition (Fig. 2.2), there was no relationship observed between $\mathrm{N}$ resorption efficiency by trees and plant-available $\mathrm{N}$ in the soil (fourth row in Fig. 2.3) or between plant-available $\mathrm{N}$ and net $\mathrm{N}$ 
change in decomposing leaf litter (second row in Fig. 2.3). This was probably related to the high historic and present atmospheric $\mathrm{N}$ deposition at our site, which is about $25 \mathrm{~kg} \mathrm{ha}^{-1}$ year $^{-1}$ in recent years (Builtjes et al. 2011). Atmospheric $N$ deposition not only increases $N$ availability (Bobbink et al. 2010), it has also been shown to alleviate $\mathrm{N}$ limitation to microbial activity on soil-N cycling processes (Corre et al. 2003; 2007; Corre and Lamersdorf 2004). In our present study, the negative relationship between $\mathrm{N}$ resorption efficiency by trees and net $\mathrm{N}$ change in decomposing leaf litter (third row in Fig. 2.3) suggests a slight competition between trees and the microbial biomass, particularly in beech and oak stands that showed temporary net $\mathrm{N}$ immobilization within a year of leaf litter decomposition (Table 2.3). However, chronic high $\mathrm{N}$ deposition at our site may have led to a decoupling of $\mathrm{N}$ dynamics during leaf litter decomposition from $\mathrm{N}$ availability in the soil. This also supported our earlier findings where availability of $\mathrm{N}$ in the soil did not limit tree growth in any of the stands at our site (Schmidt et al. 2015), which is in contrast to an earlier study showing competition for $\mathrm{N}$ availability between beech trees and microbial biomass in a site with relatively low $\mathrm{N}$ deposition (< $10 \mathrm{~kg} \mathrm{~N} \mathrm{ha}^{-1}$ year $^{-1}$; Dannenmann et al. 2008; Dannenmann et al. 2009).

\subsection{Implications and conclusions}

Tree-microbial biomass competition for available nutrients depended on the types of tree species in a given stand. Leaf litter from mixed-species stands with high leaf litter quality and nutrient content, such as hornbeam and lime, resulted in additive effects on nutrient release during leaf litter decomposition, on nutrient availability in the soil and, correspondingly, on foliar nutrient level. In contrast to our first hypothesis, tree species diversity per se did not enhance nutrient turnover of leaf litter since the effects of tree species compositions were species-specific. In support of our second hypothesis, our findings showed evidence of strong competition between trees and microbial biomass for $\mathrm{P}$, less for $\mathrm{K}$ and only marginally for $\mathrm{N}$. Such competition was most pronounced in mono-species stands of beech and oak.

It is likely that competition for nutrients has changed over the past decades due to the impact of anthropogenic $\mathrm{N}$ deposition. Chronic high N deposition has increased soil N availability (Corre et al. 2003; 2007) and this has alleviated $\mathrm{N}$ limitation to tree growth but reduced foliar $\mathrm{P}$ concentrations in central European forests (Bobbink et al. 2010; Talkner et al. 2015). P and $\mathrm{K}$ limitations on growth of beech stands at Hainich, Germany are thus a relatively new feature that may require adapted management, e.g. mixing with hornbeam and lime to alleviate $\mathrm{P}$ and $\mathrm{K}$ deficiency of beech trees. These species-specific 
effects on nutrient cycling and soil nutrient availability can aid forest management in improving productivity and soil fertility.

\section{Acknowledgements}

This study was funded by the German Research Foundation (DFG, Research Training Group $1086 / 2-3$, The role of biodiversity for biogeochemical cycles and biotic interactions in temperate deciduous forests, Subproject B7). The Buesgen Institute - Bioclimatology, Georg-August University of Goettingen provided the soil temperature data of our study site, Wiebke Schrell, Johannes Persch and Frederic Fischer conducted their BSc research in the framework of our study. We thank the national park authorities for allowing access to the site. The help of the laboratory technicians of SSTSE (K. Langs, A. Bauer, M. Knaust and D. Böttger) is highly appreciated.

\section{References}

Aerts R 1996 Nutrient Resorption from Senescing Leaves of Perennials: Are there General Patterns? J Ecol 84, 597608

Aerts R 1997 Nitrogen Partitioning between Resorption and Decomposition Pathways: A Trade-Off between Nitrogen Use Efficiency and Litter Decomposibility? Oikos 80, 603-606

Ågren G I, Hyvönen R, Berglund S L, Hobbie S E 2013. Estimating the critical N:C from litter decomposition data and its relation to soil organic matter stoichiometry. Soil Biol Biochem 67, 312-318

Aitken M, Broadhurst B, Hladky S 2009 Mathematics for Biological Scientists. Taylor \& Francis, New York, NY

Bärlocher F 2005. Leaf mass loss estimated by litter bag technique. Eds. M A S Graça, Bärlocher F, Gessner M O. pp. 37-42. Springer, Dordrecht.

Berg B, Laskowski R 2006. Litter Decomposition: A Guide to Carbon and Nutrient Turnover. Academic Press, Amsterdam

Berg B, McClaugherty C.A., 2003. Plant Litter: Decomposition, Humus Formation, Carbon Sequestration. Springer, Berlin Heidelberg

Bloemhof H S, Berendse F 1995 Simulation of the decomposition and nitrogen mineralization of aboveground plant material in two unfertilized grassland ecosystems. Plant Soil 177, 157-173

Bobbink R, Hicks K, Galloway J, Spranger T, Alkemade R, Ashmore M, Bustamante M, Cinderby S, Davidson E, Dentener F, Emmett B, Erisman J-W, Fenn M, Gilliam F, Nordin A, Pardo L, De Vries W 2010 Global assessment of nitrogen deposition effects on terrestrial plant diversity: a synthesis. Ecol Appl 20, 30-59

Braun S, Thomas, V F D, Quiring R, Flueckiger W 2010 Does nitrogen deposition increase forest production? The role of phosphorus. Environ Pollut 158, 2043-2052

Builtjes P, Hendriks E, Koenen M, Schaap M, Banzhaf S, Kerschbaumer A, Gauger T, Nagel H D, Scheuschner T, Schlutow A 2011 Erfassung, Prognose und Bewertung von Stoffeinträgen und ihren Wirkungen in Deutschland-Zusammenfassender Abschlussbericht. Umweltbundesamt, Dessau-Rosslau, Appendix 11

Chapin III F S, Matson P A, Vitousek P 2011 Principles of Terrestrial Ecosystem Ecology. Springer, New York, NY 
Corre M D, Beese F O, Brumme R 2003 Soil nitrogen cycle in high nitrogen deposition forest: changes under nitrogen saturation and liming. Ecol Appl 13, 287-298

Corre M D, Lamersdorf N P 2004. Reversal of nitrogen saturation after long-term reduction of nitrogen deposition: changes in the soil nitrogen cycle. Ecology 85, 3090-3104

Corre M D, Brumme R, Veldkamp E, Beese F O 2007 Changes in nitrogen cycling and retention processes in soils under spruce forests along a nitrogen enrichment gradient in Germany. Glob Change Biol 13, 1509-1527

Dannenmann M, Butterbach-Bahl K, Gasche R, Willibald G, Papen H 2008 Dinitrogen emissions and the $\mathrm{N}_{2}: \mathrm{N}_{2} \mathrm{O}$ emission ratio as influenced by $\mathrm{pH}$ and forest thinning. Soil Biol Biochem 40, 2317-2323

Dannenmann M, Simon J, Gasche R, Holst J, Naumann P S, Kögel-Knabner I, Knicker H, Mayer H, Schloter M, Pena R, Polle A, Rennenberg H, Papen H 2009 Tree girdling provides insight on the role of labile carbon in nitrogen partitioning between soil microorganisms and adult European beech. Soil Biol Biochem 41, 1622-1631

Duchesne L, Ouimet R, Camiré C, Houle D 2001 Seasonal nutrient transfers by foliar resorption, leaching, and litter fall in a northern hardwood forest at Lake Clair Watershed, Quebec, Canada. Can J Forest Res 31, 333344

Duquesnay A, Dupouey J L, Clement A, Ulrich E, Le Tacon F 2000 Spatial and temporal variability of foliar mineral concentration in beech (Fagus sylvatica) stands in northeastern France. Tree Physiol 20, 13-22.

Ellis B, Foth H 1996 Soil Fertility. CRC Press, Boca Raton, FL

Fox J, Weisberg S, 2011 An $\{\mathrm{R}\}$ Companion to Applied Regression, Second Edition. Thousand Oaks, CA: Sage. http://socserv.socsci.mcmaster.ca/jfox/Books/Companion

Flückiger W, Braun S 1998 Nitrogen deposition in Swiss forests and its possible relevance for leaf nutrient status, parasite attacks and soil acidification. Environ Pollut, Nitrogen, the Confer-N-s First International Nitrogen Conference 1998 102, 69-76

Fritzlar D, Biehl H 2006 Buchenplenterwald Hainich. Schutzgemeinschaft Deutscher Wald. Landesverband Thüringen e.V., Weinbergen

Gosz J R., Likens G E, Bormann F H 1972 Nutrient Content of Litter Fall on the Hubbard Brook Experimental Forest, New Hampshire. Ecology 53, 770-784

Guckland A, Jacob M, Flessa H, Thomas F M, Leuschner C 2009 Acidity, nutrient stocks, and organic-matter content in soils of a temperate deciduous forest with different abundance of European beech (Fagus sylvatica L.). J Plant Nutr Soil Sc 172, 500-511

Han W, Tang L, Chen Y, Fang J, 2013 Relationship between the Relative Limitation and Resorption Efficiency of Nitrogen vs Phosphorus in Woody Plants. PLoS ONE 8, e83366

Hodge A, Robinson D, Fitter A 2000 Are microorganisms more effective than plants at competing for nitrogen? Trends Plant Sci 5, 304-308

Hothorn T, Bretz F, Westfall P, 2008. Simultaneous Inference in General Parametric Models. Biometrical J 50, $346-$ 363

Huang J, Wang X, Yan E 2007 Leaf nutrient concentration, nutrient resorption and litter decomposition in an evergreen broad-leaved forest in eastern China. Forest Ecol Manag 239, 150-158

Ilg K, Wellbrock N, Lux W 2009 Phosphorus supply and cycling at long-term forest monitoring sites in Germany. Eur J For Res 128, 483-492

Jacob M, Weland N, Platner C, Schaefer M, Leuschner C, Thomas F M 2009 Nutrient release from decomposing leaf litter of temperate deciduous forest trees along a gradient of increasing tree species diversity. Soil Biol Biochem 41, 2122-2130

Jacob M, Viedenz K, Polle A, Thomas F M 2010 Leaf litter decomposition in temperate deciduous forest stands with a decreasing fraction of beech (Fagus sylvatica). Oecologia 164, 1083-1094 
Jonard M, Andre F, Dambrine E, Ponette Q, Ulrich E 2009 Temporal trends in the foliar nutritional status of the French, Walloon and Luxembourg broad-leaved plots of forest monitoring. Ann For Sci 66, 412

Kara O, Bolat I, Cakıroglu K, Senturk M 2014 Litter Decomposition and Microbial Biomass in Temperate Forests in Northwestern Turkey. J Soil Sci Plant Nutr 14, 31-41

Kim S 2012 ppcor: Partial and Semi-partial (Part) correlation. R package version 1.0. http://CRAN.Rproject.org/package=ppcor

Kobe R K, Lepczyk C A, lyer M 2005 Resorption efficiency decreases with increasing green leaf nutrients in a global data set. Ecology 86, 2780-2792

Lukac M, Godbold D L 2011 Soil ecology in northern forests: a belowground view of a changing world. Cambridge University Press

Manzoni S, Trofymow J A, Jackson R B, Porporato A 2010 Stoichiometric controls on carbon, nitrogen, and phosphorus dynamics in decomposing litter. Ecol Monogr 80, 89-106

Mellert K H, Goettlein A 2012 Comparison of new foliar nutrient thresholds derived from van den Burg's literature compilation with established central European references. Eur J For Res 131, 1461-1472

Mölder A, Bernhardt-Römermann M, Schmidt W 2006 Forest ecosystem research in Hainich National Park (Thuringia): first results on flora and vegetation in stands with contrasting tree species diversity. Waldökologie online 3, 83-99

Moore A M 1986 Temperature and moisture dependence of decomposition rates of hardwood and coniferous leaf litter. Soil Biol Biochem 18, 427-435

Moore T R, Trofymow J A, Prescott C E, Fyles J, Titus B D 2006 Patterns of Carbon, Nitrogen and Phosphorus Dynamics in Decomposing Foliar Litter in Canadian Forests. Ecosystems 9, 46-62

Moore T R, Trofymow J A, Prescott C E, Titus B D, Group C W 2011 Nature and nurture in the dynamics of C, N and P during litter decomposition in Canadian forests. Plant Soil 339, 163-175-3

Osman K T 2013 Forest Soils. Springer International

Perakis S S, Hedin L O 2001 Fluxes and fates of nitrogen in soil of an unpolluted old-growth temperate forest, southern Chile. Ecology 82, 2245-2260

Peterson D L, Rolfe G L 1982 Nutrient Dynamics and Decomposition of Litterfall in Floodplain and Upland Forests of Central Illinois. Forest Sci 28, 667-681

Prescott C E 2005 Do rates of litter decomposition tell us anything we really need to know? Forest Ecol Manag 220, 66-74

Prescott C E 2010 Litter decomposition: what controls it and how can we alter it to sequester more carbon in forest soils? Biogeochemistry 101, 133-149

R Development Core Team 2013 R: A language and environment for statistical computing. R Foundation for Statistical Computing, Vienna, Austria. http://www.r-project.org

Richards A E, Forrester D I, Bauhus J, Scherer-Lorenzen M 2010 The influence of mixed tree plantations on the nutrition of individual species: a review. Tree Physiol 30, 1192-1208

Rothe A, Binkley D 2001 Nutritional interactions in mixed species forests: a synthesis. Can J Forest Res 31, 18551870

Schmidt M, Veldkamp E, Corre M D 2015 Tree species diversity effects on productivity, soil nutrient availability and nutrient response efficiency in a temperate deciduous forest. Forest Ecol Manag 338, 114-123

Swift M J, Heal O W, Anderson J M 1979 Decomposition in Terrestrial Ecosystems. University of California Press

Talkner U, Meiwes K J, Potočić N, Seletković I, Cools N, Vos B D, Rautio P 2015 Phosphorus nutrition of beech (Fagus sylvatica L.) is decreasing in Europe. Ann For Sci 1-10 
Tripler C E, Kaushal S S, Likens G E, Todd Walter M 2006 Patterns in potassium dynamics in forest ecosystems. Ecol Lett 9, 451-466

Trofymow J A, Moore T R, Titus B, Prescott C, Morrison I, Siltanen M, Smith S, Fyles J, Wein R, Camiré C, Duschene L, Kozak L, Kranabetter M, Visser S 2002 Rates of litter decomposition over 6 years in Canadian forests: influence of litter quality and climate. Can J Forest Res. 32, 789-804

van den Burg J 1985 Foliar analysis for determination of tree nutrient status - A compilation of literature data. Rijksinstituut voor onderzoek in de bos- en landschapsbouw "de Dorschkamp", Wageningen

van den Burg J 1990 Foliar analysis for determination of tree nutrient status - A compilation of literature data; 2. Literature 1985-1990. "de Dorschkamp" Institute for Forestry and Urban Ecology, Wageningen

Vincent A G, Sundqvist M K, Wardle D A, Giesler R 2014 Bioavailable Soil Phosphorus Decreases with Increasing Elevation in a Subarctic Tundra Landscape. PLoS One 9. doi:10.1371/journal.pone.0092942

Yamashita N, Ohta S, Hardjono A 2008 Soil changes induced by Acacia mangium plantation establishment: Comparison with secondary forest and Imperata cylindrica grassland soils in South Sumatra, Indonesia. Forest Ecol Manag 254, 362-370 


\section{Appendix 2.I}

Correlation coefficients of decomposition rates, $k$, with leaf litter quality, soil biochemical properties and plant-available nutrients in the soil, using the mean values for each mono- and mixed species stand type.

\begin{tabular}{|c|c|c|}
\hline$k$ versus & Parameter & $\mathrm{R}$ \\
\hline \multicolumn{3}{|c|}{ leaf litter quality } \\
\hline & $\mathrm{C}: \mathrm{N}$ ratio & -0.79 ** \\
\hline & $\mathrm{N}: \mathrm{P}$ ratio & $-0.67^{*}$ \\
\hline & $\mathrm{N}$ & $0.80^{* *}$ \\
\hline & $P$ & $0.84^{* * *}$ \\
\hline & $\mathrm{K}$ & 0.72 * \\
\hline & $\mathrm{Ca}$ & $0.92^{* * *}$ \\
\hline & $\mathrm{Mg}$ & $0.86^{* * *}$ \\
\hline \multicolumn{3}{|c|}{ Soil biochemical properties } \\
\hline & $\mathrm{C}: \mathrm{N}$ ratio & $-0.71 *$ \\
\hline & $\mathrm{N}: \mathrm{P}$ ratio & $-0.61 \dagger$ \\
\hline & $\mathrm{pH}\left(\mathrm{H}_{2} \mathrm{O}\right)$ & 0.70 * \\
\hline \multicolumn{3}{|c|}{ Plant-available nutrients in soil } \\
\hline & Plant-available N & 0.34 \\
\hline & Plant-available P & -0.19 \\
\hline & Exchangeable $\mathrm{K}$ & 0.33 \\
\hline & Exchangeable $\mathrm{Ca}$ & $0.88^{* *}$ \\
\hline & Exchangeable Mg & $0.65 \dagger$ \\
\hline
\end{tabular}

$\mathrm{n}=8$ stand types

${ }^{* * *} P \leq 0.001,{ }^{* *} P \leq 0.01,{ }^{*} P \leq 0.05$, and $\dagger P \leq 0.1$, based on partial Pearson correlation test with clay content as control variable 


\section{Appendix 2.II}
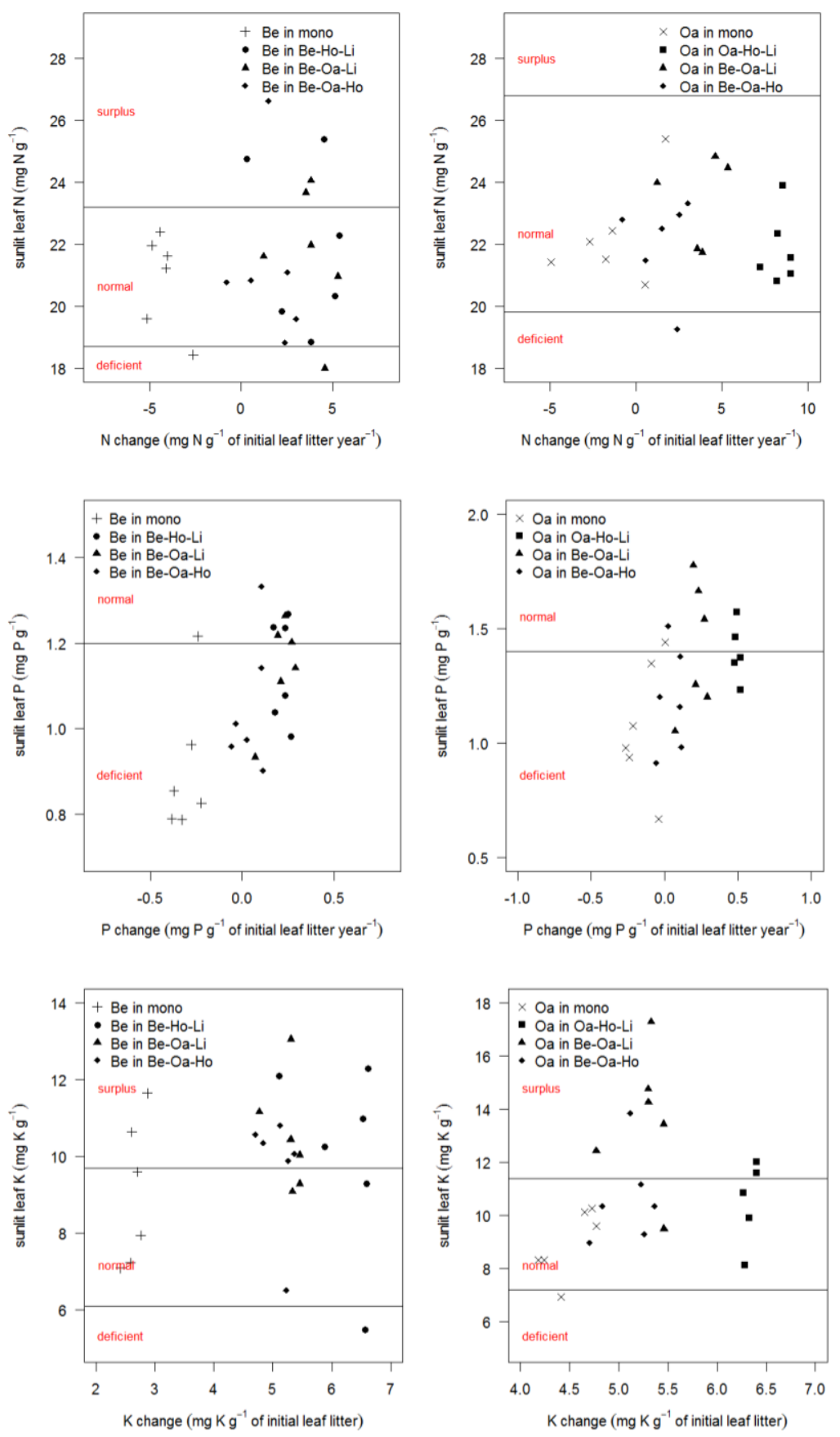

Sunlit leaf concentrations of nitrogen ( $\mathrm{N}$; top row), phosphorus ( $\mathrm{P}$; middle row) and potassium (K, bottom row) in beech (Be; left column) and oak trees (Oa; right column) in their mono- and mixed-species stands with hornbeam (Ho) and lime (Li), measured in 2013. Nutrient change in decomposing leaf litter $=t_{0}-t_{i} ; t_{0}=$ initial nutrient concentration; $t_{1}=$ nutrient concentration at 371 days of incubation $\mathrm{x}$ remaining leaf litter mass $\mathrm{x}$ initial leaf litter mass ${ }^{-1}$. Marked ranges for deficient, normal and surplus levels of foliar $\mathrm{N}, \mathrm{P}$ and K are taken from van den Burg $(1985,1990$, as cited by Mellert and Göttlein 2012). 
Chapter 3 


\title{
3. Tree neighborhood dynamics of beech, oak, hornbeam and lime in a temperate deciduous forest
}

\author{
Marcus Schmidt, Edzo Veldkamp, Marife D. Corre
}

\begin{abstract}
In the few undisturbed temperate deciduous forests left in Central Europe, beech is generally more dominant than oak, but may be outcompeted by oak where conditions are dry. However, abundance of oak is declining, possibly related to high $\mathrm{N}$ deposition. We aim to investigate whether in recent decades, the relative competitiveness of oak declined due to $\mathrm{N}$ deposition. Furthermore, we are interested in how intraspecific vs. interspecific competition affects neighboring trees and stand development. In mono- and mixed-species stands including beech, oak, hornbeam and lime as well as mixes of three of these species, we assessed diameter distribution for each species and above-ground woody biomass (AWB) for all species compositions. We also constructed polygons around each tree to indicate whether a tree species increases its area of potential below-ground resource acquisition. Pairs of nearest neighbors were detected to assess above-ground competitiveness between species. Stem diameter at breast-height ( $\mathrm{dbh}$ ) was used as a proxy for time in a modified time-for-space approach. Above-ground woody biomass was largest for beech, oak and lime and lowest for hornbeam with intermediate biomass for mixed-species stands. With the exception of oak, all species were able to increase their growing space with dbh. In intraspecific nearest-neighborhoods, neighbors had the same $\mathrm{dbh}$ and tended to increase their $\mathrm{dbh}$ with that of their neighbor. In contrast, in interspecific nearest neighborhoods, neighbor $\mathrm{dbh}$ generally differed and neighbor $\mathrm{dbh}$ decreased with $\mathrm{dbh}$ of a target tree. Oak trees were not able to increase growing space with dbh but dominated in size over their nearest neighbors. We concluded that remaining oak trees were most competitive for light. However, little rejuvenation of oak speaks for $\mathrm{N}$ deposition effects but may also be due to history of use. In any case, beech was likely left to dominate the studied forest ecosystem. At Hainich, interspecific competition was greater than intraspecific competition. There was indication that as a result, mono-species stands of beech, oak and lime formed high-biomass climax stands in a shifting small-scale mosaic of compositions.
\end{abstract}




\subsection{Introduction}

There are many factors that influence the tree composition of temperate deciduous forests. Biological interactions (i.e., micorrhizal association), seed dispersal, disturbance events or a fitting place in the heterogenious vertical structure of a forest all affect whether an individual tree will be established (Nakashizuka 2001). In addition, the presence of deadwood has been shown to create small-scale variability in soil nutrient concentrations, meeting the requirements of different species (Burrascano et al. 2008). Following establishment, the abudance of a species depends on its ability to compete with other species as well as its vulnerability towards pathogens and herbivores (Crawley 1997). Temperate deciduous forests finally reach a 'shifting mosaic steady state' of different tree ages and compositions (Emborg et al. 2000). In Central Europe, beech appears to dominate over oak. Aside from strongly lightrelated competitive pressure of beech towards oak demonstrated in an an old-growth forest of western Romania (Petritan et al. 2014) and in a study comprising 50 years of forest succession in Switzerland (Rohner et al. 2012), declining presence of oak in European forests (Oszaka 1997), may also be related to the combined effects of excess nitrogen deposition and drought stress, as was suggested for $Q$. robur (Thomas et al. 2002).

Trees compete by trying to aquire the same resources as their neighbor (Crawley 1997). The three main components of competition are genetic and micro-environmental influences, general environment and local neighbor influence (Tomé and Burkhart 1989). Intraspecific competition between trees is thought to be stronger than competition between different tree species, which is often explained by the different shapes of crown and roots as well as different heights in interspecific combinations (Röhrig et al. 2006; Begon et al. 2006). However, there are also examples where trees may profit from stands of their own species: e.g. beech creates shade which puts its own saplings in advantage (von Wuelisch 2008). In contrast, oak saplings profit from the the relatively open crown of mature oak trees, since they depend more strongly on light (Ellenberg and Leuschner 2010).

In Central Europe, the potential vegetation of large areas are forests dominated by beech and mixed beech forests (Bohn et al. 2000). Because of the intensive use at present and in the past, oldgrowth temperate deciduous forests have virtually disappeared in Europe. Nowadays the forests closest to old-growth forest are areas in protected national parks. Two examples are the world heritage sites of the Carpathians and the Hainich forest in Germany. At both sites, European beech (Fagus sylvatica), sessile oak (Quercus petraea) and European hornbeam (Carpinus betulus) are among the most abundant tree species (Nationalparkverwaltung Hainich 2008; Brändli et al. 2008). Earlier work has shown that unmanaged temperate deciduous forests may develop towards the dominance of beech (Saniga et al. 
2011; Petritan et al. 2014). Since beech occurs on a wide range of parent materials, it has been described as Central Europe's most successful plant species (Leuschner et al., 2006; Meier et al. 2005).

Furthermore, compared to oak, hornbeam and lime, beech has higher tolerance to shade, spring frost and drought. It also grows to greater size than hornbeam and lime. Beech creates more shade than oak and lime and tolerates winter frost better than lime. Beech trees have also been shown to profit from nutrients provided by other neighbouring tree species (Schmidt et al. 2015). On alkaline to acidic soils and in moist to moderately dry soils beech typically dominates and oak, hornbeam and lime only play a minor role. In drier areas, oak may be in advantage (Ellenberg and Leuschner 2010), while the shading leafs of beech have a disadvantage in drought resistance (Backes and Leuschner 2000).

Two GIS based methods to evaluate competitiveness of a species are: a) polygon analysis, which can be used as an indicator of growing space and thus the ability of a species to increase the amount of potentially available resources (Firbank and Watkinson 1987). When applying polygon analysis, it is assumed that trees compete for below-ground resources such as nutrients (Mead 1979) or water and, b) nearest neighbor analysis, which can be used as an indicator of competitive direction since competition acts from larger to smaller tree (Crawley 1990). It is assumed that nearest neighbor diameters (used in this study as a proxy for size) provide information on competition for light (Cooper 1961). However, it has been critizised that nearest-neighbor analysis ignores interactions further away (Moeur 1993). One other way to assess light competition, but more on a stand level, would be the use of a crown competition factor (Pretzsch 2009).

In the present study, our objective was to assess the relative competitiveness, intra- vs. interspecific competition and stand development of tree species in an unmanaged temperate deciduous forest in Germany. Relative competitiveness signifies the ability of a tree to increase growing space and dominate in size over a nearest neighbor and we evaluated this using growing space analysis and nearest neighbor analysis. We tested the following hypotheses (1) in recent decades the relative competitiveness of oak has declined due to increased $\mathrm{N}$ deposition and (2) for beech, oak, lime and hornbeam intraspecific competition is greater than interspecific competition. We also wanted to evaluate whether there is indication that (3) stands of different compositions represent stages in stand development. 


\subsection{Methods}

\subsubsection{Study area and approach}

The research was conducted in a unmanaged temperate forest stand of about 25 ha at Hainich national park in Central Germany near the town of Weberstedt $\left(51^{\circ} 6^{\prime} 0^{\prime \prime} \mathrm{N} 10^{\circ} 30^{\prime} 0^{\prime \prime} \mathrm{E}\right)$. We selected six replicates of stands with the following tree species compositions: mono species stands of beech (Fagus sylvatica), oak (Quercus petraea with few trees of Quercus robur), hornbeam (Carpinus betulus) and lime (mainly Tilia cordata, Rajendra 2009) as well as mixed species stands of 3 of the same species ( = 8 compositions $\times 6$ replicates $=48$ stands). Each stand consisted of 4-8 trees asssigned to that stand type, plus surrounding trees neccesarry to construct growing spaces (Mead 1966). Selecting each species in each possible species combination of three enabled us to assess the 'preferential' neighborhood during a species' life cycle. Direct observations on the dymanics of tree populations are difficult due to their long life span (Crawley 1997). Following the widely used space-for-time substitution (Picket 1989), we used a stem-size-for-time approach in order to study the dynamics of tree neighborhoods at different stem sizes representing time.

\subsubsection{Parameters of competitiveness, inter- vs. interspecific competition and stand development}

Above-ground woody biomass for each stand type was calculated by use of allometric equations (see Wirth et al. 2004 for beech and hornbeam, Cienciala et al. 2008 for oak and Bunce 1968 for lime). The woody biomass of the trees assigned to the stand, divided by the stand area comprised of each tree's growing space (see below; Fischer 2013). Diameter distribution was assessed for all trees with a complete polygon, i.e., sufficient mapped trees surrounding it $(n=198)$ and mean diameter witin stand types was assessed for those trees clearly assigned to a stand type $(n=208$; since a complete Voronoipolygon was not necessary in this case).

Growing spaces were constructed using Voronoi-polygons (Mead 1966; Şen 2009). The location of the center of each of our stands was meassured using a portalbe GPS device (GPSMAP 60CSx, Garmin, Schaffhausen, Switzerland). From this center, the distance to each tree immediately surrounding it and those behind was determined using an ultra-sonic measuring system (Vertex IV with transponder T3, Haglöf, Långsele, Sweden). A precision-compass (Suunto KB-14, Vantaa, Finland) was used to determine the angle of each tree with the center. From this information, north/southbound and east/westbound distance of the tree to the center was calculated using triangulation. The resulting distances were added 
to the Gauss-Krüger coordinates of the center, so that each tree had its own coordinates, which were entered into a geographic information system (GIS) (Quantum GIS, QGIS Development Team 2012, Fig. 3.1). Using the Quantum GIS function Vector - Geometry Tools - Voronoi Polygons, growing areas were automatically calculated (Persch 2013).

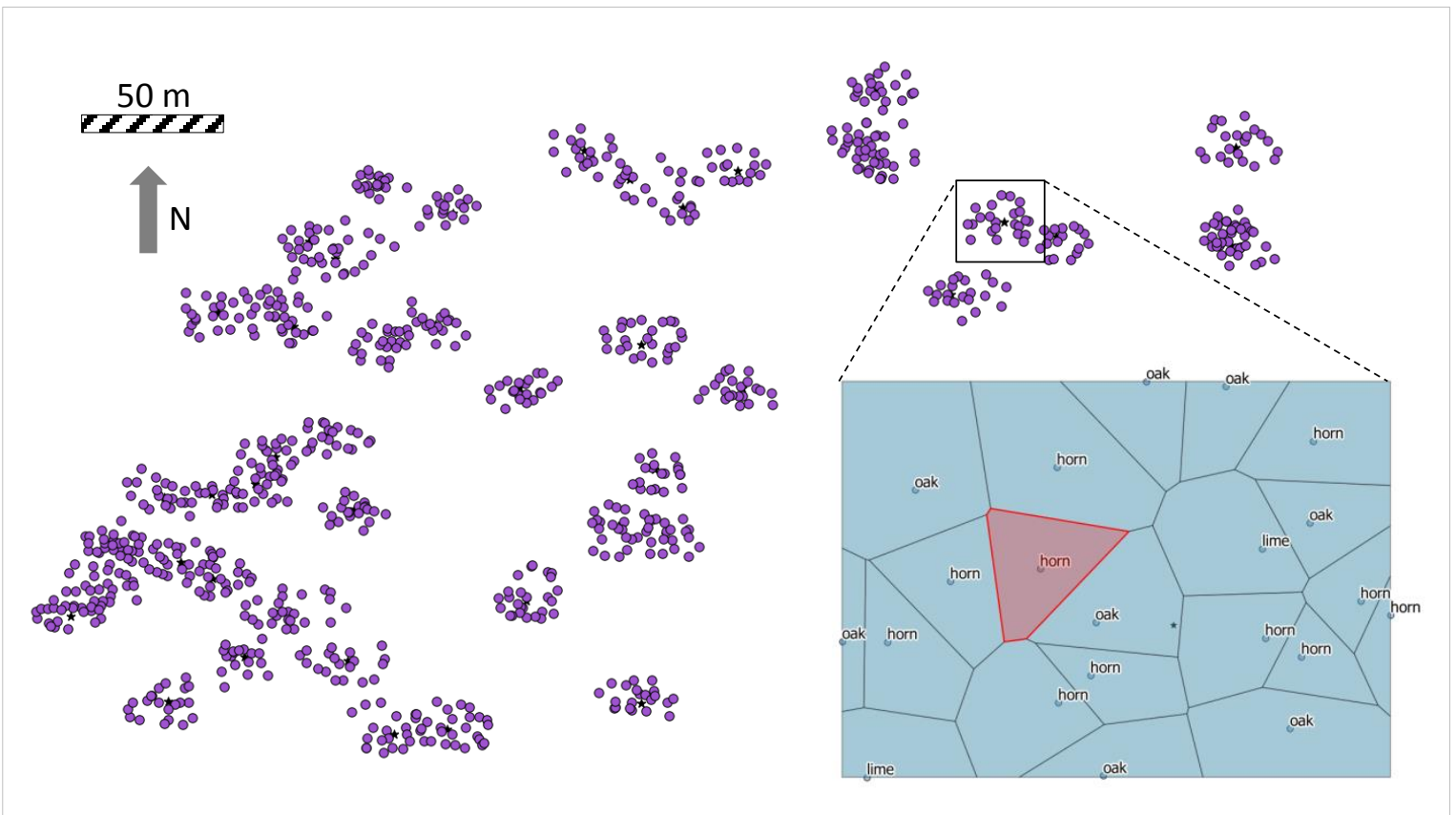

Fig. 3.1: Measured trees within mono- and mix-species stands at a temperate forest in Germany. Dots represent individual trees. The area enlarged represents one stand, with lines showing borders between growth polygons (based on Persch 2013).

In contrast to Clark \& Evans (1954), we used only one/the nearest neighbor per tree, because we were interested in specific pairs in order to achieve a competitive order. Also, methods such as a crown competition factor (Pretzsch 2009) were not used, because they provide a stand-level index of competition while we were interested in each combination of two species. We assigned nearest neighbors to all trees where a complete Voronoi-polygon could be constructed, i.e., all surrounding trees were mapped ( $n=198$ trees). To determine the nearest neighbor of a species and its distance, we used the tool Measure Line. Diameter at breast-height ( $\mathrm{dbh}$, also referred to here as diameter) for each individual tree was measured either with dendrometer bands (for selected trees composing a stand in 2012, D1, UMS GmbH, München) or manually in 2013 (for trees surrounding the selected trees). We determined mean $\mathrm{dbh}$ of each species in each nearest neighbor pair. Also, we analyzed how dbh of a neighboring species developed with dbh of the target species, independent of its distance. 


\subsubsection{Statistic Analysis}

For above-ground woody biomass, mean diameters within and across stand types and nearest neighbor dbh comparison, data were tested for normality and equality of variances using the Shapiro Wilk test and Levene's test (Fox and Weisberg 2011). If both requirements were met, stand type difference were determined by using ANOVA with a subsequent Tukey HSD test (Hothorn et al. 2008). In some cases, log or square-root transformations were used. If requirements were not met, we used the non-parametric Kruskal-Wallis $\mathrm{H}$ test with multiple comparison extension (Giraudoux 2014). Differences were accepted as significant at $P \leq 0.05$ and in a few cases as marginally significant at $P \leq 0.1$. Spearman correlations were used to correlate species' dbh and species' growing space. To independently assess relationships between a species' dbh its nearest neighbor's dbh (distance-independent), we used partial Spearman correlations (Kim 2012). All statistical analysis was done with R version 3.0.1 (R Development Core Team 2013).

\subsection{Results}

\subsubsection{Above-ground woody biomass of forest stands}

Above-ground woody biomass (AWB) for all 48 stands ranged from $13.3 \mathrm{~kg} \mathrm{~m}^{-2}$ to $108.4 \mathrm{~kg} \mathrm{~m}^{-2}$ with a mean of 44.0 (2.8 SE) kg m${ }^{-2}$ (equivalent to $440 \mathrm{t} \mathrm{ha}^{-1}$ ). Within mono-species stands, stands of beech, oak and lime had greater AWB than stands of hornbeam $(P<0.01$, Table 3.1). Mixed species stands did not differ in AWB $(P=0.37-1.00)$. Comparing mono- and mixed species stands, hornbeam mono-species stands had lower AWB than the mix of the other three species $(P=0.03)$. Also, beech mono-species stands had higher AWB than the mixes containing both hornbeam and lime $(P=0.01-$ 0.08) while lime mono-species stands showed higher AWB than the beech-hornbeam-lime mix $(P=0.08)$.

Table 3.1

Above-ground woody biomass in 2012 for different species compositions at Hainich forest

\begin{tabular}{|c|c|c|c|c|c|c|c|c|}
\hline Composition & Hornbeam & $\begin{array}{l}\text { Beech- } \\
\text { Hornbeam- } \\
\text { Lime }\end{array}$ & $\begin{array}{l}\text { Oak- } \\
\text { Hornbeam- } \\
\text { Lime }\end{array}$ & $\begin{array}{l}\text { Beech- } \\
\text { Oak- } \\
\text { Hornbeam }\end{array}$ & $\begin{array}{l}\text { Beech- } \\
\text { Oak- } \\
\text { Lime }\end{array}$ & Lime & Oak & Beech \\
\hline $\begin{array}{l}\text { AWB } \\
\left(\mathrm{kg} \mathrm{m}^{-2}\right)\end{array}$ & $\begin{array}{l}24.0(3.2) \\
d\end{array}$ & $\begin{array}{l}31.0(4.4) \\
\mathrm{cd}\end{array}$ & $\begin{array}{l}33.4(1.4) \\
\text { bcd }\end{array}$ & $\begin{array}{l}40.4(7.0) \\
\text { abcd }\end{array}$ & $\begin{array}{l}46.0(4.8) \\
a b c\end{array}$ & $\begin{array}{l}56.5(11.2) \\
a b\end{array}$ & $\begin{array}{l}58.1(6.3) \\
a b\end{array}$ & $\begin{array}{l}62.3(8.0) \\
a\end{array}$ \\
\hline
\end{tabular}

Means (SE, $n=6$ stands) with different letters indicate significant differences among species compositions (ANOVA with Tukey HSD test at $P=0.09)$, raw data from Fischer 2013. 


\subsubsection{Diameter distribution, stand type diameters and growing space development}

The abundance of beech, oak, hornbeam and lime differed in dbh classes of $5 \mathrm{~cm}$ (Fig. 3.2). There were no dbh classes in which beech trees were most abundant and it was the only species for which we measured diameters greater than the $65-70 \mathrm{~cm}$ dbh class up to the $90-95 \mathrm{~cm}$ dbh class. Oak had the highest abundance between 45 and $55 \mathrm{~cm}$ dbh (50\% of oak trees) while lime had $25 \%$ of trees in the 30 $35 \mathrm{~cm}$ dbh class and hornbeam trees were most abundant in the $20-25 \mathrm{~cm}$ dbh class ( $24 \%$ of trees).

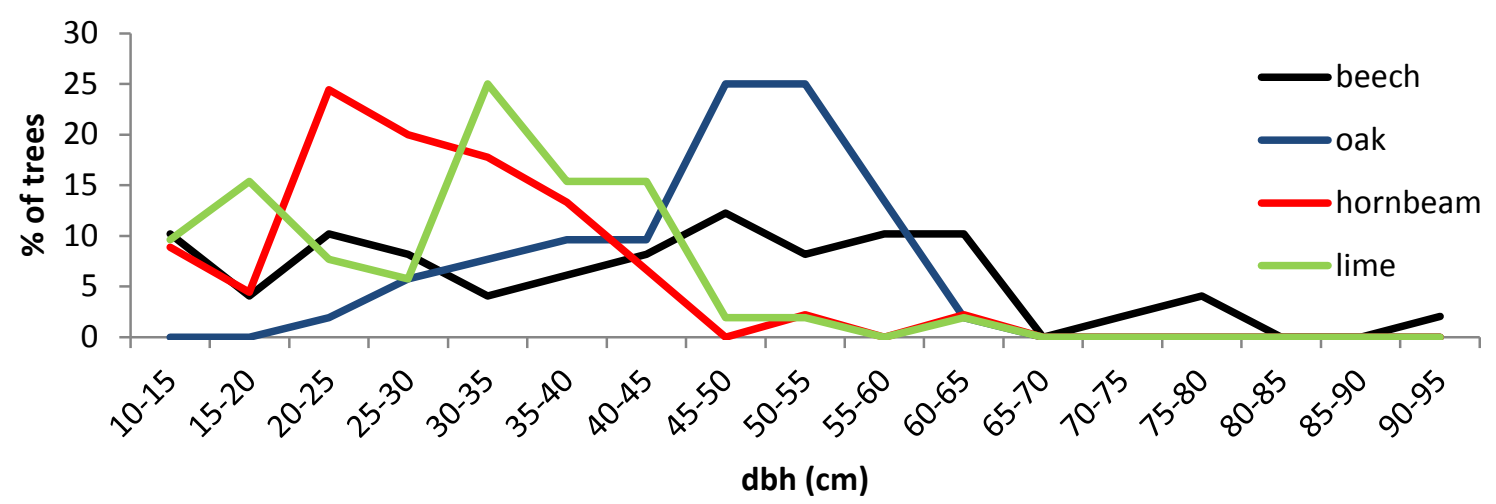

Fig. 3.2: Distribution of diameters at breast-height (dbh) for trees of beech, oak, hornbeam and lime $(n=49$ for beech, $n=52$ for oak, $n=45$ for hornbeam and $n=52$ for lime).

When comparing trees in mono-species stands, $\mathrm{dbh}$ of beech and oak trees were larger than hornbeam and lime $(P<0.01-0.08)$ (Table 3.2). Beech trees also had larger dbh than hornbeam and lime trees when these three species were mixed $(P=0.05-0.08)$ while oak showed larger $\mathrm{dbh}$ than both beech and lime when these species were mixed $(P=0.01-0.02)$. Additionally, in stands containing both oak an hornbeam, oak had larger dbh than hornbeam $(P=0.01-0.02)$. Across all different stands, beech trees were wider when in mono stands than in the beech-oak-lime mix $(P=0.05)$ (Table 3.2). Also, hornbeam trees showed greater $\mathrm{dbh}$ alone compared to in mixures with beech and oak $(P=0.01)$. Oak and lime were not different in $\mathrm{dbh}$ independent of the stand they were located in $(P=0.13-0.26)$.

Growing spaces across all four species increased with increasing dbh $(P<0.01, r=0.31, n=198)$ (Fig. 3.3). This was also found for the individual tree species beech $(P<0.01, r=0.49, \mathrm{n}=50)$, hornbeam $(P=0.04, \mathrm{r}=0.31, \mathrm{n}=45)$ and lime $(P=0.03, \mathrm{r}=0.32, \mathrm{n}=52)$, but not for oak $(P=0.80, \mathrm{r}=0.04, \mathrm{n}=52)$. 
Table 3.2

Mean diameter at breast height within and across stand types at Hainich forest.

\begin{tabular}{|c|c|c|c|c|c|c|}
\hline Stand type and composing species & $\mathrm{n}$ (trees) & $\mathrm{dbh}(\mathrm{SE})$ & $\mathrm{Be}$ & $\mathrm{Oa}$ & $\mathrm{Ho}$ & $\overline{\mathrm{Li}}$ \\
\hline Beech mono (Be) & 25 & $51.1(3.4) \mathrm{a}$ & $A$ & - & - & - \\
\hline Oak mono (Oa) & 24 & $45.0(2.0) \mathrm{a}$ & - & A & - & - \\
\hline Hornbeam mono $(\mathrm{Ho})$ & 25 & $36.3(2.2) b$ & - & - & $A$ & - \\
\hline Lime mono (Li) & 32 & $35.3(2.1) b$ & - & - & - & A \\
\hline \multicolumn{7}{|l|}{ Oak-hornbeam-lime } \\
\hline Oak & 7 & $47.4(2.2) \mathrm{a}$ & - & A & - & - \\
\hline Hornbeam & 11 & $30.0(3.4) b$ & - & - & $A B$ & - \\
\hline Lime & 8 & $37.6(3.2) a b$ & - & - & - & A \\
\hline \multicolumn{7}{|l|}{ Beech-hornbeam-lime } \\
\hline Beech & 8 & $44.7(6.3) \mathrm{a}$ & $A B$ & - & - & - \\
\hline Hornbeam & 8 & $27.5(3.3) b$ & - & - & $A B$ & \\
\hline Lime & 9 & $29.5(4.1) b$ & - & - & - & A \\
\hline \multicolumn{7}{|l|}{ Beech-oak-lime } \\
\hline Beech & 7 & $30.7(5.3) b$ & B & - & - & - \\
\hline Oak & 8 & 53.5 (1.9) a & - & $A$ & - & - \\
\hline Lime & 10 & $31.1(2.9) b$ & - & - & - & A \\
\hline \multicolumn{7}{|l|}{ Beech-oak-hornbeam } \\
\hline Beech & 8 & $37.7(7.4) a b$ & $A B$ & - & - & - \\
\hline Oak & 7 & $48.0(2.5) \mathrm{a}$ & - & $A$ & - & - \\
\hline Hornbeam & 11 & $23.9(2.1) b$ & - & - & B & - \\
\hline
\end{tabular}

Note: Means (SE) with different large letters indicate significant differences for a tree species within different stands. Means (SE) with different small letters indicate significant differences between mono-species stands or between the contributing species of a mix (ANOVA with Tukey HSD test or Kruskal-Wallis test with multiple comparison at $P=0.05$, except between species in mono-species stands as well as species within the beech-hornbeam-lime mix, both where $P=0.08$ ).

\subsubsection{Mean nearest neighbor diameters}

Dbh of a tree and its nearest neighbor (Table 3.3) did not differ for any mono-species pair $(P=$ $0.17-0.80)$. On the other hand, one species of each mixed species pair was in all but two cases larger than the second. Oak had a higher dbh compared to any nearest neighbor $(P<0.01-0.06)$ (Table 3.3). Beech exceeded its nearest neighbors in dbh when the neighbor was hornbeam $(P=0.07)$ or lime $(P=$ $0.06)$, but was smaller than neighboring oak $(P=0.01)$. Lime did not differ in dbh from its nearest 
neighbor when this was beech $(P=0.11)$ or hornbeam $(P=0.69)$, but was smaller than neighboring oak $(P=0.01)$. Hornbeam was smaller than neighboring oak and lime (both $P=0.01$ ). The exceptions with equal size were stands where beech or hornbeam were the nearest neighbor of lime $(P=0.11-0.69)$.

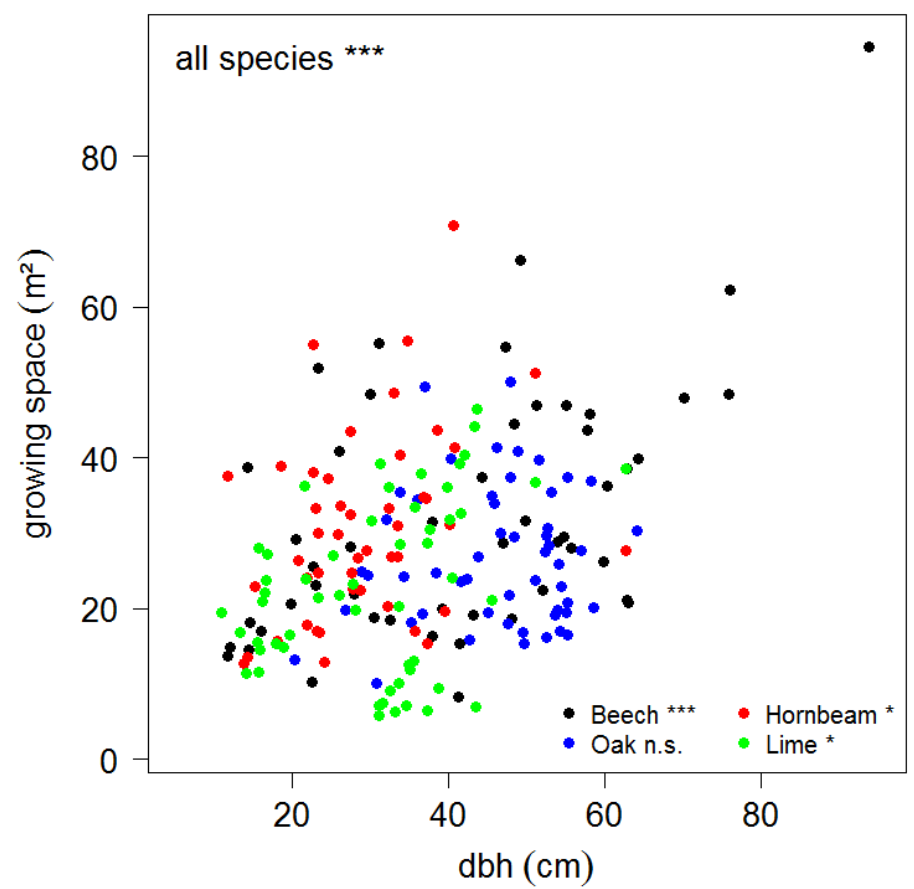

Fig. 3.3: Development of growing space with dbh. Statistics were done with partial Spearman correlations at ${ }^{*} P \leq 0.05,{ }^{* *} P \leq 0.01$ and ${ }^{* * *} P \leq 0.001$.

\subsubsection{Nearest neighbor diameter development}

There were several cases where the $d b h$ of a neighboring tree species responded to increasing $\mathrm{dbh}$ of a target tree species (Fig. 3. 4) - taking into account distance when analyzing dbh of a nearest neighbor. In mono-species pairs, nearest neighbor dbh increased with dbh of the target tree over all species (Fig. 3.4a, $P<0.01$ ), and also for hornbeam bordering on hornbeam $(P=0.08)$. In mixed-species pairs, nearest neighbor dbh decreased with increasing dbh of a targed tree (Fig. 3.4b, $P<0.01$ ). Specifically, dbh of neighboring hornbeam decreased as oak grew and dbh of neighboring lime decreased as hornbeam grew $(P \leq 0.02)$. 


\section{Table 3.3}

Mean nearest neighbor diameters and distances.

\begin{tabular}{|c|c|c|c|c|}
\hline Neighboring sp. & $\mathrm{n}$ & $\mathrm{dbh}$ of $1^{\mathrm{st}}$ species & $\begin{array}{l}\text { dbh of neighboring } \\
\text { species }\end{array}$ & Distance \\
\hline Beech - Beech & 29 & $45.5(3.7) \mathrm{a}$ & $46.9(3.8) \mathrm{a}$ & $3.1(0.3) A B$ \\
\hline Oak - Oak & 26 & $45.6(1.9) \mathrm{a}$ & $48.8(2.2) \mathrm{a}$ & $3.2(0.2) A$ \\
\hline Hornbeam - Hornbeam & 29 & $31.7(1.9) \mathrm{a}$ & $31.9(1.8) \mathrm{a}$ & $3.1(0.2) A B$ \\
\hline Lime - Lime & 35 & $30.1(1.8) \mathrm{a}$ & $26.6(1.6) \mathrm{a}$ & $2.1(0.3) B$ \\
\hline Beech - Oak & 9 & $27.8(4.8) b$ & $51.0(3.6) \mathrm{a}$ & $2.9(0.3) A B$ \\
\hline Oak - Beech & 6 & $49.5(2.9) \mathrm{a}$ & $32.5(7.8) b$ & $2.7(0.3) A B$ \\
\hline Beech - Hornbeam* & 6 & $43.2(7.7) \mathrm{a}$ & $24.8(4.0) b$ & $3.5(0.7) A B$ \\
\hline Beech - Lime & 5 & $52.2(7.8) \mathrm{a}$ & $31.4(5.0) b$ & $3.7(0.7) A B$ \\
\hline Lime - Beech & 5 & $30.6(7.3)$ a & $47.2(5.2) \mathrm{a}$ & $3.2(0.4) A B$ \\
\hline Oak - Hornbeam & 9 & 42.1 (3.9) a & $29.0(2.4) b$ & $3.1(0.3) A B$ \\
\hline Hornbeam - Oak & 6 & $26.9(3.8) b$ & $52.8(4.4) \mathrm{a}$ & $3.8(0.5) A B$ \\
\hline Oak - Lime & 11 & $48.4(2.5) \mathrm{a}$ & $30.9(3.5) b$ & $3.3(0.4) A B$ \\
\hline Lime - Oak & 9 & $29.7(3.4) b$ & $45.2(3.7) \mathrm{a}$ & $2.8(0.2) A B$ \\
\hline Hornbeam - Lime & 9 & $24.7(2.2) b$ & $36.6(3.3)$ a & $3.3(0.4) A B$ \\
\hline Lime - Hornbeam & 3 & $41.2(2.6) \mathrm{a}$ & $35.9(11.5)$ a & $3.3(0.6) A B$ \\
\hline
\end{tabular}

Note: Statistics were done with ANOVA at $P=0.05$, except distances where $P=0.06$, and between species' diameter at breastheight for Beech - Lime and Oak - Beech, where $P=0.06$ and Beech - Hornbeam, where $P=0.07$

* reverse (Hornbeam - Beech) with only one case, therefore no statistical analysis 

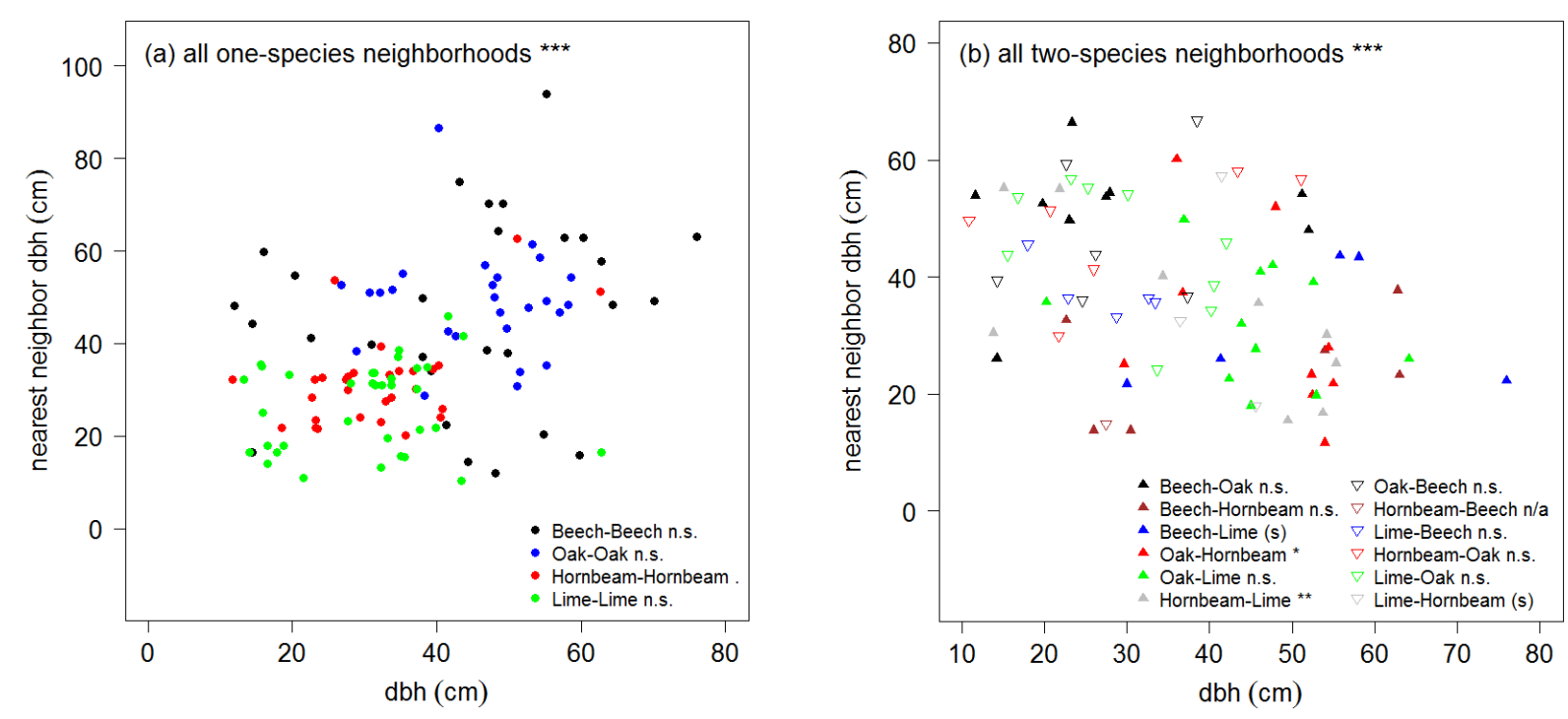

Fig. 3.4: Nearest neighbor dbh for (a) one-species neighborhoods and (b) two-species neighborhoods. Partial spearman correlations at ${ }^{*} P \leq 0.05,{ }^{* *} P \leq 0.01$ and ${ }^{* * *} P \leq 0.001 . \mathrm{n} / \mathrm{a}=$ not available, i.e., only one observation, $(\mathrm{s})=$ singular gradient, which indicates collinearity, i.e., effect of distance and diameter

\subsection{Discussion}

\subsubsection{Competitive order of tree species and the role of oak}

Our results on diameter distribution of the four tree species (Fig. 3.2), indicating differences in the ability of the four species to reach a certain diameter in our forest ecosystem, showed that beech was the most competitive tree species followed by oak $>$ hornbeam $>$ lime. In a study on growthmortality relationships at both Białowieża, Poland, three of our tree species were also present showing that oak was more competitive than hornbeam and lime while in forest reserves in Switzerland the order of peak diameter was similar to our findings (Wunder et al. 2008). However, the presence of other tree species such as F. abies at Białowieża or T. baccata or F. excelsior in Switzerland likely influenced competitive interactions, making comparisons with our study difficult.

When using growing-space analysis, which assumes limitation by nutrients (Mead 1979) or water, as the main criterion, the order of most competitive tree species was beech $>$ hornbeam $=$ lime $>$ oak. However, all species, with the exception of oak, were able to increase growing spaces with time/diameter (Fig. 3.3), and thus potentially increased access to available resources (Firbank and Watkinson 1987). This was most pronounced for beech, since it showed the highest level of significance. 
Nearest neighbor mean diameter analysis, which assumes that light is the limiting resource (Cooper 1961) and includes the asymmetric nature of competition (i.e. the influence of bigger tree is larger than of small ones, Crawley 1990), yielded the order oak $>$ beech $>$ lime $>$ hornbeam (Table 3.3). This order was also supported by our stand type analysis (Table 3.2), with the exception of hornbeam and lime, which did not differ in diameter. Using the development of nearest neighbor diameter, beech could not be included in the order because it did not influence, or was influenced by, the dbh of a neighboring tree. For the other three species, the competitive order was oak > hornbeam > lime; Fig. 3.4b).

In summary, using polygon analysis, we found indications that beech was most successful in competing for below-ground resources like water and nutrients, which is in accordance with our earlier study showing that beech grew faster in mixed species stands compared to mono-species stands (Schmidt et al. 2015). However, oak dominated all other species by diameter (nearest-neighbor analysis) and would thus be a better competitor for light. Oak has also been described as having competitive advantages compared to beech in the dry conditions of the eastern Hainich, where our study site is located (Ellenberg and Leuschner 2010; Nationalparkverwaltung Hainich 2008). These conditions may have made it possible for oak to reach diameters that enable it to successfully compete for light.

However, in our study area, oak contributed only one percent or less of rejuvinating trees (Mölder et al. 2009), furthermore it had the lowest percentage of young trees (Fig. 3.2). This may indicate that oak is a remnant from former forest use (in the past acorns have often been used as feedstuff for pigs) since oak is often dependent on management practices of rejuvination (Bertiller and Müller 2010; Petritan et al 2012). Or, this could be due to combined effects of excess nitrogen deposition and drought stress suggested for $Q$. robur (Thomas et al. 2002). Both aspects may be important. However, less rejuniation nowadays when cultivated pigs are not being fed in the forest together with the competitiveness visible in older trees, speak for a more recent the influence of $\mathrm{N}$ deposition in this dryer eastern part of Hainich (Ellenberg and Leuschner 2010). In sum, even though oak may have played a greater role in the past, as visible from nearest neighbor analysis of now large oak trees, its rejuvination is low, enabling beech to become the single most dominant species in our forest ecosystem.

\subsubsection{Intra- vs. interspecific competition}

Our findings that in intraspecific nearest-neighborhoods, dbh of the neighbor increased (Fig. 3.4a) and no size difference in neighbors for intraspecific nearest-neighborhoods (Table 3.3), indicate mutual growth and a similar age structure of neighboring trees of the same species. Such a segregating 
behavior has been described e.g. for red cedar on Vancouver Island (Getzin et al. 2006). In contrast, when conducting interspecific nearest-neighborhoods analysis, neighborhood-dbh decreased (Fig. 3.4b) and we found dbh-differences of neighbors for interspecific nearest-neighbors, which suggests asymmetric competition, i.e., an advantage for the larger tree (Crawley 1990) (Table 3.3). This illustrated that competition in mono-species stands was not stronger than competition in interspecific stands (Röhrig et al. 2006; Begon et al. 2006). This was also supported by the higher above-ground woody biomass of beech, oak and lime in mono-species stands suggesting stronger interspecific competition compared to intraspecific competition (Table 3.1). In our previous study at the same site (Schmidt et al. 2015), lime grew faster among lime and the success of beech in interspecific neighborhoods could be attributed to higher nutrient availability. If, additionally, interspecific competition declines with stand age due to greater space between trees and niche occupation (Getzin et al. 2006), this poses another advantage for the older mono-species stands over their adjacent younger mixed stands in the studied forest. These results are in contrast to a study in temperate deciduous forest in Spain, where interspecific competition was small, resulting in small, multi-species clumps (Martinez et al. 2010) and a study in German forests that found strong intraspecific competition through terrestrial laser scanning of tree crowns (Metz et al. 2013).

In summary, in our unmanaged forest we detected little intraspecific competition and strong interspecific competition which supports the theory that interspecific competition is more important for population dynamics than intraspecific competition (Crawley 1990). Although nearest-neighbor analysis has been criticized since it ignores interactions further away than the nearest neighbor (Moeur 1993), our analysis showed that it reveals important interaction that occur between neighboring tree species.

\subsubsection{Stand development with time}

The mean above-ground woody biomass of $440 \mathrm{t} \mathrm{ha}^{-1}$ in our study was high compared to other studies. In a study comparing 36 temperate forest sites in Central Europe (range of 169 to $536 \mathrm{t} \mathrm{ha}^{-1}$ ), only two sites showed higher above-ground woody biomass (Szwagrzyk and Gazda 2007). If we assume that the stands with different tree compositions reflect different stages of stand development, stands that have low above-ground woody biomass would represent early stages of development while stands with higher biomass would characterize later stages of development (Emborg et al. 2000). Accordingly, mono-species stands of hornbeam which had the lowest overall above-ground biomass appear to be in early stages of stand development (Table 3.1). In a study in a national park in Poland a high abundance of hornbeam was attributed to frequent natural disturbances (Szwagrzyk et al. 2012). For our study this 
suggests that hornbeam plays an important role as a pioneer in our studied forest. At a later development stage hornbeam is replaced by hornbeam-lime mixtures, followed by beech-oak mixtures. Mono-species stands of lime, oak and beech appear to make up the climax formations in this unmanaged temperate deciduous forest since they have the highest above-ground woody biomass. Both beech an oak may create conditions that are favorable for their respective saplings: patches of mature beech , create a shaded environment which gives beech saplings an advantage compared to other tree species (von Wuelisch 2008) while patches of mature oaks have a relatively open crown which is more favorable for oak saplings (Ellenberg and Leuschner 2010). A patchy mosaic was also found for oak in an oldgrowth forest with beech dominance in western Romania (Petritan et al. 2012).

Mixed-beech forests are heterogeneous in space and time and will probably not move towards beech dominance (Closset-Kopp et al. 2006). Also, small scale variability in soil conditions (Schmidt et al. 2015) and heterogeneous environmental parameters influence species composition (Ellenberg and Leuschner 2010). Furthermore, whenever large trees - using a growing space of about $1 \mathrm{~m}^{2}$ per $1 \mathrm{~cm} d b h$ (estimated from Fig. 3.3) - die and form a gap, this room can immediately be occupied by smaller, earlysuccessional trees as was the case with hornbeam in our study. In summary, our observations support our hypothesis that species compositions at our study site represent stages in long-term stand development. Mean diameter values within stand types and statistics presented in Table 3.2 may be useful as a reference in forest management since they display which diameters for species can be expected in a forests under comparable environmental conditions and with similar species composition.

\subsection{Conclusions}

The analysis of nearest neighbors and growing spaces gave insight into below-ground competitiveness of beech and above-ground competitiveness of oak. Although the remaining oak trees were most competitive for light, oak rejuvination was limited, which will make beech the dominant tree species in the future. We found strong interspecific competition which contrasted with weak intraspecific competition. This seems to be one of the main reasons why this forests has developed into a pattern of mature one-species patches (of beech, oak and lime); one-species patches of pioneer trees (hornbeam) as well as patches of mixed-species at intermediate stages of development. 


\section{Acknowledgements}

We would like to thank the DFG for funding this research. Thank you to Johannes Persch and Frederic Fischer, who wrote their Bachelor-theses in the framework of our project. We also thank the national park authorities for allowing this research.

\section{References}

Backes, K., Leuschner, C., 2000. Leaf water relations of competitive Fagus sylvatica and Quercus petraea trees during 4 years differing in soil drought. Can. J. For. Res. 30, 335-346. doi:10.1139/x99-205

Begon, M., Townsend, C.R., Harper, J.L., 2006 Ecology: From Individuals to Ecosystems, 4th Edition. ed. Blackwell Publishing.

Bertiller R., Müller R. 2010: Biodiversität im Eichenwald. proQuercus. Merkblatt 5.

Bohn, U.; Gollub, G. \& Hettwer, C., 2000. Map of the Natural Vegetation of Europe. Scale 1:2.500.000. Part 2: Legend and Part 3: Maps. Münster, Germany.

Bunce, R. G. H., 1968. Biomass and production of trees in a mixed deciduous woodland: I. Girth and height as parameters for the estimation of tree dry weight. The Journal of Ecology 56, 759-775.

Burrascano, S., Lombardi, F., Marchetti, M., 2008. Old-growth forest structure and deadwood: Are they indicators of plant species composition? A case study from central Italy. Plant Biosystems 142, 313-323. doi:10.1080/11263500802150613

Cienciala, E., Apltauer, J., Exnerová, Z., Tatarinov, F., 2008. Biomass functions applicable to oak trees grown in Central-European forestry. Journal of Forest Science 54, 109-120.

Clark, P.J., Evans, F.C., 1954. Distance to Nearest Neighbor as a Measure of Spatial Relationships in Populations. Ecology 35, 445-453. doi:10.2307/1931034

Closset-Kopp, D., Schnitzler, A., \& Aran, D. (2006). Dynamics in natural mixed-beech forest of the Upper Vosges, in: Hawksworth, David L., Bull, Alan T. (Eds.), Forest Diversity and Management. Springer Netherlands, pp. 333.

Cooper, C.F., 1961. Pattern in Ponderosa Pine Forests. Ecology 42, 493-499. doi:10.2307/1932235

Commarmot, B., Bachofen, H., Bundziak, Y., Bürgi, A., Ramp, B., Shparyk, Y., Sukhariuk, D., Viter, R., Zingg, A., 2005. Structures of virgin and managed beech forests in Uholka (Ukraine) and Sihlwald (Switzerland): a comparative study. Forest Snow and Landscape Research 79, 45-56.

Crawley, M.J., 1990.The population dynamics of plants. Philosophical Transactions of the Royal Society B: Biological Sciences 330.1257, 125-140.

Crawley, M.J., 1997. Life History and Environment, in: Crawley, M.J. (Ed.), Plant Ecology. Blackwell Publishing Ltd., pp. 73-131.

Ellenberg, H., Leuschner, C., 2010. Vegetation Mitteleuropas mit den Alpen: In ökologischer, dynamischer und historischer Sicht, UTB, Stuttgart. 
Emborg, J., Christensen, M., Heilmann-Clausen, J., 2000. The structural dynamics of Suserup Skov, a near-natural temperate deciduous forest in Denmark. Forest Ecology and Management 126, 173-189. doi:10.1016/S0378-1127(99)00094-8

Firbank, L.G., Watkinson, A.R., 1987. On the analysis of competition at the level of the individual plant. Oecologia 71, 308-317. doi:10.1007/BF00377300

Fischer, F., 2013. Untersuchung oberirdischer Biomasse bei unterschiedlicher Baumartenzusammensetzung im Nationalpark Hainich. BSc Thesis, University of Göttingen.

Fox, J., Weisberg, S., 2011. An \{R\} Companion to Applied Regression, Second Edition. Thousand Oaks, CA: Sage. http://socserv.socsci.mcmaster.ca/jfox/Books/Companion

Getzin, S., Dean, C., He, F., A. Trofymow, J., Wiegand, K., Wiegand, T., 2006. Spatial patterns and competition of tree species in a Douglas-fir chronosequence on Vancouver Island. Ecography 29, 671-682. doi:10.1111/j.2006.0906-7590.04675.x

Giraudoux, P., 2014. pgirmess: Data analysis in ecology. R package version 1.5.9. http://CRAN.Rproject.org/package=pgirmess

Hothorn, T., Bretz, F., Westfall, P., 2008. Simultaneous Inference in General Parametric Models. Biometrical Journal 50, 346-363.

Kim, S. (2012). ppcor: Partial and Semi-partial (Part) correlation. R package version 1.0. http://CRAN.Rproject.org/package=ppcor

Leuschner, C., Meier, I. C., Hertel, D., 2006. On the niche breadth of Fagus sylvatica: soil nutrient status in 50 Central European beech stands on a broad range of bedrock types. Annals of Forest Science 63, 355-368.

Luyssaert, S., Schulze, E.-D., Börner, A., Knohl, A., Hessenmöller, D., Law, B.E., Ciais, P., Grace, J., 2008. Old-growth forests as global carbon sinks. Nature 455, 213-215. doi:10.1038/nature07276

Martínez, I., Wiegand, T., González-Taboada, F., Obeso, J.R., 2010. Spatial associations among tree species in a temperate forest community in North-western Spain. Forest Ecology and Management 260, 456-465. doi:10.1016/j.foreco.2010.04.039

Mead, R., 1966. A Relationship Between Individual Plant-Spacing and Yield. Annals of Botany 30, 301-309.

Mead, R., 1979. Competition Experiments. Biometrics 35, 41-54. doi:10.2307/2529935

Meier, I.C., Leuschner, C., Hertel, D., 2005. Leaf litter nutrients with leaf litter fall in Fagus sylvatica forests across a soil fertility gradient. Plant Ecology 177, 99-112. doi:10.1007/s11258-005-2221-z

Metz, J., Seidel, D., Schall, P., Scheffer, D., Schulze, E.-D., Ammer, C., 2013. Crown modeling by terrestrial laser scanning as an approach to assess the effect of aboveground intra- and interspecific competition on tree growth. Forest Ecology and Management 310, 275-288. doi:10.1016/j.foreco.2013.08.014

Moeur, M., 1993. Characterizing Spatial Patterns of Trees Using Stem-Mapped Data. Forest Science 39, 756-775.

Nakashizuka, T., 2001. Species coexistence in temperate, mixed deciduous forests. Trends in Ecology \& Evolution 16, 205-210. doi:10.1016/S0169-5347(01)02117-6

Nationalparkverwaltung Hainich, 2008. Wälder im Nationalpark Hainich. Ergebnisse der 1. permanenten Stichprobeninventur 1999-2001. Erforschen Band 1. Nationalparkverwaltung Hainich. Bad Langensalza, Germany.

Oszako, T., 1997. Oak decline in European forests. First EUFORGEN Meeting on Social Broadleaves 145-151.

Persch, J., 2013. Deduction of potential growing spaces for various compositions of tree species in the Nationalpark Hainich. BSc Thesis, University of Göttingen.

Petritan, A.M., Biris, I.A., Merce, O., Turcu, D.O., Petritan, I.C., 2012. Structure and diversity of a natural temperate sessile oak (Quercus petraea L.) - European Beech (Fagus sylvatica L.) forest. Forest Ecology and Management 280, 140-149. doi:10.1016/j.foreco.2012.06.007 
Petritan, I.C., Marzano, R., Petritan, A.M., Lingua, E., 2014. Overstory succession in a mixed Quercus petraea-Fagus sylvatica old growth forest revealed through the spatial pattern of competition and mortality. Forest Ecology and Management 326, 9-17. doi:10.1016/j.foreco.2014.04.017

Pickett, S.T.A., 1989. Space-for-Time Substitution as an Alternative to Long-Term Studies, in: Likens, G.E. (Ed.), LongTerm Studies in Ecology. Springer New York, pp. 110-135.

Pretzsch, H., 2009. Forest dynamics, growth, and yield. Springer. Berlin, Heidelberg.

Rajendra, K. C., 2009. Species identification in Tilia: a genetic approach, M. Sc. thesis. Georg-August-University, Göttingen, Germany.

Rohner, B., Bigler, C., Wunder, J., Brang, P., Bugmann, H., 2012. Fifty years of natural succession in Swiss forest reserves: changes in stand structure and mortality rates of oak and beech. J Veg Sci 23, 892-905. doi:10.1111/j.1654-1103.2012.01408.x

Röhrig, E., Bartsch, N., Lüpke, B. von, Dengler, A., 2006. Waldbau auf ökologischer Grundlage. Ulmer.

Schmidt, M., Veldkamp, E., Corre, M.D., 2015. Tree species diversity effects on productivity, soil nutrient availability and nutrient response efficiency in a temperate deciduous forest. Forest Ecology and Management 338, 114-123. doi:10.1016/j.foreco.2014.11.021

Şen, Z., 2009. Spatial Modeling Principles in Earth Sciences, 2009 edition. Springer, Dordrecht ; London.

Szwagrzyk, J., Gazda, A., 2007. Above-ground standing biomass and tree species diversity in natural stands of Central Europe. Journal of Vegetation Science 18, 555-562. doi:10.1111/j.1654-1103.2007.tb02569.x

Szwagrzyk, J., Szewczyk, J., Maciejewski, Z., 2012. Shade-tolerant tree species from temperate forests differ in their competitive abilities: A case study from Roztocze, south-eastern Poland. Forest Ecology and Management 282, 28-35. doi:10.1016/j.foreco.2012.06.031

Thomas, F.M., Blank, R., Hartmann, G., 2002. Abiotic and biotic factors and their interactions as causes of oak decline in Central Europe. Forest Pathology 32, 277-307. doi:10.1046/j.1439-0329.2002.00291.x

Tomé, M., Burkhart, H.E., 1989. Distance-Dependent Competition Measures for Predicting Growth of Individual Trees. Forest Science 35, 816-831.

QGIS Development Team, 2012. QGIS Geographic Information System. Open Source Geospatial Foundation Project. http://qgis.osgeo.org

R Development Core Team, 2013. R: A language and environment for statistical computing. R Foundation for Statistical Computing, Vienna, Austria. http://www.r-project.org.

von Wuehlisch G. 2008. EUFORGEN Technical Guidelines for genetic conservation and use for European beech (Fagus sylvatica). Bioversity International, Rome, Italy. 6 pages.

Weiskittel, A.R., Hann, D.W., Kershaw Jr, J.A., Vanclay, J.K., 2011. Forest growth and yield modeling. John Wiley \& Sons.

Wirth, C., Schulze, E. D., Schwalbe, G., Tomczyk, S., Weber, G., Weller, E., 2004. Dynamik der Kohlenstoffvorräte in den Wäldern Thüringens. Mitteilungen 23/2004. Thüringer Ministerium für Landwirtschaft Naturschutz und Umwelt. Erfurt, Germany.

Wunder, J., Brzeziecki, B., Żybura, H., Reineking, B., Bigler, C., Bugmann, H., 2008. Growth-mortality relationships as indicators of life-history strategies: a comparison of nine tree species in unmanaged European forests. Oikos 117, 815-828. doi:10.1111/j.0030-1299.2008.16371.x

York, R.A., O’Hara, K.L., Battles, J.J., 2013. Density Effects on Giant Sequoia (Sequoiadendron giganteum) Growth Through 22 Years: Implications for Restoration and Plantation Management. Western Journal of Applied Forestry 28, 30-36. doi:10.5849/wjaf.12-017 
Synthesis 


\section{Synthesis}

Several key conclusions can be drawn from this work:

1. Phosphorus $(P)$ and potassium (K), limited forest productivity, but only in mono-species stands of beech (Chapters 1 and 2). The productivity of beech trees responded to both increased levels of available $\mathrm{P}$ and exchangeable $\mathrm{K}$, leading to optimum $\mathrm{P}$ and $\mathrm{K}$ response efficiencies (biomass production per available nutrient, Bridgham et al. 1995) and thus facilitation of beech trees in mix-species stands. This was also reflected in higher sunlit-leaf P concentrations when beech was mixed with lime. Increased availability of $\mathrm{P}$ and $\mathrm{K}$ could be attributed to increased annual net $\mathrm{P}$ and $\mathrm{K}$ change in decomposing leaf litter of mixed-species stands, which were not limited by any nutrient.

2. Effects of mixing were largely species-related (Chapters 1 and 2). With the exception of facilitation in the growth of beech, we found no indication for species diversity effects. Both productivity and nutrient availability at stand level could be attributed to the tree species which contributed to the mix. Also, decomposition rates were determined by the tree species present, as were nutrient retention and annual net nutrient change.

\section{Tree-microbial biomass competition for $P$ and $K$ was important on ecosystem level (Chapters 1}

and 2). Low annual net nutrient change decreased the availability of $P$ and $K$ in the soil, which in turn limited the growth of beech. These results, combined with a negative response of nutrient resorption efficiency to annual net nutrient change in decomposing leaf litter (largely controlled by microbial biomass, Singh and Gupta 1977), strongly indicated competition between trees and microbes for P and K. This resorption efficiency-nutrient change relationship was observed across species compositions, stressing its importance on ecosystem level.

\section{Neighborhood dynamics and stand development were controlled by strong interspecific} competition (Chapter 3). Interspecific neighborhoods were characterized by decreasing nearest neighbor diameter with as the target tree diameter increased - as well as differences in nearest neighbor diameter and thus competition from larger to smaller tree (Crawley 1990). In contrast, intraspecific neighbors were of the same diameter and both increased diameter with time, showing mutual growth. Strong interspecific competition in beech, oak and lime was also supported by smaller stand biomass of 
younger mixed stands compared to higher stand biomass in older mono-species stands. Hornbeam stands took a pioneer role. Stands of different composition may represent stages in stand development.

5. High nitrogen ( $N$ ) deposition affected nutritional and structural dynamics (Chapters 1, 2 and 3 ). High atmospheric $\mathrm{N}$ deposition (Builtjes et al. 2011) has likely caused a decoupling of the internal $\mathrm{N}$ cycle between annual net nutrient change in decomposing leaf litter and soil $\mathrm{N}$ availability. Through a negative influence on plant-mycorrhizal association (Braun et al., 2010), foliar P concentrations in central Europe have decreased (Talkner et al. 2015). Aside from K, we found $\mathrm{P}$ and not $\mathrm{N}$ (limiting in unpolluted temperate and boreal forests (Vitousek 1982; Hedin et al. 1995)) to be limiting so that P may have replaced $\mathrm{N}$ as a growth-limiting nutrient in our ecosystem. Such change has certainly caused shifts in the associated dynamics, namely the growth of beech in mixed stands as well as tree-microbial biomass competition. Furthermore, oak decline has been suggested to be in part caused by excess nitrogen (Thomas et al. 2002), putting beech in advantage at eastern Hainich where it would otherwise potentially be outcompeted by oak (Ellenberg and Leuschner 2010).

6. Implications for forest management (Chapters 1, 2 and 3). A strong influence of trees by their direct neighbor, i.e., higher growth of beech when combined with hornbeam and/or lime as well as higher growth of lime when growing among lime, implies that forest management may profit by including these considerations in practice. Mixed stands also seem to pose a reduced risk of nutrient limitation for tree species with slow nutrient turnover. For beech, optimum growth and, in the end, highest standing biomass can be achieved when it naturally passes through a mixed phase and later becomes dominant.

7. Outlook. Nutrient response efficiency and the neighborhood approach are useful methods, because they yield information on nutrient/resource limitations, the effects of species mixing and the resulting productivity. For theoretical considerations as well as forest applications, it would be of great interest to see how combined response efficiency curves of several species limited by (or saturated with) several resources predict forest productivity - and how these curves change due to shifting limitations connected to global change. 


\section{References}

Bridgham, S. D., Pastor, J., McClaugherty, C. A., Richardson, C. J., 1995. Nutrient-use efficiency: a litterfall index, a model, and a test along a nutrient-availability gradient in North Carolina peatlands. American Naturalist $145,1-21$.

Braun, S., Thomas, V.F.D., Quiring, R., Flueckiger, W., 2010. Does nitrogen deposition increase forest production? The role of phosphorus. Environmental Pollution 158, 2043-2052. doi:10.1016/j.envpol.2009.11.030

Builtjes, P., Hendriks, E., Koenen, M., Schaap, M., Banzhaf, S., Kerschbaumer, A. Gauger, T., Nagel, H.D. Scheuschner, T., Schlutow, A., 2011. Erfassung, Prognose und Bewertung von Stoffeinträgen und ihren Wirkungen in Deutschland-Zusammenfassender Abschlussbericht. Umweltbundesamt. Dessau-Rosslau, Germany. Appendix 11.

Crawley, M.J., 1990.The population dynamics of plants. Philosophical Transactions of the Royal Society B: Biological Sciences 330.1257, 125-140.

Ellenberg, H., Leuschner, C., 2010. Vegetation Mitteleuropas mit den Alpen: In ökologischer, dynamischer und historischer Sicht, UTB, Stuttgart.

Hedin, L. O., Armesto, J. J., Johnson, A. H., 1995. Patterns of nutrient loss from unpolluted, old-growth temperate forests: evaluation of biogeochemical theory. Ecology 76, 493-509.

Singh, J., Gupta, S., 1977. Plant Decomposition and Soil Respiration in Terrestrial Ecosystems. Botanical Review 43, 499-528.

Talkner, U., Meiwes, K.J., Potočić, N., Seletković, I., Cools, N., Vos, B.D., Rautio, P., 2015. Phosphorus nutrition of beech (Fagus sylvatica L.) is decreasing in Europe. Annals of Forest Science 1-10. doi:10.1007/s13595-0150459-8

Thomas, F.M., Blank, R., Hartmann, G., 2002. Abiotic and biotic factors and their interactions as causes of oak decline in Central Europe. Forest Pathology 32, 277-307. doi:10.1046/j.1439-0329.2002.00291.x

Vitousek, P., 1982. Nutrient cycling and nutrient use efficiency. American Naturalist 119, 553-572. 


\section{Danksagung}

Viele Menschen und Organisationen haben zu dieser Arbeit und meiner Zeit als Doktorand direkt und indirekt beigetragen. Die DFG (GRK 1086, Unterprojekt B7) hat mit ihrem Stipendium die Arbeit erst ermöglicht und der Nationalpark Hainich das Untersuchungsgebiet für unsere Forschungen zur Verfügung gestellt.

Während der Arbeit wurde ich von vielen Mitarbeitern mit Ratschlägen und/oder praktischer Hilfe unterstützt. Danke an Andrea, Dirk, Kerstin, Karin, Martina ${ }^{2}$, Anita, Heike und Susann.

Für die wissenschaftliche Gespräche und nette Gesellschaft danke ich Andreas, Marleen, Oliver, Evelyn, Syahrul, Yuan, Per, Armando, lan, Anke, Katrin, Martin, Norman, Hubert, Falk, Paul, Anna, Linda und Holger, Fei und Kara.

Weiterhing danke ich den Studenten Frederic Fischer, Johannes Persch und Wiebke Schrell für ihren Beitrag zu diesem Projekt mit der Durchführung ihre Bachelor-Arbeiten.

Ein besonderer Dank gilt meinen Betreuern Edzo Veldkamp und Marife Corre für die kontinuierliche Unterstützung, die wertvollen Fragen, ihre Kommentare und Ideen. Sie haben mich angeregt, immer tiefer zu hinterfragen und mich stetig zu entwickeln.

Tiefer Dank gilt meinem Bruder, der mir die Naturwissenschaften vorgelebt hat, meinem Vater, der mir beigebracht hat nie aufzugeben und immer noch ein bisschen besser zu werden und meiner Mutter, weil sie immer für mich da war.

Last but not least danke ich meiner Frau Kathi, die mir im Wald, bei meiner Arbeit und generell immer eine liebevolle Stütze war. Und meinen drei wundervollen Kindern, die mich all die wunderbaren Dinge neben der Wissenschaft nie vergessen lassen. 
100 


\section{Curriculum Vitae}

Marcus Schmidt, geboren am11. Juli 1984 in Suhl

Staatsangehörigkeit: Deutsch

\section{Bildungsweg}

seit 10/2011 Promotionsstudium Forstwissenschaften und Waldökologie,

Georg-August Universität Göttingen

2011 Diplom in Geographie, Universität Leipzig,

Nebenfächer Biologie und Geowissenschaften (10/2005 - 05/2011)

2004

Abitur, Goethe-Gymnasium Ilmenau

\section{Publikationen}

Schmidt, M., Veldkamp, E., Corre, M.D., 2015. Tree species diversity effects on productivity, soil nutrient availability and nutrient response efficiency in a temperate deciduous forest. Forest Ecology and Management 338, 118-123. http://dx.doi.org/10.1016/j.foreco.2014.11.021

Schmidt, M., 2014. Book review: Water Resilience for Human Prosperity. GeoQ. The quarterly newsletter of the European Geosciences Union. http://www.egu.eu/newsletter/geoq/12.pdf

\section{Vorträge und Posterpräsentationen}

Schmidt, M., Veldkamp, E. \& Corre, M.D, (2014): Biodiversity effects on nutrient response efficiency in a temperate forest. BIOGEOMON 2014, Bayreuth. Posterpräsentation - 07/2014

Schmidt, M. (2014): Einfluss von Biodiversitätseffekten auf Produktivität, Nährstoffverfügbarkeit und Nährstoffnutzungseffizienz im Hainich Nationalpark. Workshop des AK Waldökologie der GfÖ. Göttingen. Vortrag - 04/2014 
Schmidt, M., Veldkamp, E. \& Corre, M.D, (2013): Nitrogen response efficiency of Fagus sylvatica and Tilia spp. in natural mono and mix compositions. AT: INTECOL 2013, London. Posterpräsentation $08 / 2013$

Suchodoletz, H.v., Herrmann, M., Schmidt, M. \& C. Zielhofer (2011): Tracking and quantifying recent soil erosion in a semi-arid catchment area at Lanzarote (Canary Island). European Geosciences Union (EGU) 2011, Vienna. Posterpräsentation - 04/2011 